NBSIR 84-2911

\title{
National Bureau of Standards Passive Solar Test Facility - Instrumentation and Site Handbook
}

U.S. DEPARTMENT OF COMMERCE

National Bureau of Standards

National Engineering Laboratory

Center for Building Technology

Building Equipment Division

Gaithersburg, MD 20899

June 1984

Issued August 1984

Prepared for:

U.S. Department of Energy

Office of Solar Heat Technologies

QC

100

.456

Passive and Hydrid Solar Energy Division Experimental System Research Program

Washington, DC 20585

no. $84-2911$

1984

C. 2 

NATIONAL BUREAU OF STANDARDS

PASSIVE SOLAR TEST FACILITY -

INSTRUMENTATION AND SITE

HANDBOOK

Bal M. Mahajan

U.S. DEPARTMENT OF COMMERCE

National Bureau of Standards

National Engineering Laboratory

Center for Building Technology

Building Equipment Division

Gaithersburg, MD 20899

June 1984

Issued August 1984

Prepared for:

U.S. Department of Energy

Office of Solar Heat Technologies

Passive and Hydrid Solar Energy Division

Experimental System Research Program

Washington, DC 20585

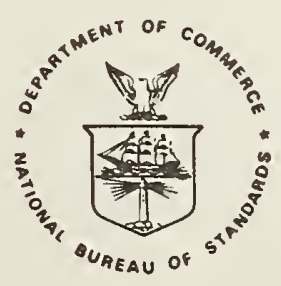

U.S. DEPARTMENT OF COMMERCE, Malcolm Baldrige, Secretary NATIONAL BUREAU OF STANDARDS, Ernest Ambler, Director 



\section{ABSTRACT}

The National Bureau of Standards (NBS), under the sponsorship of the U.S. Department of Energy (DOE) has constructed a passive solar test facility. As a part of the DOE's Experimental Systems Research Program, the NBS test facility has been constructed for the purpose of acquiring and distributing to participating researchers class A level performance data for different passive systems. These data are acquired for use in: detailed building energy analysis and model/algorithm validation; and performance characterization of passive subsystems.

This handbook provides a complete description of the test building, thermophysical properties of the building material, location of the sensors installed at the test facility, and data acquisition system and procedures. 


\section{NOTES FOR THE FIGURES}

1. All dimensions shown in the figures are nominal.

2. The test facility was constructed using the nominal dimensions in English Units. Expression of the dimension in Metric Units would suggest inordinately small dimensional tolerances. Hence the dimensions are shown in English Units. For the convenience of the readers, the Metric equivalent of English Units are given below.

1 foot $=0.3048$ meter

1 inch $=0.0254$ meter 
1. INTRODUCTION $\ldots \ldots \ldots \ldots \ldots \ldots \ldots \ldots \ldots \ldots \ldots \ldots \ldots \ldots \ldots \ldots \ldots \ldots \ldots \ldots \ldots \ldots \ldots \ldots \ldots$

2. GENERAL ENVIRONMENTS ................................. 3

3. DESCRIPTION OF THE BUILDING $\ldots \ldots \ldots \ldots \ldots \ldots \ldots \ldots \ldots \ldots \ldots \ldots \ldots \ldots \ldots \ldots \ldots \ldots \ldots \ldots$

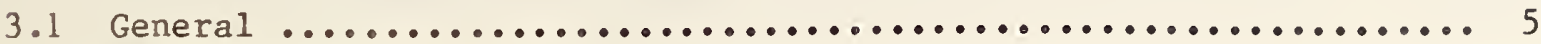

3.2 Celing/Roof $\ldots \ldots \ldots \ldots \ldots \ldots \ldots \ldots \ldots \ldots \ldots \ldots \ldots \ldots \ldots \ldots \ldots \ldots \ldots \ldots$

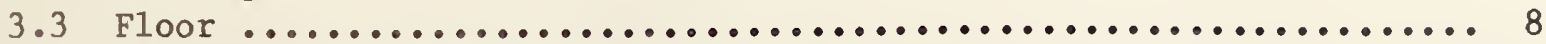

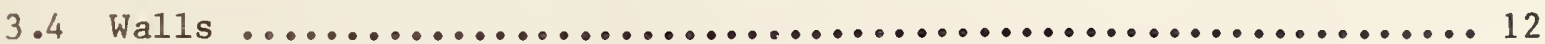

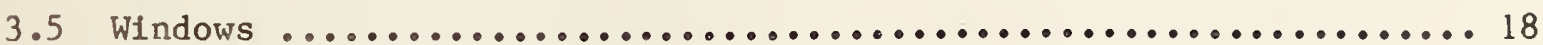

3.6 Individual Cells .................................. 18

3.7 Material properties and Heat Loss Coefficient of Test Cells ..... 33

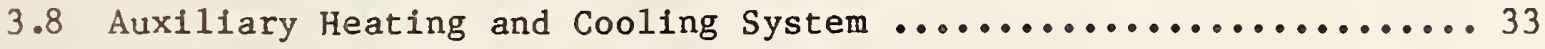

4. INTRUMENTATION ..................................... 37

4.1 Outside $\ldots \ldots \ldots \ldots \ldots \ldots \ldots \ldots \ldots \ldots \ldots \ldots \ldots \ldots \ldots \ldots \ldots \ldots \ldots \ldots \ldots \ldots \ldots \ldots \ldots \ldots \ldots$

$4.2 \quad \operatorname{Ce} 11$ \#1 $\ldots \ldots \ldots \ldots \ldots \ldots \ldots \ldots \ldots \ldots \ldots \ldots \ldots \ldots \ldots \ldots \ldots \ldots \ldots \ldots \ldots \ldots \ldots \ldots \ldots \ldots \ldots$

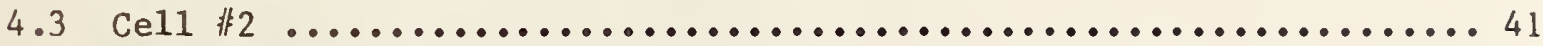

4.4 Ce11 $\|_{3} 3 \ldots \ldots \ldots \ldots \ldots \ldots \ldots \ldots \ldots \ldots \ldots \ldots \ldots \ldots \ldots \ldots \ldots \ldots \ldots \ldots \ldots \ldots \ldots \ldots \ldots \ldots \ldots 48$

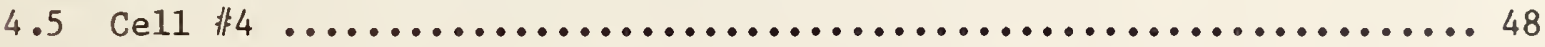

5. DATA ACQUISITION AND DISTRIBUTION ....................... 58

5.1 Data Acquisition System .......................... 58

5.2 Continuous Air Infiltration Monitoring system ............. 58

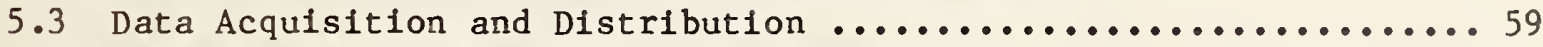

5.4 Estimates of Uncertainty in the Measured Data .............. 59

6. CONCLUDING REMARKS .................................. 63

7. ACKNOWLEDGEMENT ...................................... 63

8. REFERENCES ............................................. 64

8. APPENDIX A. A Copy of Data Documentation ................... 66 



\section{INTRODUCTION}

In 1980, the U.S. Department of Energy established a Program Area Plan for systematic performance evaluation of passive/hybrid heating and cooling systems $[1,2]$. This program area plan defines three levels of performance monitoring procedures which, in decreasing order of sophistication, have been designated as Class A, B, and C. Both class A and class B level monitoring involved fixed instrumentation and data acquisition equipment, while class $C$ level monftoring involves simple hand-recorded measurements and surveys of occupant reactions.

Class B level monitoring provides limited detailed data (about 20 sensors per building) from occupied buildings for field testing and statistical evaluation of passive systems and buildings. Class A level monitoring is defined to provide carefully measured detailed data (about 200 sensors per building) under controlled conditions for use in (1) detailed building energy analysis and model/algorithm validation; and (2) performance characterization of various passive subsystems.

The National Bureau of Standards (NBS), under the sponsorship of DoE, has constructed a full-scale four-cell passive solar test facility. The test facility contains several types of generic passive solar features such as a direct gain system, a collector storage wall (Trombe wall), and clerestory windows. The NBS test facility has been constructed as a part of the DoE's Experimental Systems Research Program and is used for acquiring and distributing to participating researchers class A level performance data for various passive subsystems under different experimental conditions. The purpose of this handbook is to provide to the data users (i.e. models, algorithms developer/validators) a complete physical description of the test building as well as the location of sensors used for gathering data.

The test facility was made operational in October of 1981 , with the direct gain cell completely instrumented and the other cells minimally instrumented. A handbook describing the NBS test facility, thermophysical properties of construction materials, and sensor locations was published and distributed [3]. During FY82 performance data from the direct gain cell, under three different experimental conditions, were collected and distributed to the participating researchers. A technical paper containing the representative results from these data was presented at the ASME Passive Solar Division S1xth Annual Technical Conference in April 1983 [4].

In FY83 instrumentation of the Trombe wall cell was completed. A new data acquisition system (DAS) and a multichannel continuous air infiltration monitoring system (CAIMS) were procured and installed at the test facility. During FY83 some experiments were conducted to monitor the performance of the direct gain and Trombe wall cells, and to measure the thermocirculation characteristics of the Trombe wall. A paper containing a brief description of the new DAS and CAIMS, and some representative results from the FY83 experimental work was presented at the Passive and Hybrid Solar Energy Update meeting 1n September 1983 [5]. The data tape containing the hourly average data set was distributed 
to the participating researchers. In the beginning of FY84 some additional thermocouples were installed in the direct gain cell (cell 非) and the control cell ( $\operatorname{cell}$ 非).

This handbook contains a complete physical description of the test facility, as well as the thermophysical properties of the building materials and building components. The handbook contains a complete directory (type and location) of the sensors installed in and around the building, and a brief description of DAS and CAIMS. The handbook also describes the data acquisition procedures and estimates of uncertaintiy in the measured data. 


\section{GENERAL ENVIRONMENTS}

A site plan for the NBS Passive Solar Test Building is given in figure 1. Note that the contour slopes downward from south to north at the building site. Grass surrounds the building except for the concrete walkway and blacktop drive. Immediately to the south, a coarse gravel bed (reflectance $\simeq 0.2$ ) extends out $1.12 \mathrm{~m}(3.67 \mathrm{ft})$ from the south wall. Beyond that, the ground is rocky earth with sparse grass (reflectance $=0.2$ ). During the winter, this area is sometimes covered with snow (reflectance $=0.7$ ). There is no significant shading effect from trees or other external objects.

The American Institute of Architects Research Corporation (AIA/RC) regional climatic classification for Washington, DC, is type 7A (Atlantic Coast).* The annual number of heating degree days is $2347^{\circ} \mathrm{C}$-days $\left(4224^{\circ} \mathrm{F}\right.$-days), the average winter temperature is $7.6^{\circ} \mathrm{C}\left(45.7^{\circ} \mathrm{F}\right)$, and the 97.5 percent design dry-bulb temperature for heating is $8.3^{\circ} \mathrm{C}\left(17^{\circ} \mathrm{F}\right)$. The annual number of cooling degree days is $522^{\circ} \mathrm{C}$-days $\left(940^{\circ} \mathrm{F}\right.$-days), and the 2.5 percent design dry-bulb and mean coincident wet-bulb temperatures are $32.8^{\circ} \mathrm{C}\left(91^{\circ} \mathrm{F}\right)$ and $23.3^{\circ} \mathrm{C}\left(74^{\circ} \mathrm{F}\right)$, respectively. Annual average wind speeds are medium $[11$ to $24 \mathrm{~km} / \mathrm{h}$ (7 to $15 \mathrm{mph}$ )] and prevailing winds are from the southwest. Cloud cover is 0.65 to 0.75 from December to March and 0.55 to 0.65 for the rest of the year. The nearest Typical Meterological Year weather station is at the Dulles International Airport in Sterling, VA.

Monthly rain and snowfall figures for National Airport, Washington, DC, are as follows (suitable figures were not available for Dulles International Airport):

\begin{tabular}{|c|c|c|c|c|}
\hline & & & & \\
\hline & $\mathrm{cm}$ & in. & $\mathrm{cm}$ & in. \\
\hline January & 6.7 & 2.6 & 11.4 & 4.5 \\
\hline February & 6.2 & 2.5 & 12.7 & 5.0 \\
\hline March & 8.5 & 3.3 & 6.1 & 2.4 \\
\hline April & 7.3 & 2.7 & trace & - \\
\hline May & 9.8 & 3.7 & trace & - \\
\hline June & 8.8 & 3.5 & 0 & 0 \\
\hline July & 10.5 & 4.1 & 0 & 0 \\
\hline August & 11.9 & 4.7 & 0 & 0 \\
\hline September & 7.8 & 3.1 & 0 & 0 \\
\hline October & 6.8 & 2.7 & trace & - \\
\hline November & 7.4 & 2.9 & 1.8 & 0.7 \\
\hline December & 7.6 & 3.0 & 9.7 & 3.8 \\
\hline Annual & $\overline{99.3}$ & $\overline{38.8}$ & 41.7 & 16.4 \\
\hline
\end{tabular}

"Regional Guidelines for Building Passive Energy Conserving Homes," prepared by the AIA/RC for the U.S. Department of Housing and Urban Development, HUDPDR-355 November 1978, p. 125. 


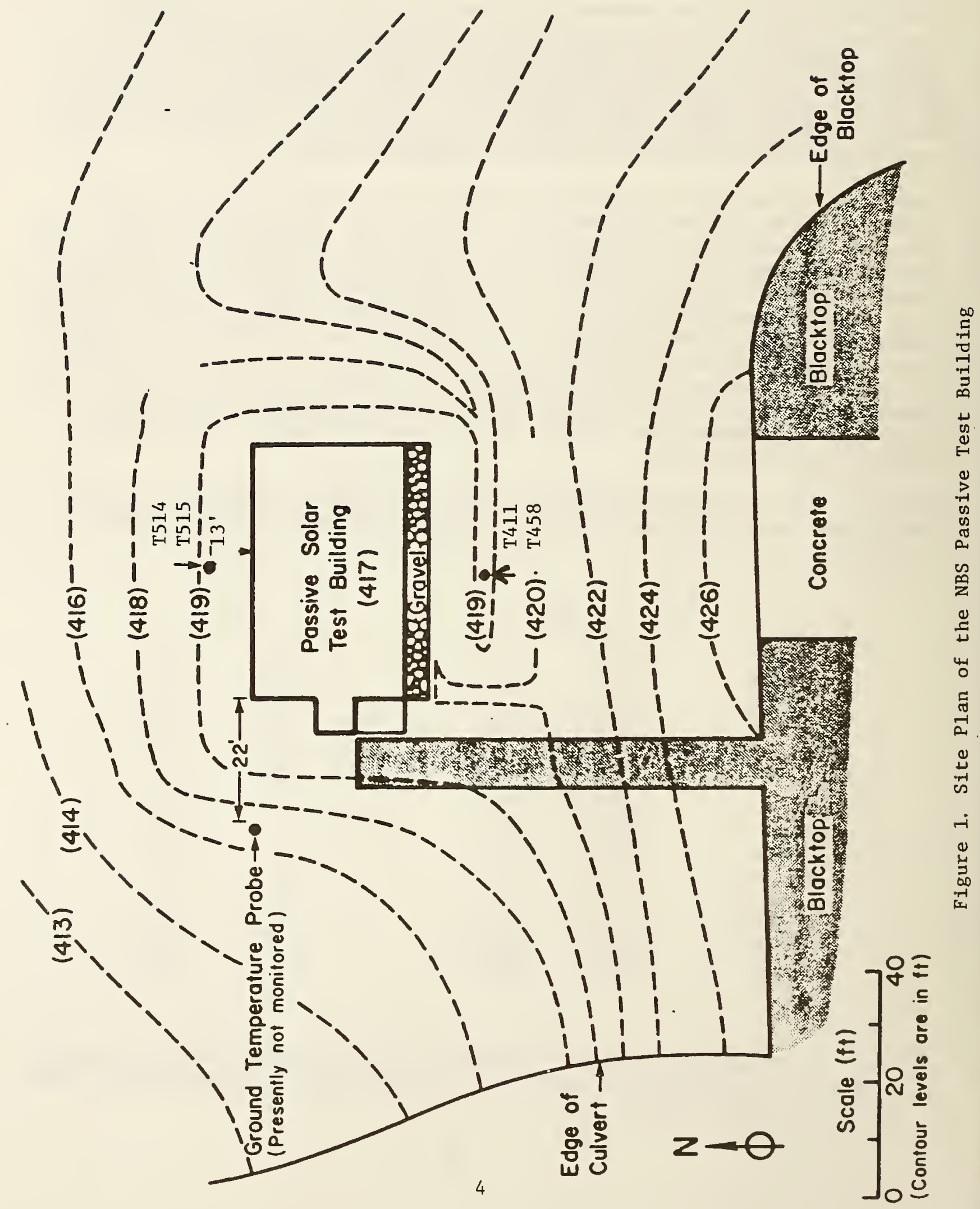




\section{DESCRIPTION OF THE BUILDING}

\subsection{GENERAL}

The NBS Passive Solar Test Facility is located in Gaithersburg, MD, (latitude $39^{\circ} \mathrm{N}$, longitude $77.3^{\circ} \mathrm{W}$ ) on an open field with no shading from the surroundings. The building is a rectangular one-story, slab on grade, frame structure, with the long axis running from east to west. The building is especially designed to be reconfigurable so that passive solar features can be installed with minimum cost and effort. For example, the interior walls are not load bearing and thus can be removed or redesigned. Also, the structure of the south ceiling could support a $0.3 \mathrm{~m}$ (12 in) roof pond.

A photograph showing the south elevation of the building is presented in figure 2 , and the floor plane of the current configuration is shown in figure 3 . The current configuration provide four cells of equal floor area and an "entry" adjoining cell 非 $l$ on the west of the building. Each cell has a floor area of $30.1 \mathrm{~m}^{2}\left(324 \mathrm{ft}^{2}\right)$ and a total volume of $88.4 \mathrm{~m}^{3}\left(3122 \mathrm{ft}^{3}\right)$. A description of the cells will be given later in this section.

The bullding envelope or the envelope of each cell may be divided into four types of surfaces/components: ceiling/roof, floor, walls, and windows. A description of construction details and material properties for each surface type are given below. 


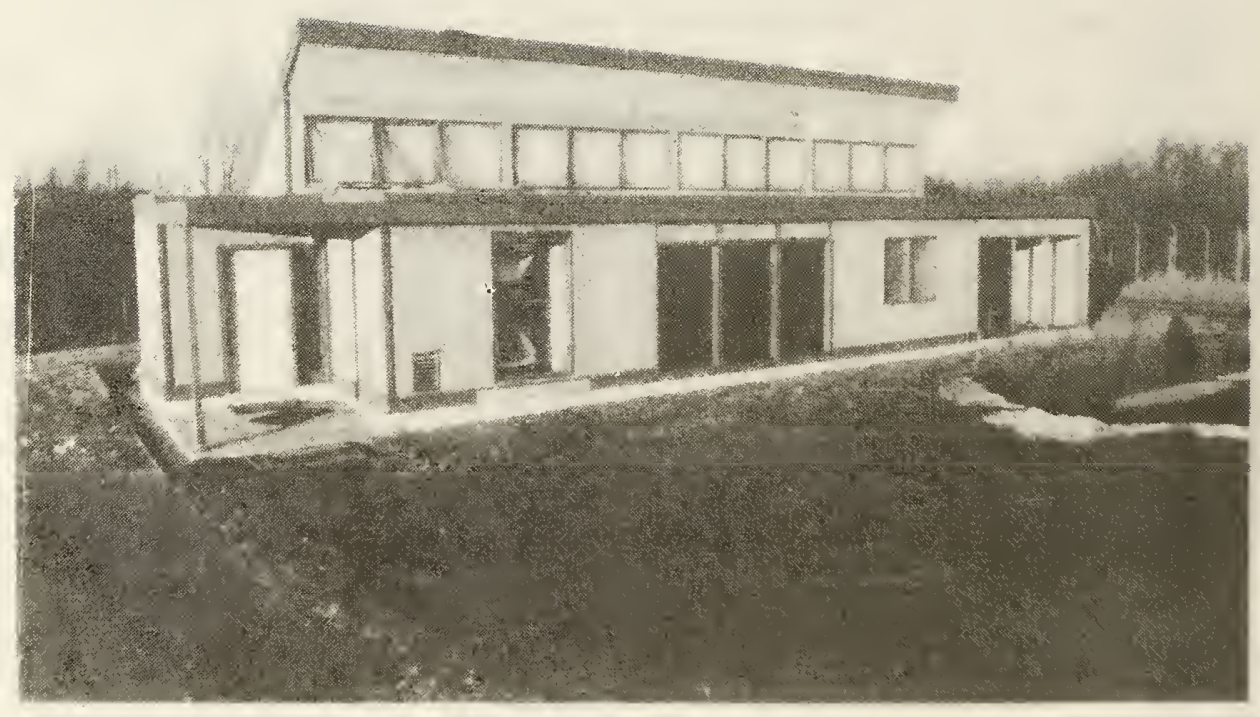

Figure 2. Photograph of NBS Passive Solar Test Building 


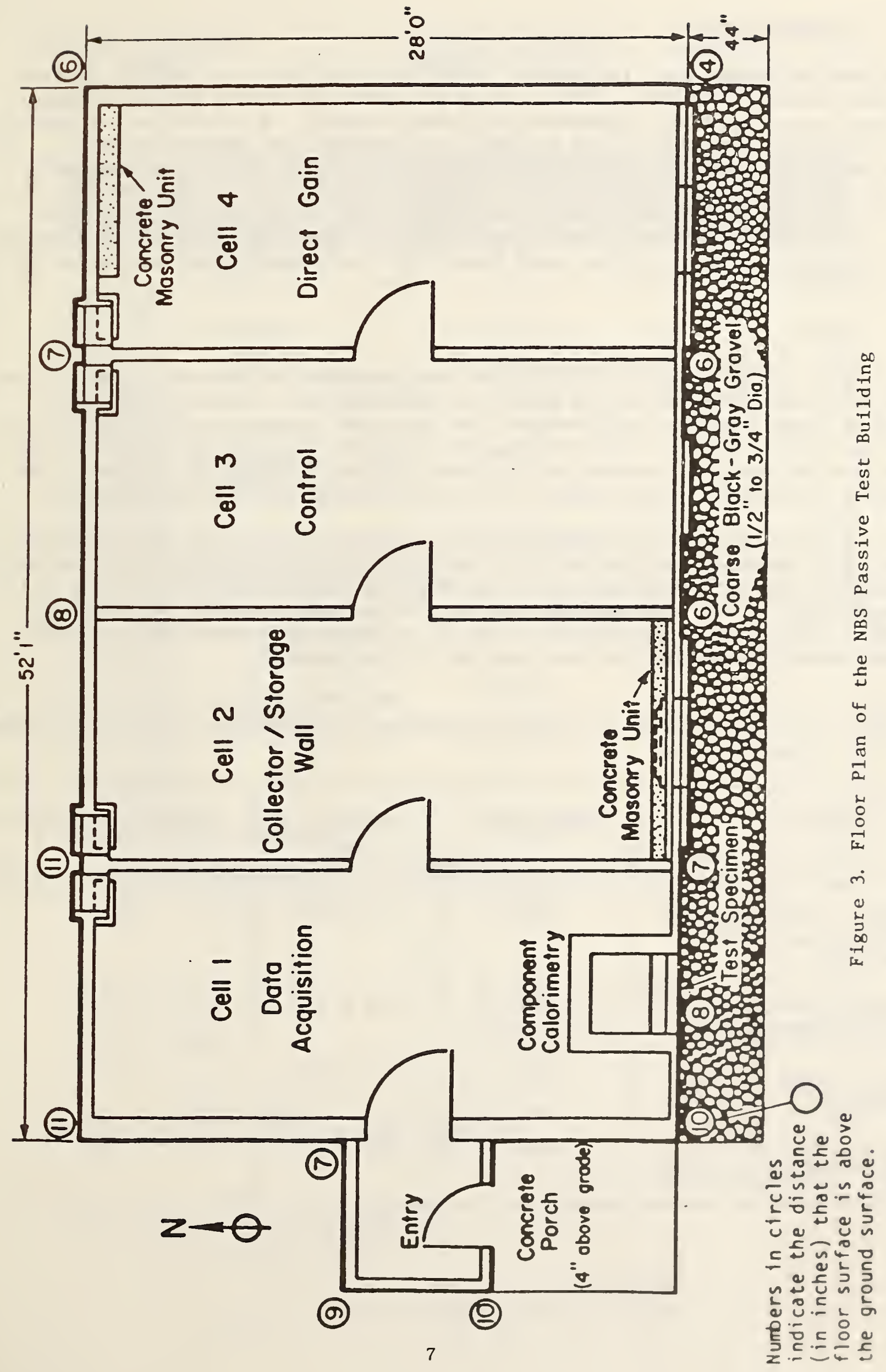




\subsection{CEILING/ROOF}

The roof is divided into two parts: a $4.77 \mathrm{~m}$ (15.67 ft) south section of flat builtup construction and a $4.58 \mathrm{~m}$ ( $11.25 \mathrm{ft}$ ) north section of asphalt shingle covered sloped roof to accommodate clerestory windows. Both sections of the roof are insulated with $240 \mathrm{~mm}(9.5 \mathrm{in})$ of fiberglass bat insulation. The ceiling height under the flat roof is $2.45 \mathrm{~m}(8.08 \mathrm{ft})$. The ceiling height under the sloped roof section varies from $4.64 \mathrm{~m}(15.25 \mathrm{ft})$ at the south end to $2.45(8.08 \mathrm{ft})$ at the north end. A section view of both the flat and sloped roof are shown in figures 4 and 5, respectively. The properties of the construction materials as well as the total $\mathrm{R}$-value of the component are also given in the figures.

\subsection{FLOOR}

The floor, a slab on grade construction, was designed to be of $102 \mathrm{~mm}$ ( $4 \mathrm{in}$ ) of concrete over $102 \mathrm{~mm}$ ( $4 \mathrm{in}$ ) of gravel on compacted soil. However, the core samples taken from the slab revealed that the slab thickness varies from 120 to $150 \mathrm{~mm}$ ( 4.8 to $6.0 \mathrm{in}$ ). The core samples also indicate that the gravel beneath the slab has settled, leaving an air gap of 0.0 to $30 \mathrm{~mm}(0.0$ to $1.2 \mathrm{in})$. The details of core drilling locations and slab thickness are shown in figure 6.

Most of the floor slab is constructed with concrete which is not air entrained, while the removable sections of the floor in the direct gain cell (cell 非) are built with air entrained concrete. The measured values of density and thermal conductivity of the slab material and the storage wall material are given in table 1. Floor is insulated with $50 \mathrm{~mm}$ ( $2 \mathrm{in}$ ) extruded polystyrene insulation board along the perimeter slab to the top of the footings.

Table 1. Measured Values of Density and Thermal Conductivity of Slab and Storage Wall Material

\begin{tabular}{|l|c|c|c|}
\hline \multicolumn{1}{|c|}{ Material } & $\begin{array}{c}\text { Temperature } \\
{ }^{\circ} \mathrm{C}\end{array}$ & $\begin{array}{c}\text { Density } \\
\mathrm{kg} / \mathrm{m}^{3}\end{array}$ & $\begin{array}{c}\text { Thermal Conductivity, } \mathrm{k} \\
\mathrm{W} / \mathrm{m}^{\circ} \mathrm{C}\end{array}$ \\
\hline $\begin{array}{l}\text { Concrete, (air-entrained } \\
\text { removable floor section } \\
\text { in cell 非) }\end{array}$ & 22.4 & $2.2 \times 10^{3}$ & 1.37 \\
$\begin{array}{l}\text { Concrete, not air- } \\
\text { entrained floor slab } \\
\text { Concrete block }\end{array}$ & 22.6 & $2.3 \times 10^{3}$ & 1.45 \\
$\begin{array}{l}\text { storage wall } \\
\frac{\text { Mortar, within the }}{\text { cores of concrete blocks }}\end{array}$ & 21.8 & $1.5 \times 10^{3}$ & 0.56 \\
\hline
\end{tabular}


$R=.17$

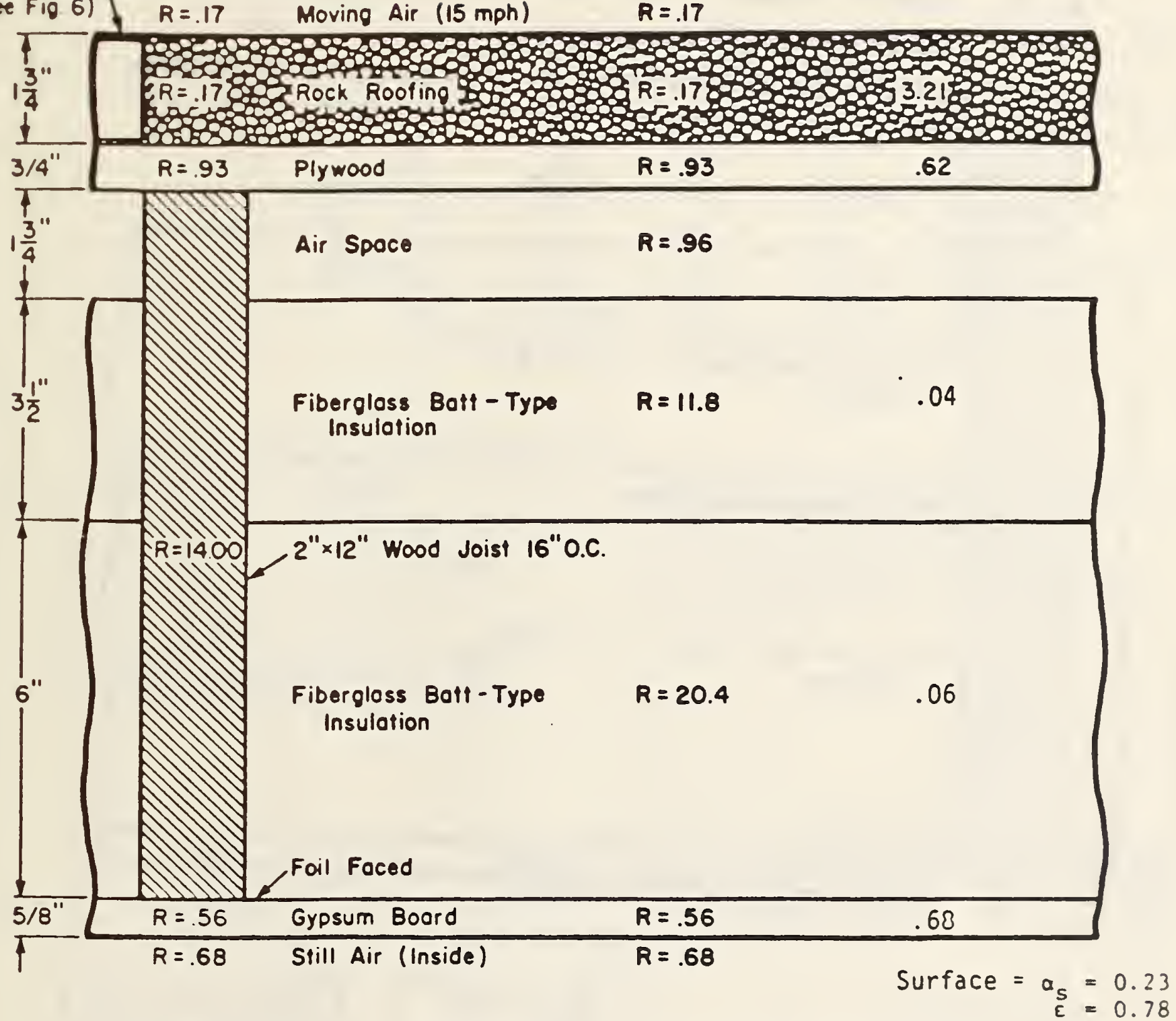

$R_{s}=16.51$
Areo $=9.5 \%$

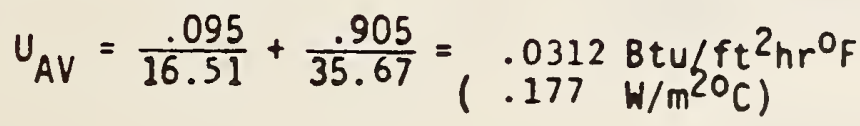

$R_{A V}=\frac{1}{U_{A V}}=\begin{aligned} & 32.05 \mathrm{ft}^{2} \mathrm{hr}^{\circ} \mathrm{F} / \mathrm{Btu} \\ & \left(5.644 \mathrm{~m}^{2} \mathrm{C} / \mathrm{W}\right)\end{aligned}$

Figure 4. Cross Section of the Flat Roof 
Thermal Resistance (at froming)
Thermal Resistance (botween froming)
Heot

Copocity

Surface $=a_{s}=.90$

$1 / 8^{\circ} \quad P=.17 \quad$ Moving Air (15 mph)

$R=.17$

.22

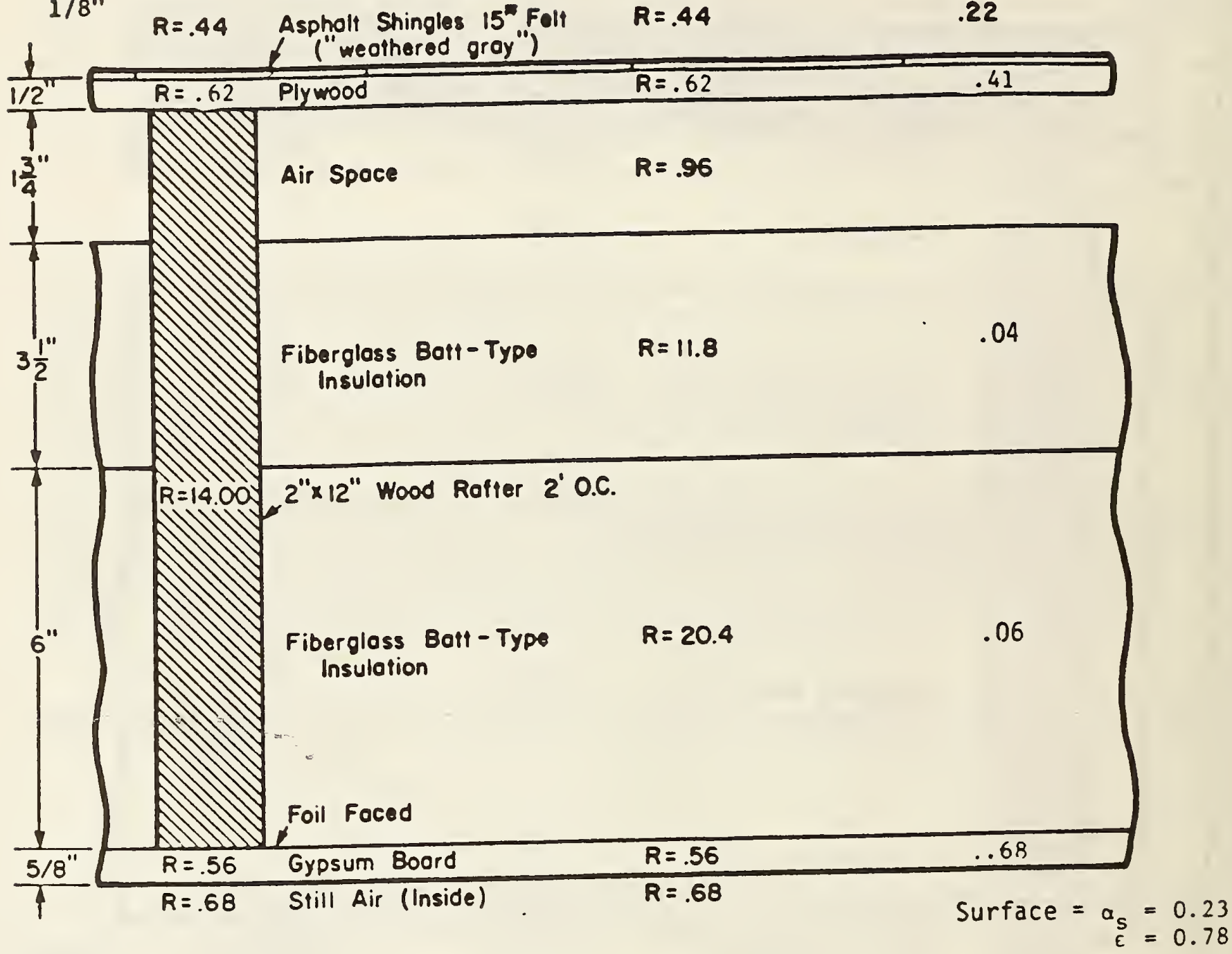

$R_{s}=16.47$

Areo $=6.5 \%$

$R_{i}=35.63$

Areo $=93.5 \%$

$\frac{m_{\mathrm{CP}}}{A}=1.41 \mathrm{Bru} / \mathrm{ft}^{2 \circ} \mathrm{F}$ (-8.5 $\mathrm{kJ} / \mathrm{m}^{2}{ }^{\circ} \mathrm{C}$ )

$U_{A V}=\frac{.065}{16.47}+\frac{.935}{35.64}=\begin{array}{ll}.0301 \quad \mathrm{Btu} / \mathrm{ft}^{2} \mathrm{hr} \mathrm{H}^{0} \mathrm{~F} \\ \left(.1716 \mathrm{~W} / \mathrm{m}^{20} \mathrm{C}\right)\end{array}$

$R_{A V}=\frac{1}{U_{A V}}=\begin{aligned} & 33.22 \mathrm{ft}^{2} \mathrm{hr} \mathrm{r}^{\circ} \mathrm{F} / \mathrm{Btu} \\ & \left(5.350 \mathrm{~m}^{20} \mathrm{C} / \mathrm{W}\right)\end{aligned}$

Figure 5. Cross Section of the Sloped Roof 

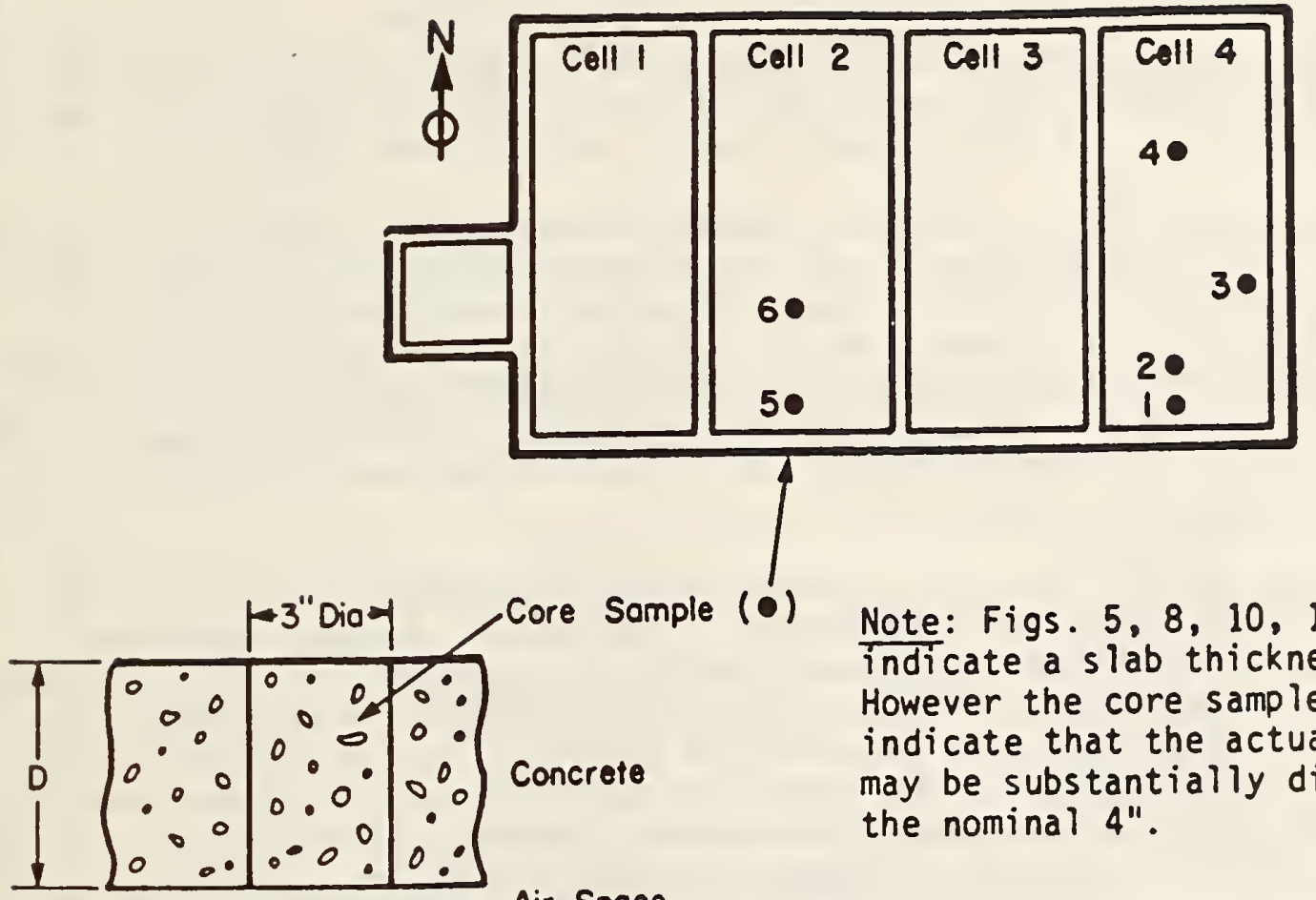

Note: Figs. $5,8,10,12$, and 14 indicate a slab thickness of $4 "$. However the core samples taken indicate that the actual thickness may be substantially different than the nominal 4".

Air Spoce

I Bobs

\begin{tabular}{|c|c|c|c|c|}
\hline $\begin{array}{l}\text { Core } \\
\text { No. }\end{array}$ & $\begin{array}{l}\text { Distance from South } \\
\text { Wall of Cell }\end{array}$ & $\begin{array}{c}\text { Distance from East } \\
\text { Wall of Cell }\end{array}$ & $\begin{array}{c}\text { Core Thickness } \\
D \\
(\text { in) }\end{array}$ & $\begin{array}{c}\text { Air Space } \\
t \\
\text { (in) }\end{array}$ \\
\hline 1 & $I^{\prime}$ ¿" & $6^{\prime} 0^{\prime \prime}$ & 5.6 & 0.1 \\
\hline 2 & $2^{\prime} 7^{\prime \prime}$ & 6' & 6.0 & 0.0 \\
\hline 3 & $10^{\prime} 8^{\prime \prime}$ & 1'0" & 4.9 & 0.8 \\
\hline 4 & $17^{\prime} 11^{\prime \prime}$ & $6^{\prime} 0^{\prime \prime}$ & 5.1 & 0.1 \\
\hline 5 & $1^{\prime} 3^{\prime \prime}$ & $6^{\prime} 0^{\prime \prime}$ & 5.7 & 0.1 \\
\hline 6 & $9^{\prime \prime} 9^{\prime \prime}$ & $6^{\prime} \quad 2^{\prime \prime}$ & 4.8 & 1.2 \\
\hline
\end{tabular}

Figure 6. Core Drilling Locations and S1ab Thicknesses 


\subsection{WALLS}

The walls may be divided into the following five types: (1) east and west outer walls; (2) inner partition walls; (3) north wall; (4) south wall; and (5) thermal storage wall. A description of each type in given below.

East and West Outer Walls. The east and west outside walls are doubles-stud (two rows of $2 \times 4^{\prime}$ s separated by air space) from construction covered with insulating sheathing and cedar siding. These walls are insulated with two layers of $90 \mathrm{~mm}(3.5 \mathrm{in})$ fiberglass batt insulation. The double studding and extra insulation are used to reduce the heat transfer through the end walls. A section view showing the construction of these walls is shown in figure 7 . The properties of the construction materials as well as the total $\mathrm{R}$-value of the wall are also given in figure 7.

Inner Partition Walls. The inner partition walls, separating the adjacent cells, are single-stud frame construction. Both sides of these wall have $38 \mathrm{~mm}(1.5 \mathrm{in})$ of extruded polystyrene behind the gypsum board, and are insulated with $90 \mathrm{~mm}$ ( $3.5 \mathrm{in}$ ) fiberglass batt insulation. A section view showing the construction of these walls is presented in figure 8 . The properties of the materials of construction and the total $\mathrm{R}$-value of the wall are also shown in figure 8. Heavily insulated metal doors with a thermal resistance of $0.44 \mathrm{~m}^{2 \circ} \mathrm{C} / \mathrm{W}(\mathrm{R}=2.5)$ serve as a passageway between the cells.

North Wall. The north outside wall is single-stud frame construction covered with insulating sheathing and cedar siding. The wall is insulated with $90 \mathrm{~mm}$ ( 3.5 in) fiberglass batt insulation. The section view, showing the construction details, material properties, and total $R$-value of the wall is given in figure 9. The north wall contains a wood casement window for each cell. A plane and section view of the north wall, shown in figure 10, indicates the location of the window and the fan coil unit.

South wall. The south wall is divided into two levels: upper south wall and lower south wall. The upper south wall contains a clerestory window for each cell. The opaque portions of the upper level south wall is of single-stud from construction covered with $12.7 \mathrm{~mm}(0.5 \mathrm{in})$ plywood and cedar siding and insulated with $90 \mathrm{~mm}$ ( $3.5 \mathrm{in}$ ) fiberglass batt insulation. Figure 11 shows a section view of the opaque portion of the upper south wall along with the material properties and total $\mathrm{R}$-value for the wall.

The lower level south wall in each cell is different to accommodate different passive solar features. The opaque portion of the lower south wall is of the same construction as the north wall described previously. 


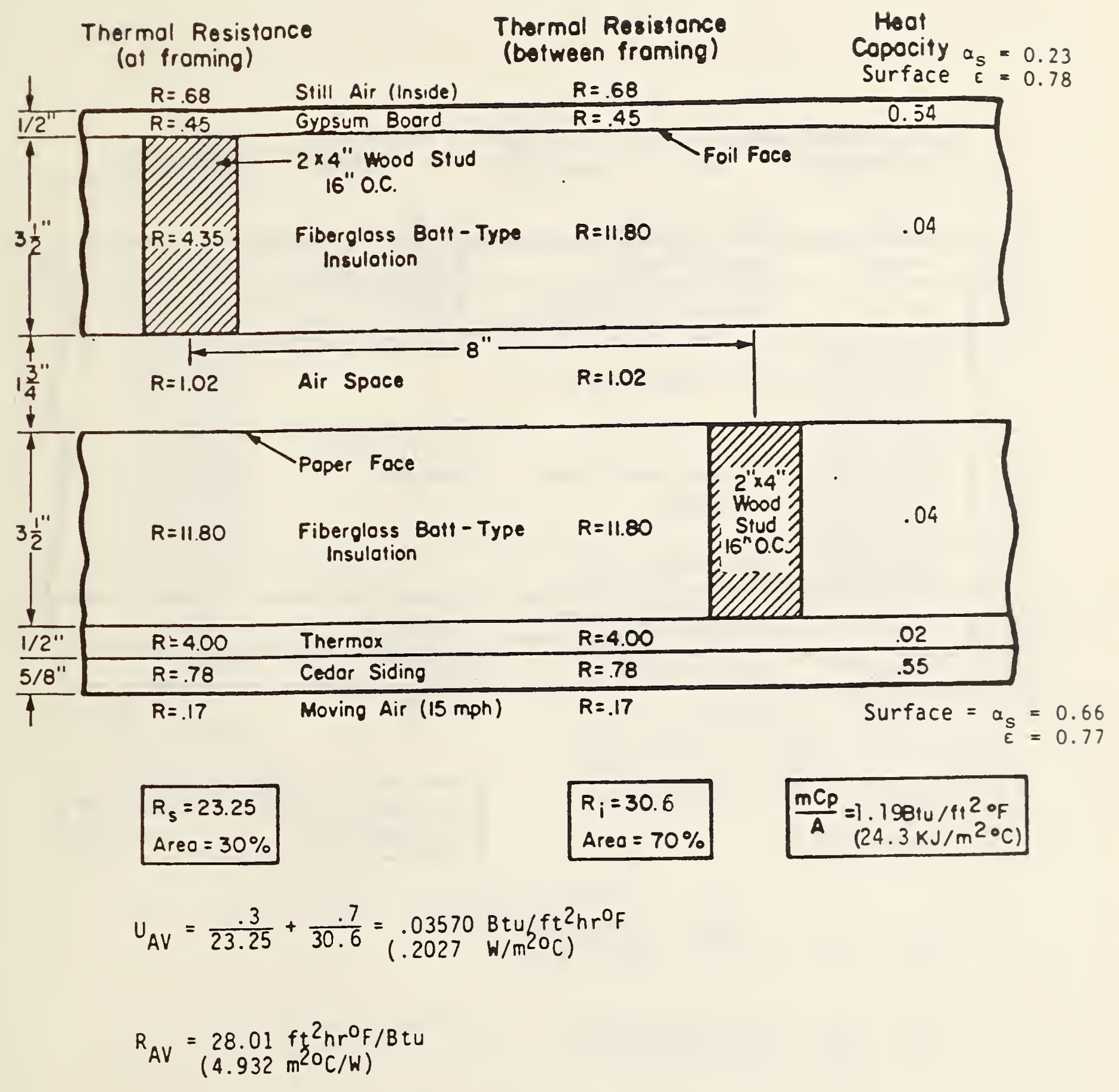

Note: Although the studs are 8" from center to center (accounting for the double wall) in calculating $R$ values they are assumed to occupy $30 \%$ of the wall area in order to compensate for multidirectional heat flow and because of the additional studs used in corners and as top and bottom plates.

Figure 7. Cross Section of the East/West Outside Walls 
Thermal Resistonce (of froming)
Thermal Resistonce (between froming)

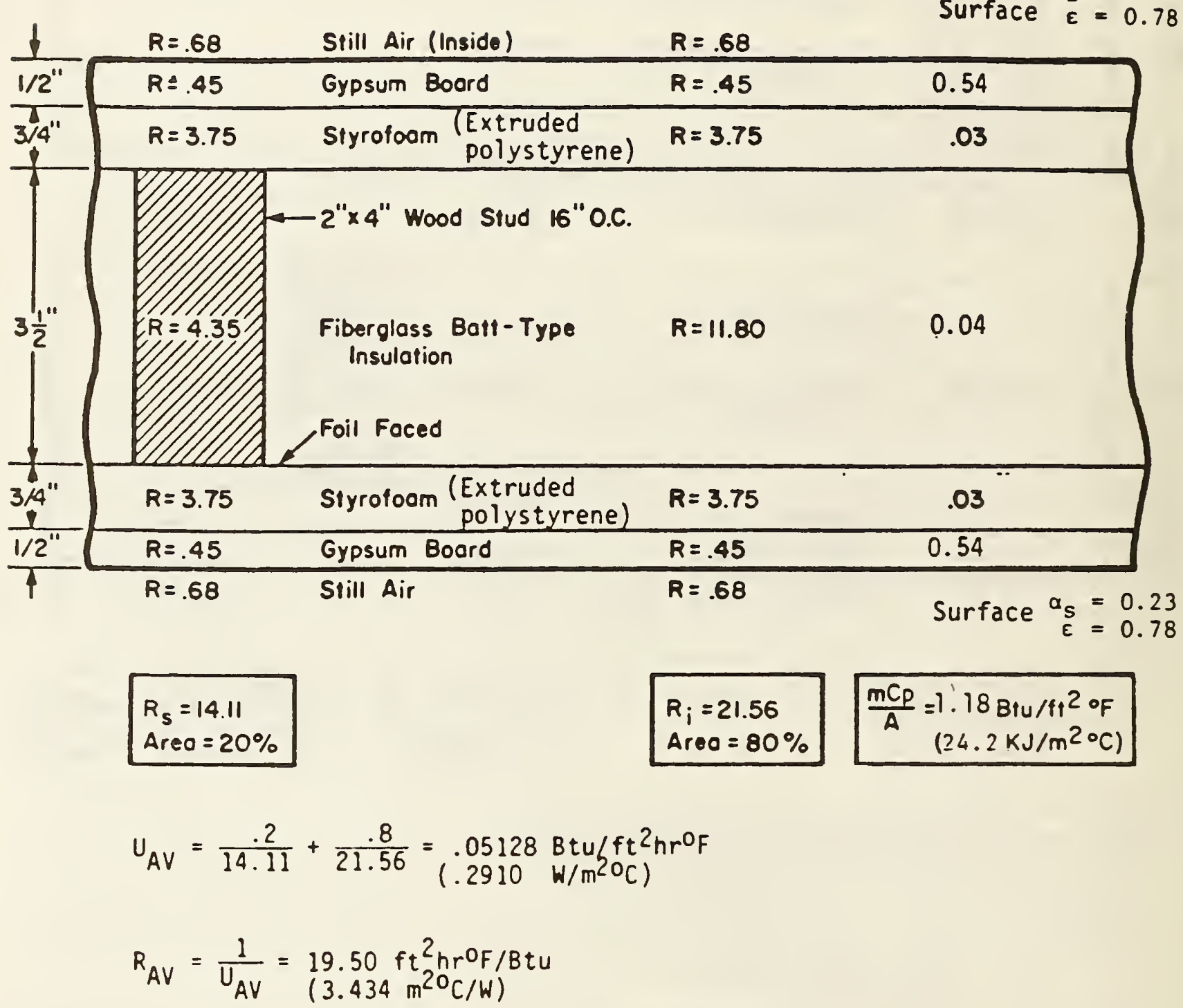

Note: Although the studs are 16 " from center to center, in calculating $R$ values, they are assumed to occupy $20 \%$ of the wall area in order to compensate for multidirectional heat flow and because of the additional studs used around doors, in corners, and as top and bottom plates.

Figure 8. Cross Section of the Inside Partition Wall 
Thermal Resistance (of froming)
Thermal Resistonce (bofween froming)

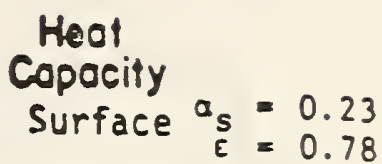

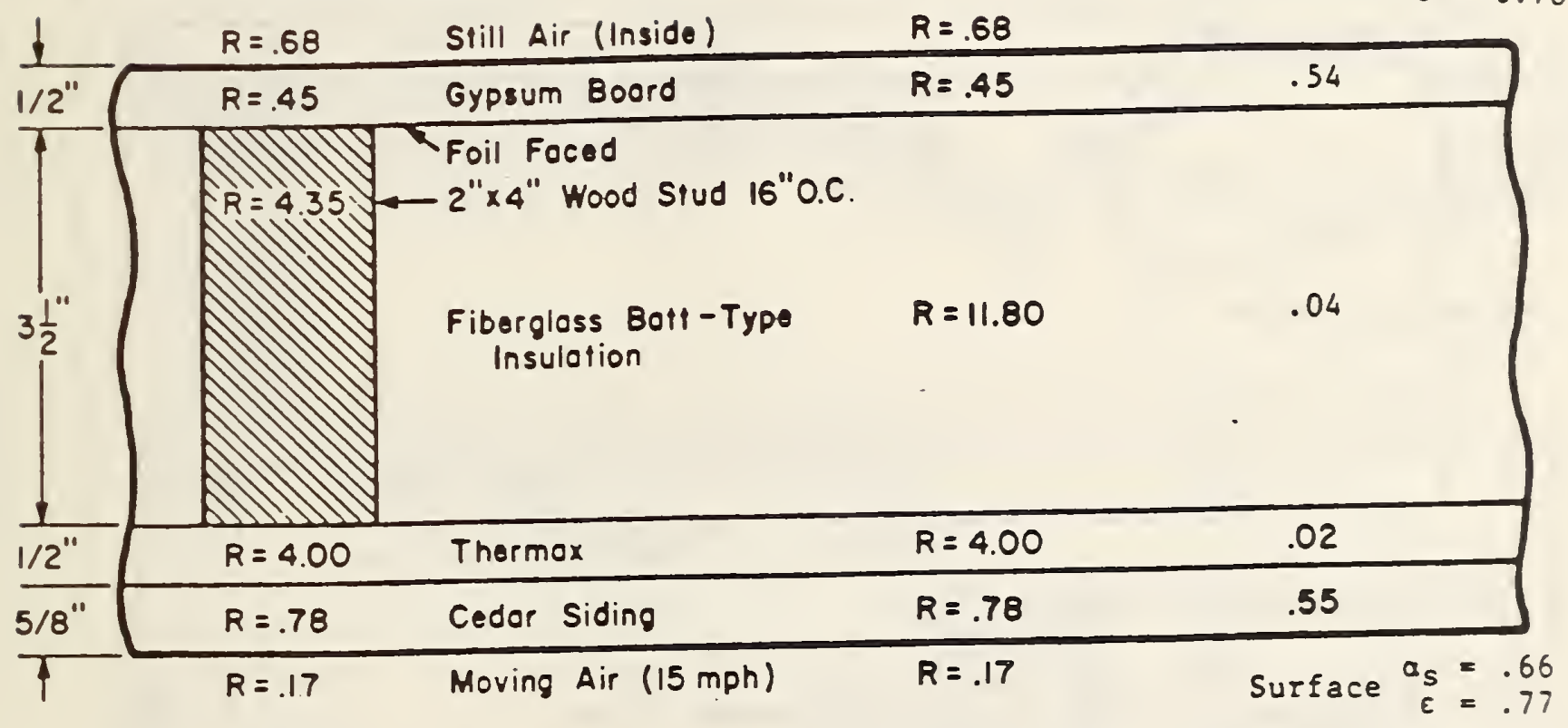

$R_{S}=10.43$

$R_{i}=17.88$

$\frac{m C_{P}}{A}=1.15 \mathrm{Btu} / \mathrm{ft}^{2}{ }^{\circ} \mathrm{F}$

Areo $=80 \%$ R $\left.3.5 \mathrm{~kJ} / \mathrm{m}^{\circ}{ }^{\circ} \mathrm{C}\right)$

$U_{A V}=\frac{.2}{10.43}+\frac{.8}{17.88}=\begin{array}{ll}.06392 . \mathrm{Btu} / \mathrm{ft}^{2} \mathrm{hr} \mathrm{r}^{0} \mathrm{~F} \\ \left(.3629 \mathrm{~W} / \mathrm{m}^{20} \mathrm{C}\right)\end{array}$

$R_{A V}=\frac{1}{U_{A V}}=\frac{15.65 \mathrm{ft}^{2} \mathrm{hr}^{0} \mathrm{~F} / \mathrm{BtU}}{\left(2.755 \mathrm{~m}^{2} \mathrm{OC} / \mathrm{H}\right)}$

Figure 9. Cross Section of the North Wall 
Section $A A$
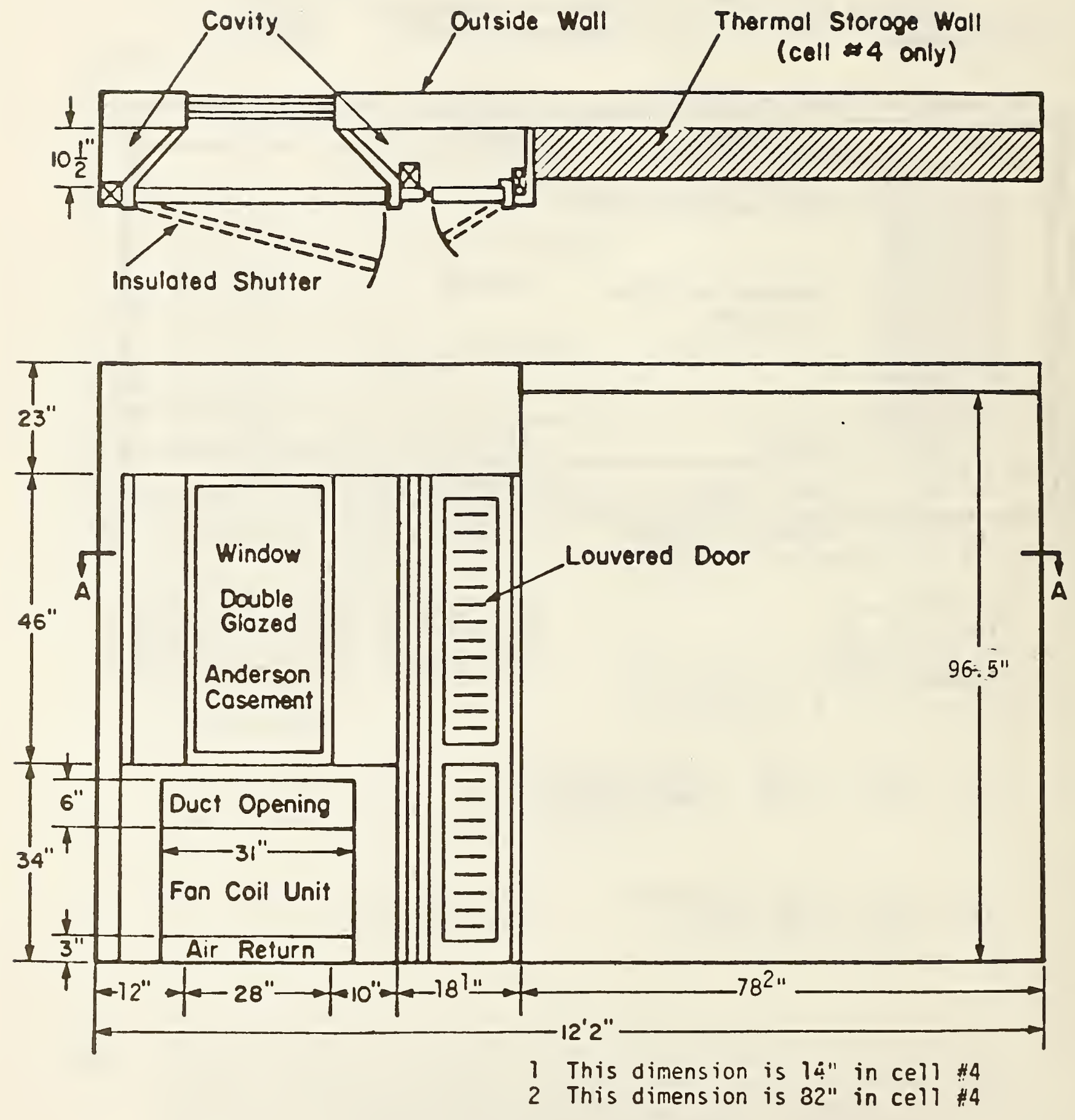

Figure 10. Plan and Section View of the North Wall (Cell $\# 1$ and $\# 3$ are reversed) 


\subsection{WINDOWS}

Each cell has a double-pane, wood casement window with an unobstructed glass area of $0.67 \mathrm{~m}^{2}\left(7.2 \mathrm{ft}^{2}\right)$ located on the north wall of each cell, and a clerestory window located on the upper level south wall. The clerestory window consists of a three-section, double-pane, wood awning window which spans the entire width of the cell with an unobstructed glass area of $3.65 \mathrm{~m}^{2}$ (39.25 $\mathrm{ft}^{2}$ ). Both the clerestory window and the north window are provided with manually operable interior insulating shutters with a thermal resistance value of $1.23 \mathrm{~m}^{2} \mathrm{C} / \mathrm{W}(R=7)$. The windows in the lower south wall for each cell will be described later in section 3.8. The construction details of the headers above the windows and door are shown in figure 12 along with the properties of the materials.

A total of nine different types of windows are installed in the building. Description, location, and properties of the glass of these windows are summarized in figure 13.

\subsection{INDIVIDUAL CELLS}

As indicated earlier, the current configuration of the test building provided four cells of equal floor area. The surfaces and features common to all the cells have been described in section 3.1 to 3.5 . The details of the special features of each cell are described below.

\section{Cel1 1 非 and "Entry"}

A floor plan of cell 非 1 and "Entry" is shown in figure 14 while a longitudinal view is shown in figure 15. Access is gained to the "Entry" by a $0.91 \mathrm{~m}$ ( $3 \mathrm{ft}$ ) wide by $44.0 \mathrm{~mm}(1.75 \mathrm{in})$ thick solid pine door. Cell 非 1 is separated from the "Entry" and cell 非 2 by $44.0 \mathrm{~mm}$ (1.75 in) thick heavy metal doors (metal frame, urethane core).

The cell houses the data acquisition system, (DAS), continuous air infiltration monitoring system, power supply, and the component testing calorimeter and its DAS. A detailed description of the component testing calorimeter may be found in reference 6. 


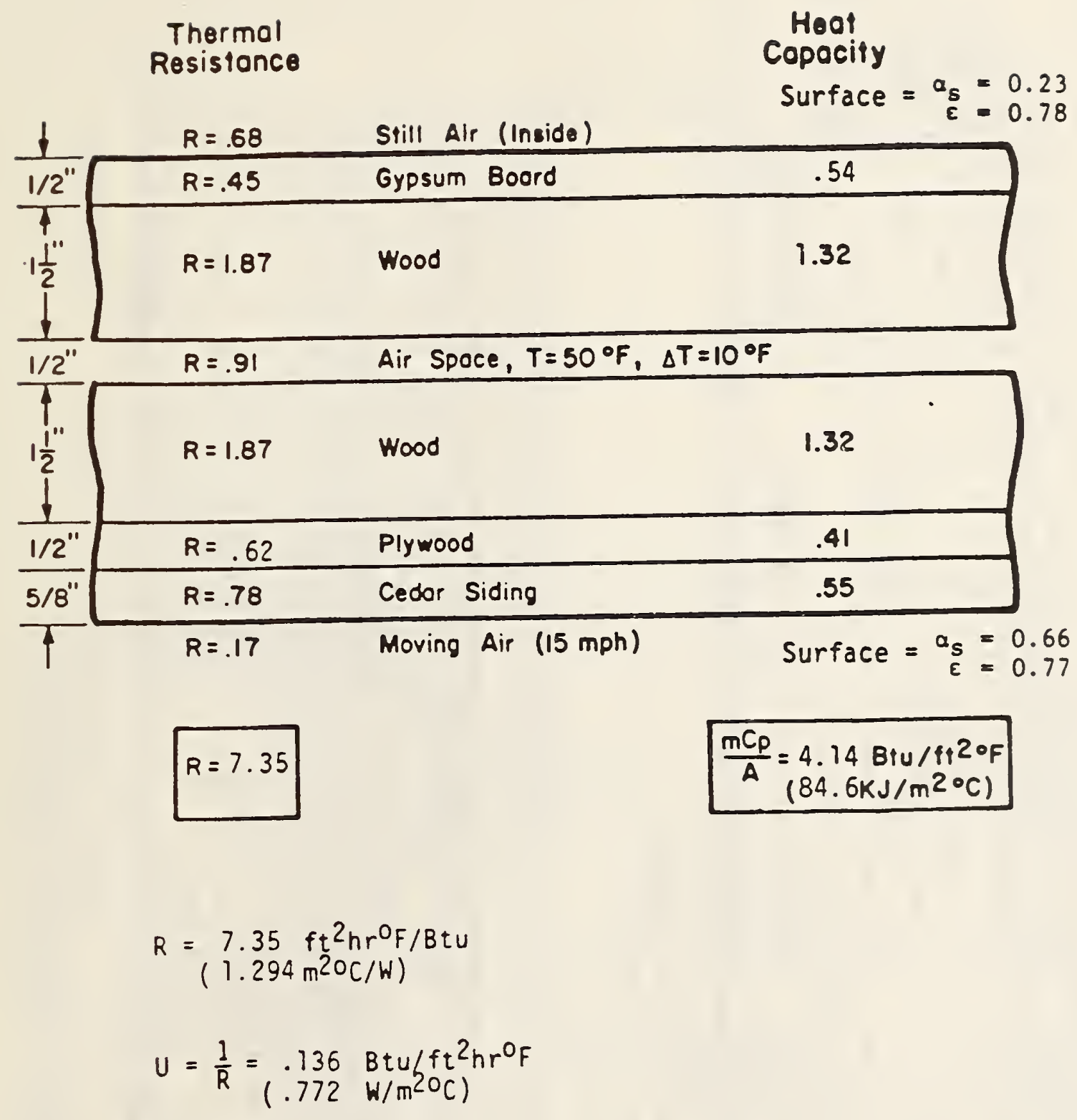

Figure 12. Cross Section of the Window and Door Header 


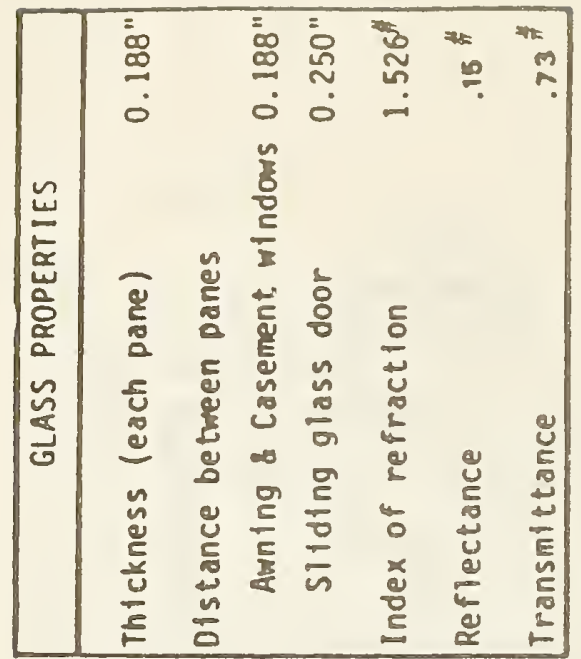

\begin{tabular}{|c|c|c|c|c|c|c|c|c|}
\hline 岁 & & $\frac{\bar{\infty}}{\Sigma}$ & & & ্ָয & $\frac{0}{\sim}$ & & $\frac{5}{\tilde{x}}$ \\
\hline 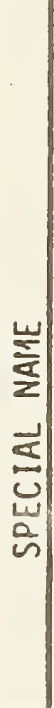 & 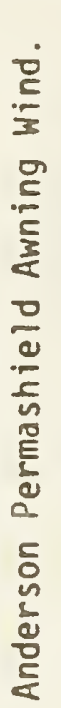 & 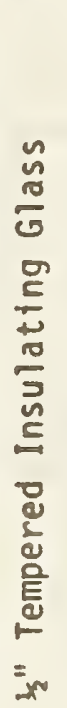 & 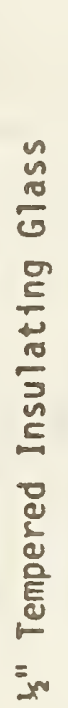 & 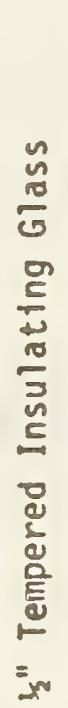 & 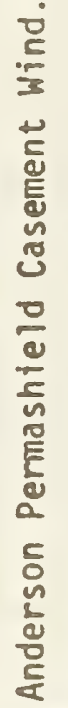 & 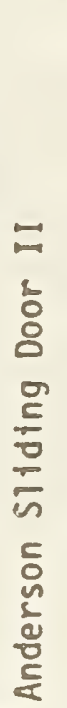 & 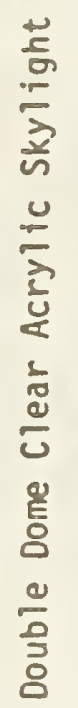 & 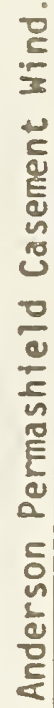 \\
\hline $\begin{array}{l}\vec{U} \\
\vec{n} \\
\frac{\infty}{\Sigma} \\
\Sigma \\
\Sigma\end{array}$ & $\begin{array}{l}0 \\
\infty \\
\forall \\
\bar{x} \\
\bar{\infty} \\
\infty\end{array}$ & $\begin{array}{l}j \\
0 \\
0 \\
\infty \\
x \\
\infty \\
\infty \\
0\end{array}$ & 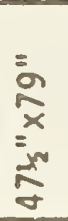 & 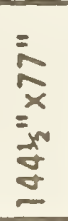 & 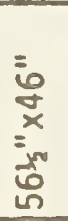 & 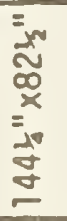 & $\begin{array}{l}j \\
0 \\
0 \\
0 \\
x \\
i n \\
j \\
0\end{array}$ & $\begin{array}{c}\bar{\infty} \\
\infty \\
\dot{x} \\
x \\
\bar{\infty} \\
\underset{\sim}{\infty}\end{array}$ \\
\hline 운 & $\simeq$ & $\sigma$ & $\sigma$ & $m$ & $\sim$ & $m$ & $\sigma$ & $\sigma$ \\
\hline 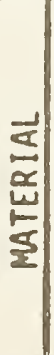 & 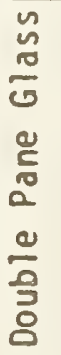 & $\begin{array}{l}\tilde{n} \\
\tilde{0} \\
0 \\
0 \\
\tilde{c} \\
\tilde{0} \\
\frac{0}{0} \\
\frac{0}{0} \\
0 \\
0\end{array}$ & $\begin{array}{l}n \\
\tilde{0} \\
0 \\
0 \\
0 \\
\frac{0}{0} \\
0 \\
0 \\
\frac{0}{0} \\
\frac{0}{8}\end{array}$ & $\begin{array}{l}n \\
0 \\
0 \\
0 \\
0 \\
\frac{0}{0} \\
2 \\
0 \\
\frac{0}{0} \\
0 \\
0\end{array}$ & $\begin{array}{l}\tilde{a} \\
\tilde{\sigma} \\
0 \\
\frac{0}{0} \\
2 \\
\frac{0}{0} \\
\frac{0}{8}\end{array}$ & $\begin{array}{l}\tilde{n} \\
\tilde{0} \\
\tilde{0} \\
0 \\
\tilde{c} \\
0 \\
0 \\
0 \\
\frac{0}{0} \\
0 \\
0\end{array}$ & $\begin{array}{l}\frac{U}{2} \\
\frac{E}{U} \\
\frac{1}{0} \\
\frac{0}{0}\end{array}$ & $\begin{array}{l}\approx \\
\tilde{\sigma} \\
\tilde{\sigma} \\
0 \\
\frac{0}{0} \\
\frac{0}{0} \\
\frac{0}{0}\end{array}$ \\
\hline $\begin{array}{l}\underset{\sim}{N} \\
\sim \\
\sim\end{array}$ & 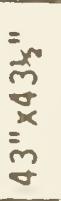 & 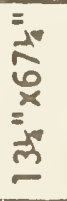 & 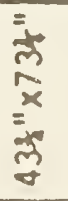 & 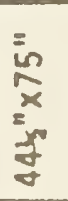 & 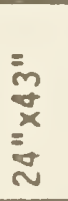 & 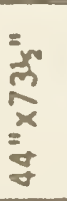 & 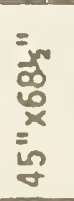 & 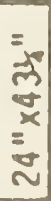 \\
\hline & - & $\sim$ & $m$ & $\theta$ & n & 0 & $n$ & $\infty$ \\
\hline
\end{tabular}

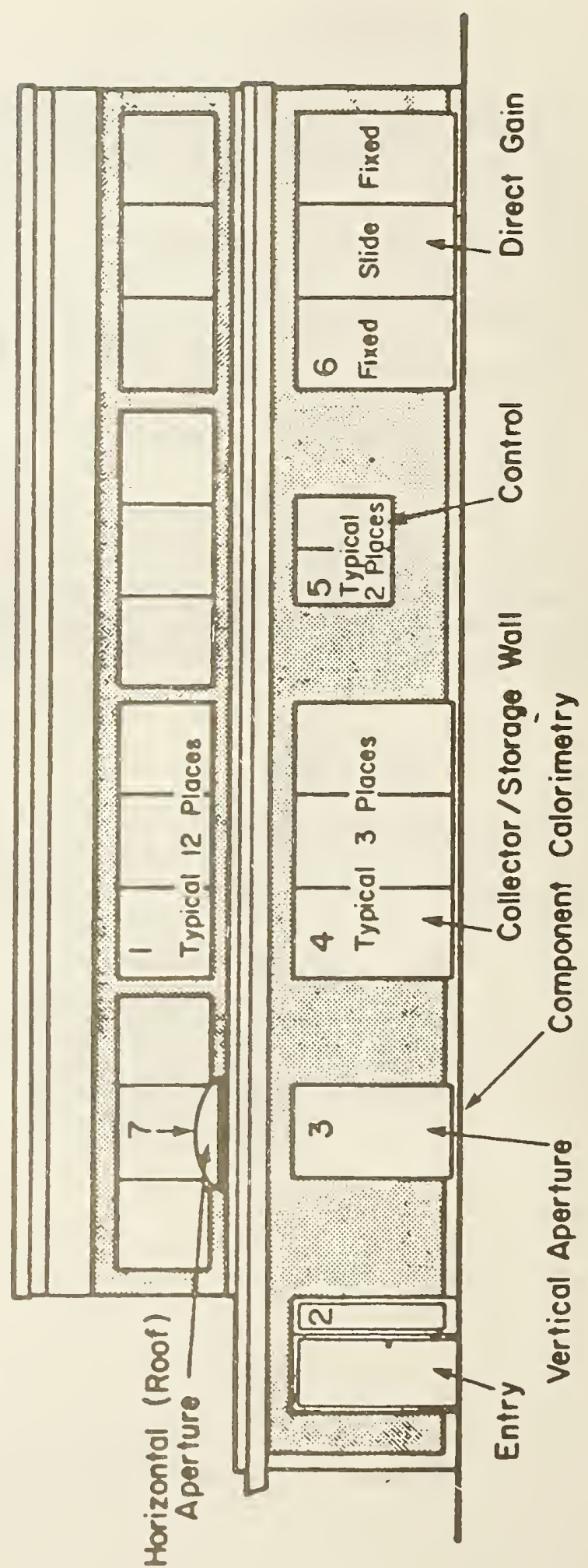

* 돈

ه

4 단

它岳泀

\& ธㄴّ 


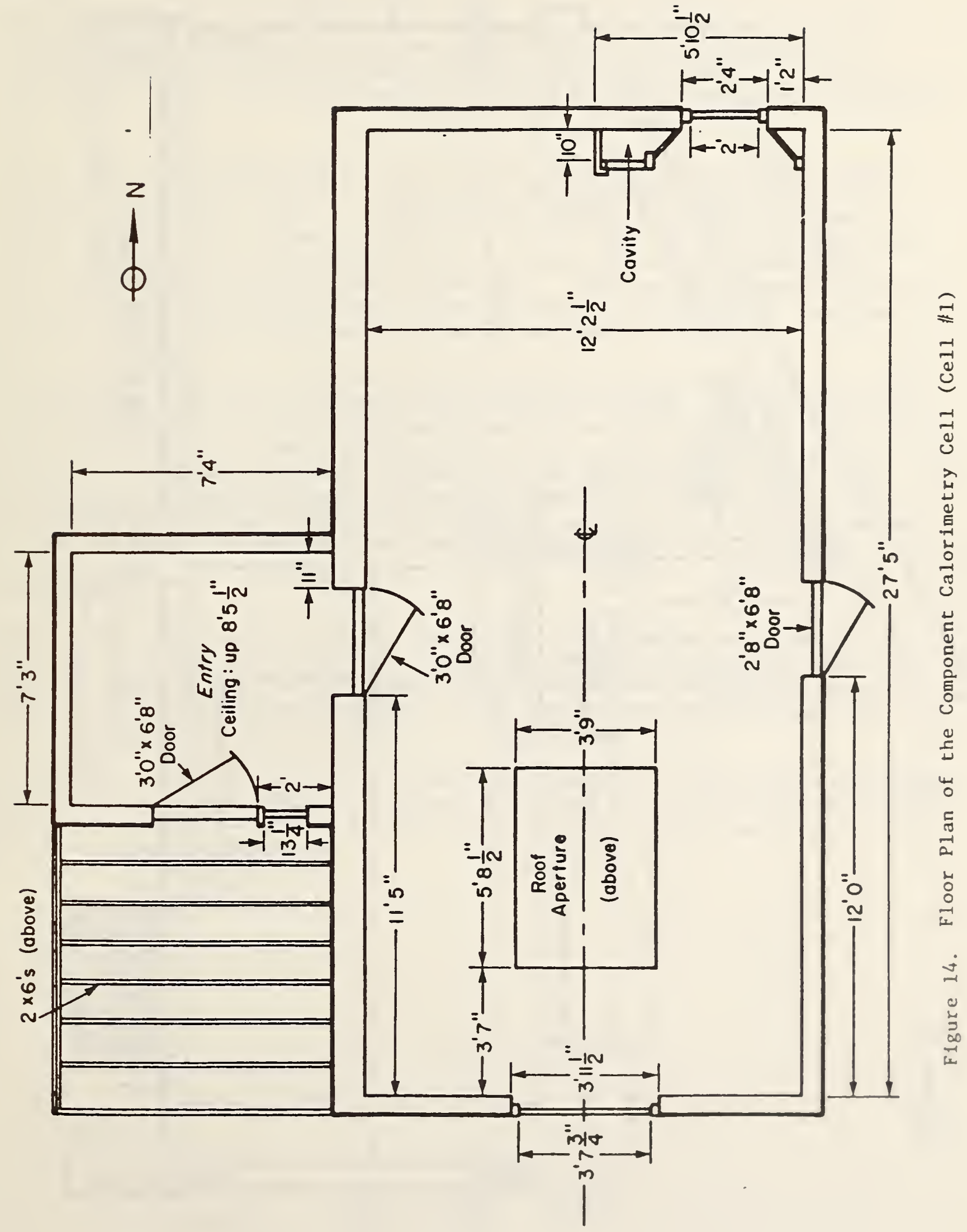




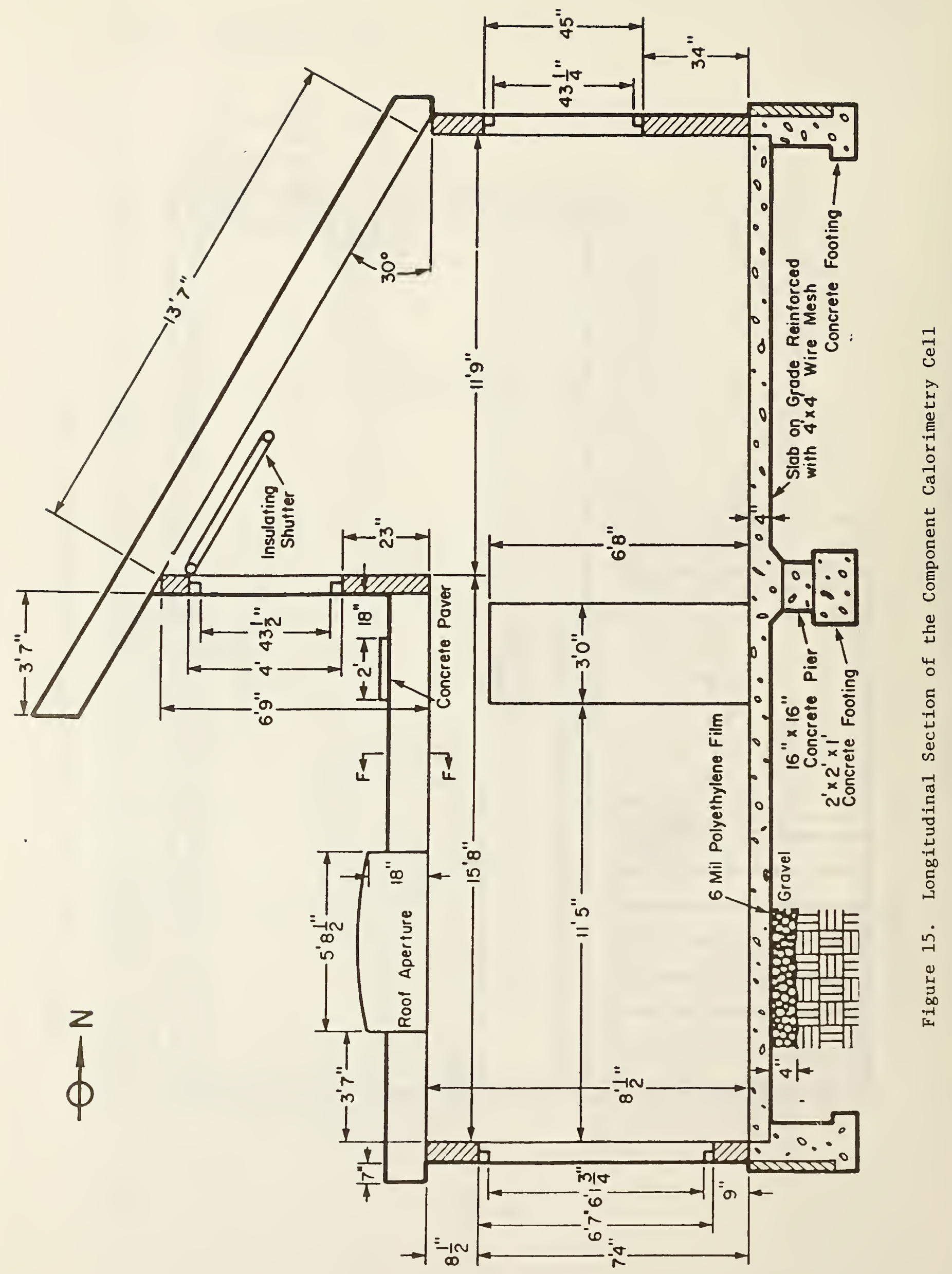


This is a collector storage wall cell which contains a Trombe wall over the entire width of the lower level south wall. A floor plan of the cell is given in figure 16, and a longitudinal view is shown in figure 17 . Cell 非 is separated from the adjacent cells by heavy metal doors (metal frame, urethane core).

The Trombe wall is constructed of $200 \times 400 \times 200 \mathrm{~mm}(8 \times 16 \times 8$ in) concrete masonary units (CMU) with cores filled with mortar. The properties of the material are given in table 1 , along with the properties of concrete used for the floor slab. The Trombe wall is $3.65 \mathrm{~m}(12 \mathrm{ft})$ wide, $2.44(8 \mathrm{ft})$ high, and $200 \mathrm{~mm}(8 \mathrm{in})$ thick. A $140 \mathrm{~mm}(5.5 \mathrm{in})$ air space separates the Trombe wall from a three-section double-glazed window wall. The glazing is made of $3.18 \mathrm{~mm}$ $(.125 \mathrm{in})$ safety insulating glass spaced $15.9 \mathrm{~mm}(0.625 \mathrm{in})$ apart. The window dimensions and glass properties have been summarized in figure 13.

The outside surface of the Trombe wall is painted black while the inside surface is unpainted. Two vent openings, each the size of one $\mathrm{CMU}$, are located $200 \mathrm{~mm}$ ( $8 \mathrm{in}$ ) below the top of the Trombe wall, and $609 \mathrm{~mm}(24 \mathrm{in}$ ) from the right and left side walls. Two identical vent openings are located $200 \mathrm{~mm}$ ( 8 in) below the top of the Trombe wall and vertically in line with the two bottom vents. A schematic of the Trombe wall is shown in figure 18. The Trombe wall can be tested in either vented or unvented conditions, and with the clerestory window shutter in either an open or closed position.

\section{Ce11 非}

This is the control cell. A floor plan of the cell is shown in figure 19, and a longitudinal view is shown in figure 20. Cell 非 3 is separated from the adjacent cells by heavy metal doors. The purpose of the control cell is to allow for the quantitative comparison of the performances of the passive solar features in the two adjacent cells, $1 . e .$, cell $\left.\right|_{2}$ and cell $k_{4}$.

The lower level south wall of the control cell contains a normal sized double-pane casement window. The window is $1.22 \mathrm{~m}$ (48 in) wide by $1.09 \mathrm{~m}$ (43 in) high with an unobstructed glass area of $1.34 \mathrm{~m}^{2}\left(14.4 \mathrm{ft}^{2}\right)$. The properties of the glass are given in figure 13. 


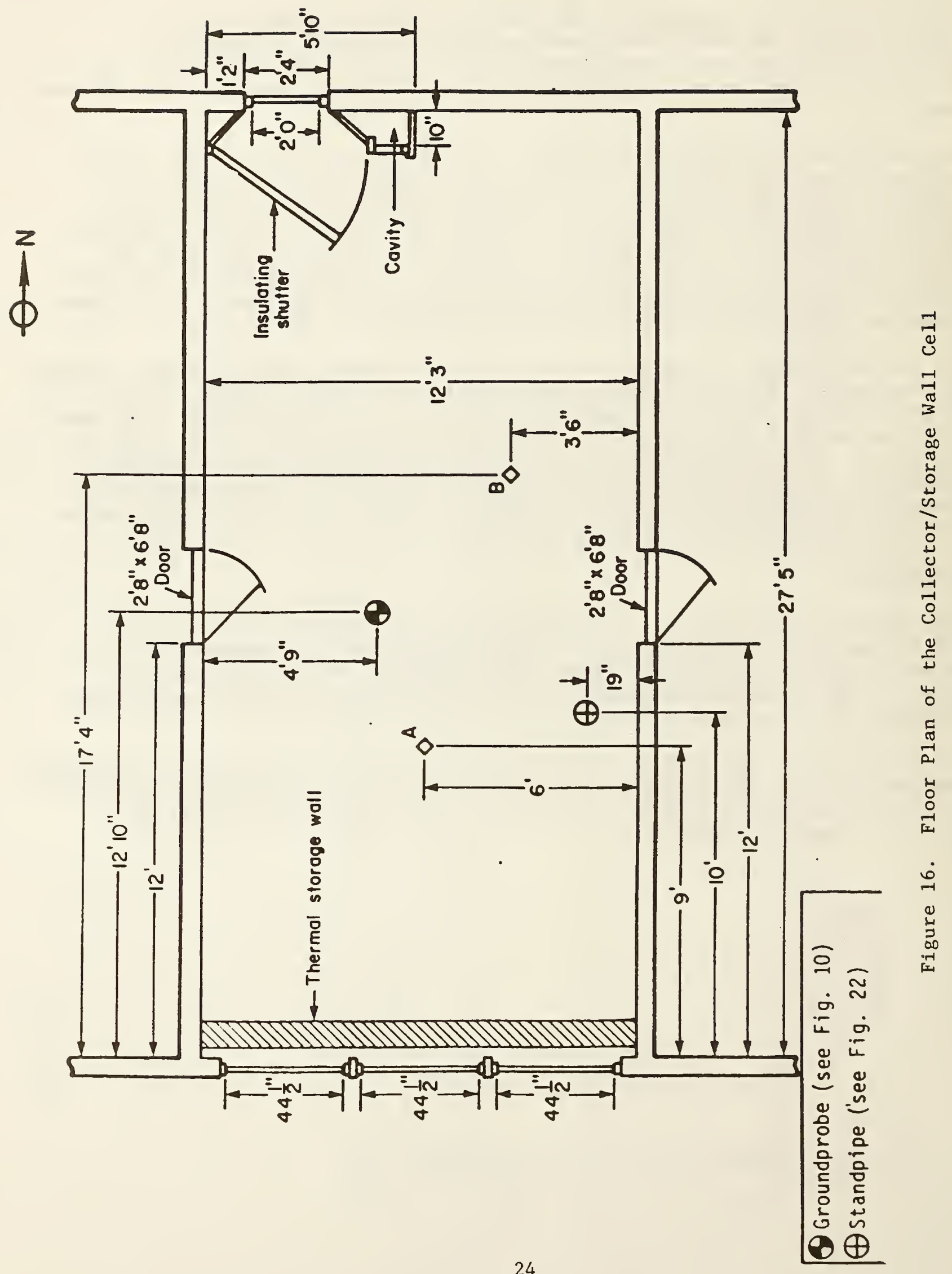




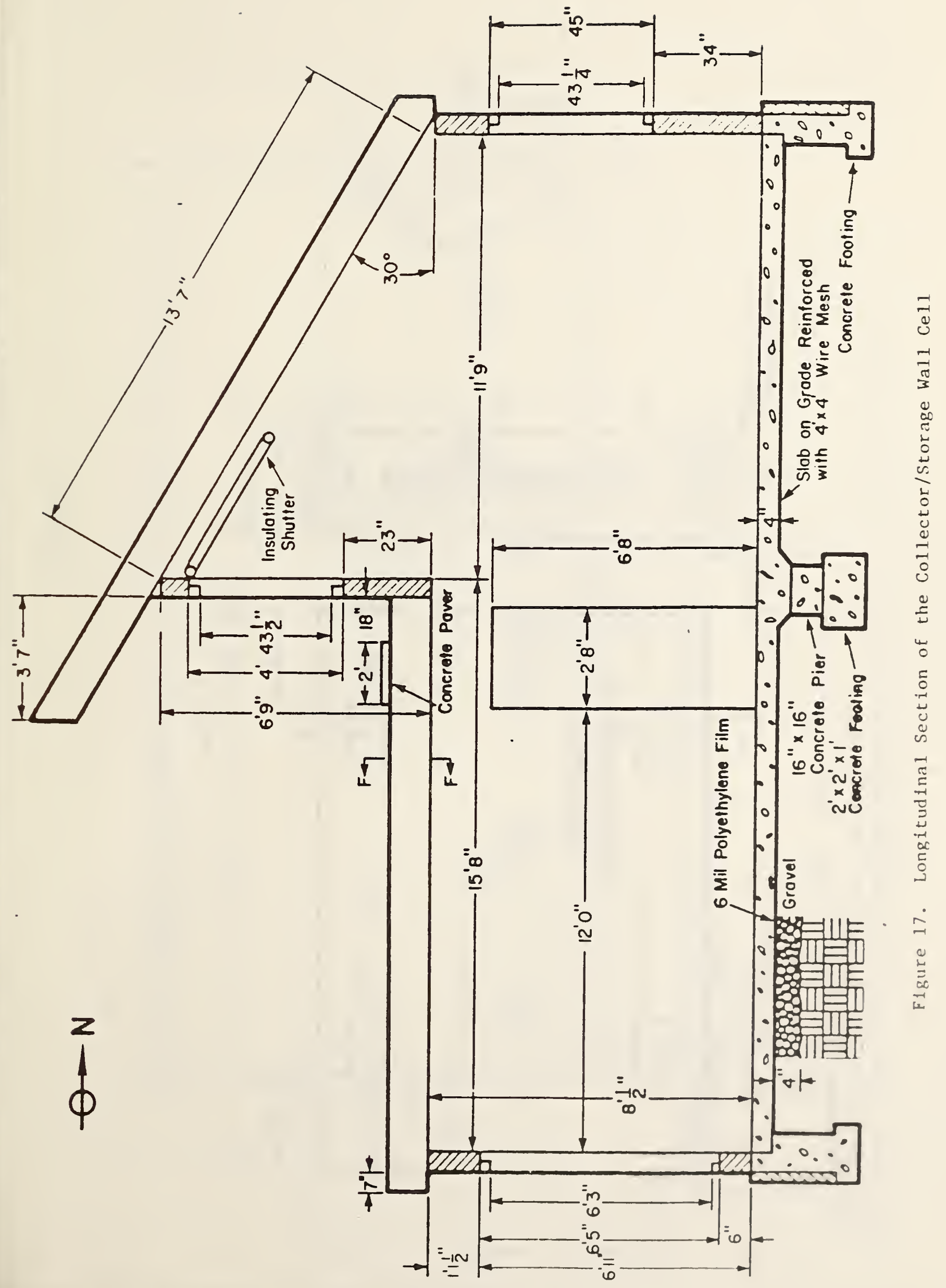




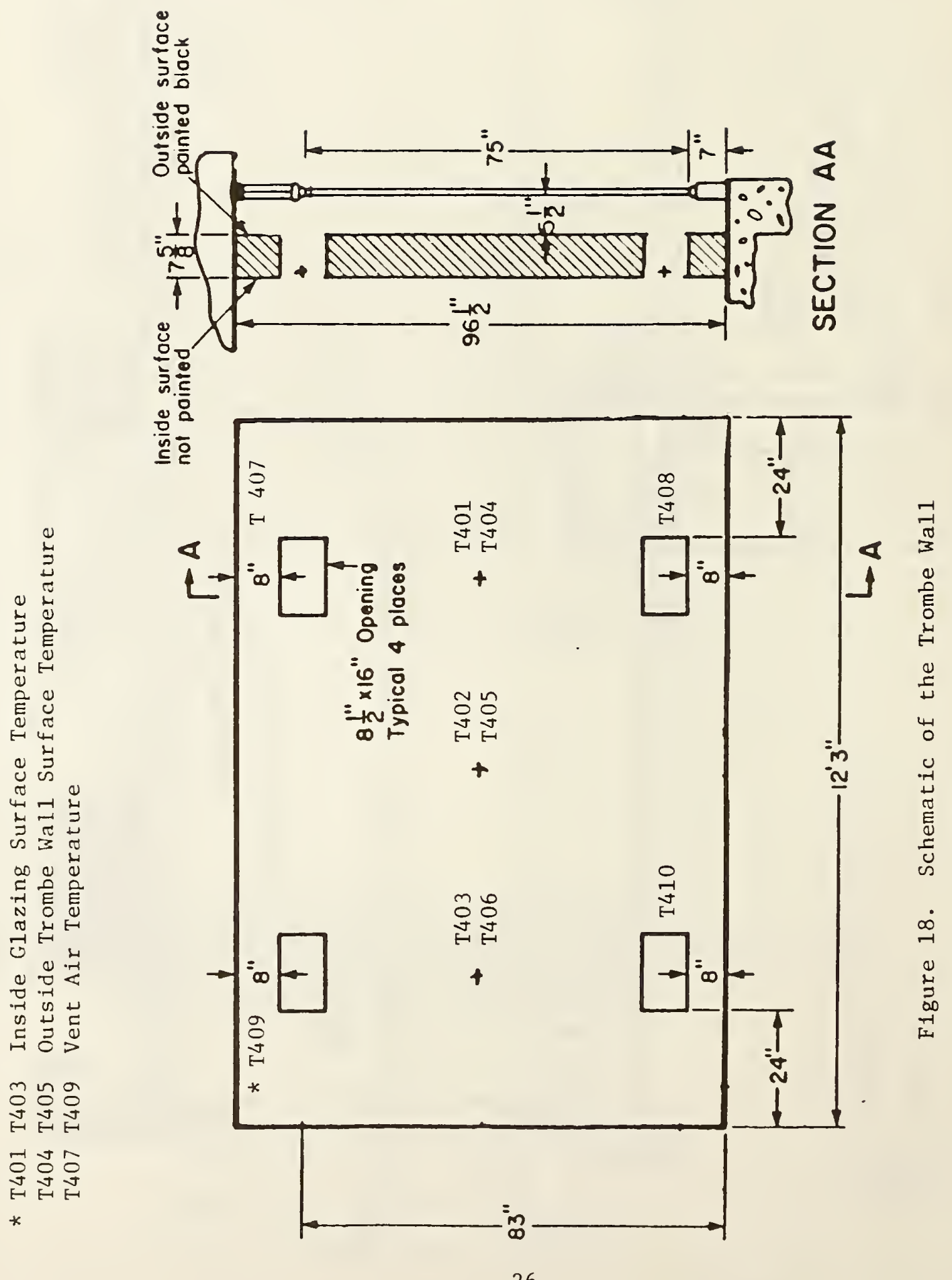




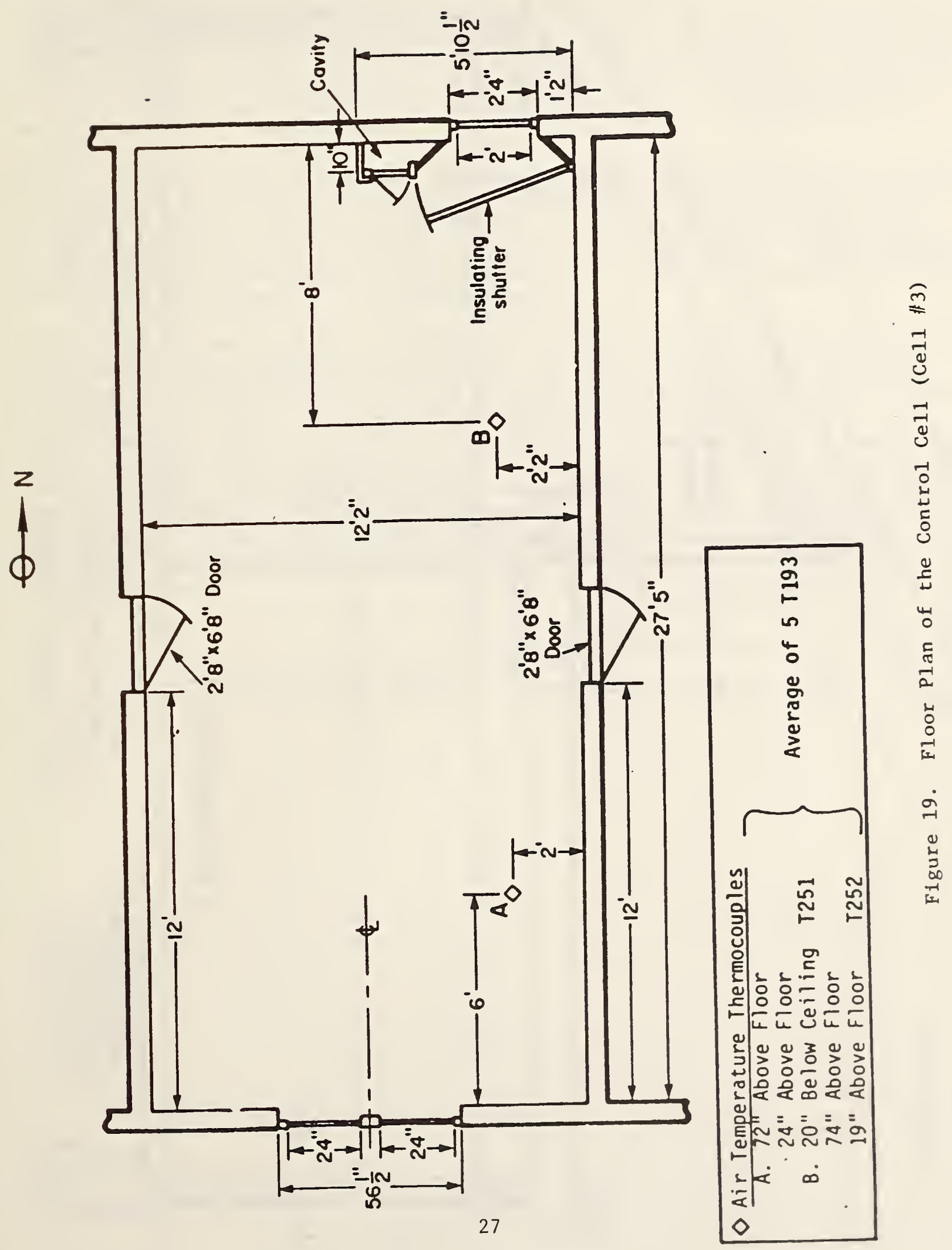




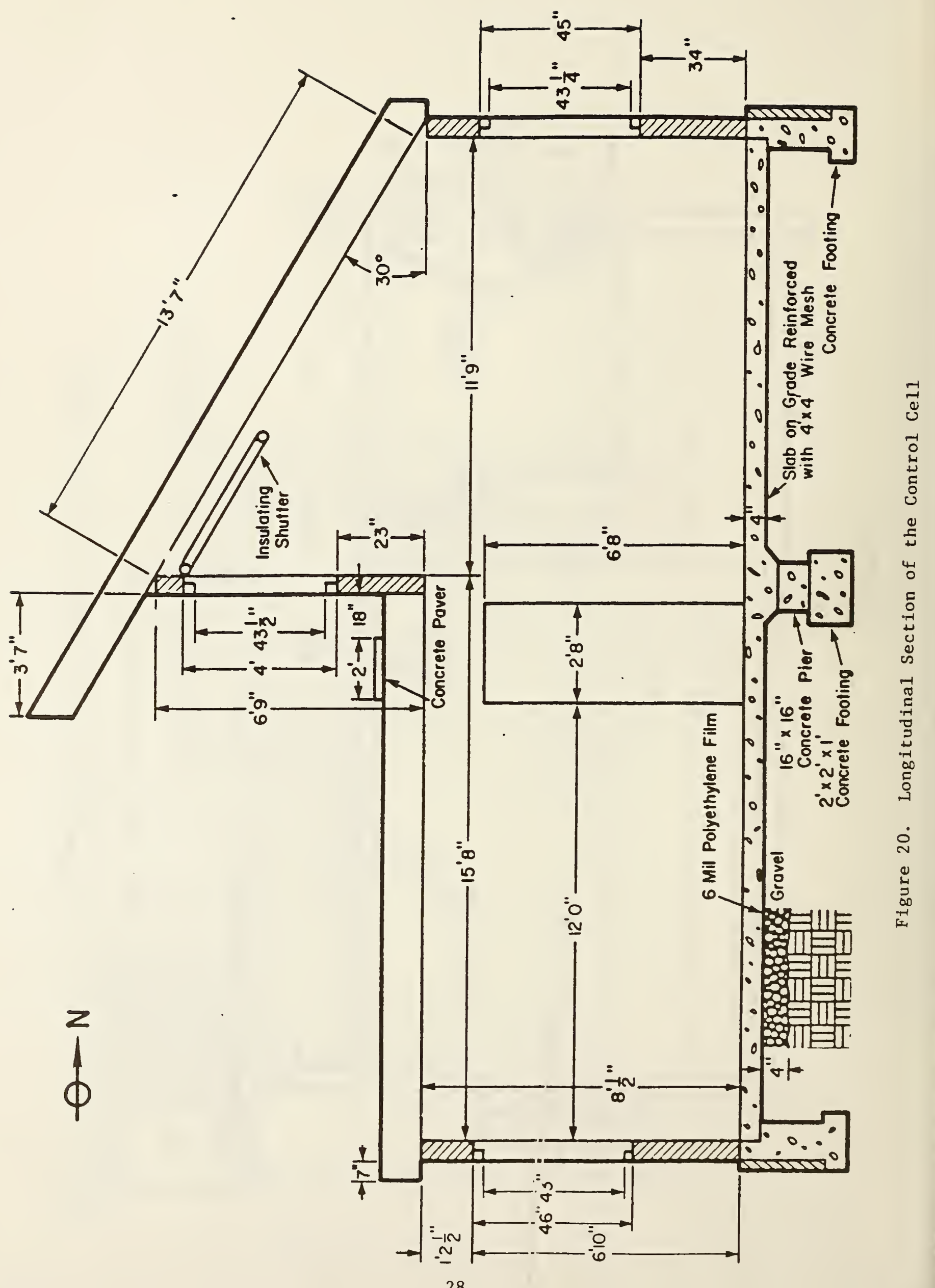




\section{Cell 非}

This is a direct gain fenestration cell. A floor plan of the cell is shown in figure 21, and a longitudinal view is shown in figure 22. Note that there are four removable concrete floor sections bordered with paper joints. The purpose of these sections is to allow for the future addition of an underground rock storage or any other configuration modifications. Cell 非 4 is separated from cell 非 3 by a heavy metal door.

The direct gain fenestration is a double-pane wood sliding glass door covering the entire width of the lower south wall. The sliding glass door consists of two fixed sections and one sliding section. All three sections are of equal area. The total unobstructed glass area is $6.27 \mathrm{~m}^{2}\left(67.53 \mathrm{ft}^{2}\right)$. The properties of the glass have been summarized in figure 13. As indicated earlier the upper level south wall contains a clerestory window.

Besides the thermal storage provided by the concrete floor, this cell contains additional thermal storage in the form of a $2.08 \mathrm{~m}(6.83 \mathrm{ft}$ ) wide by $2.46 \mathrm{~m}$ $(8.08 \mathrm{ft}$ ) high by $200 \mathrm{~mm}$ ( $8 \mathrm{in}$ ) thick concrete masonary unit (CMU) wall located inside the north wall. The cores of the CMU's are filled with mortar, the same material as used for Trombe wall in cell 非. A section view of the thermal storage wall is shown in figure 23. The surfaces of the thermal storage wall are unpainted. A description of the direct gain cell, i.e., cell 非, is also available in reference 7. However, references 1 and 5 do not contain any infor mation on the new data acquisition system, air infiltration monitoring system, and the sensors installed in cells 非2, 非, and 非 4 in FY83 and FY84. 


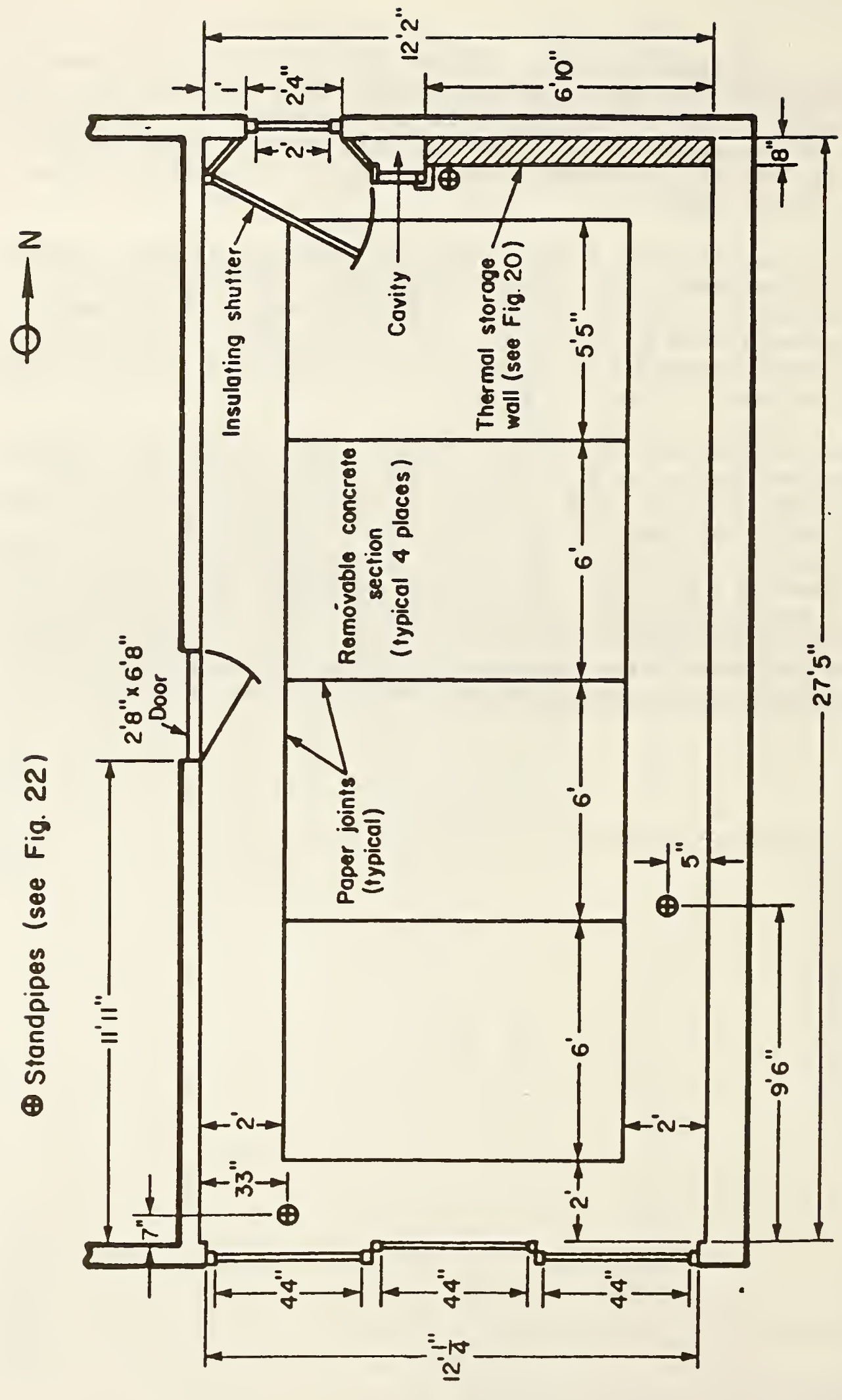

 
Thermal Resistance

(at framing)
Thermal Resistance

(befween froming)
Heat

Copocity

Surface $a_{s}=.76$

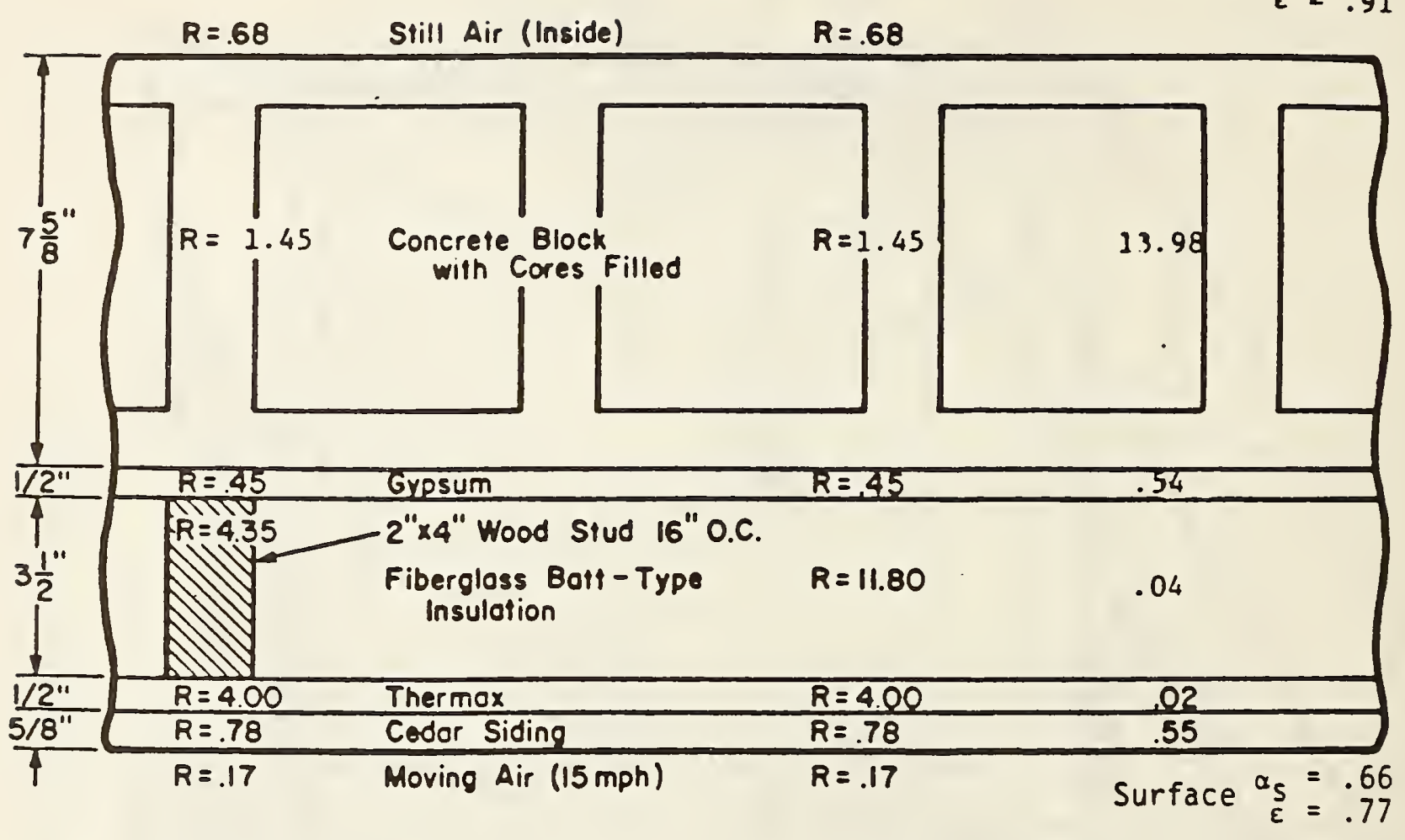

$$
\begin{array}{|l}
R_{\mathrm{s}}=11.83 \\
\text { Areo }=15 \%
\end{array} \quad \begin{aligned}
& R_{\mathrm{i}}=19.33 \\
& \text { Areo }=85 \%
\end{aligned} \quad \begin{array}{r}
\frac{m C_{p}}{A}=15.13 \mathrm{Btu} / \mathrm{ft} 2{ }^{\circ} \mathrm{F} \\
\left(3092 \mathrm{KJ} / \mathrm{m}^{2} \circ \mathrm{C}\right)
\end{array}
$$$$
U_{A V}=\frac{.15}{11.33}+\frac{.85}{19.33}=\begin{array}{ll}
.0567 & B t u / \mathrm{ft}^{2} \mathrm{hr}^{\circ} \mathrm{F} \\
\left(.3213 \quad \mathrm{~W} / \mathrm{m}^{20} \mathrm{C}\right)
\end{array}
$$$$
R_{A V}=\begin{aligned}
& 17.65 \mathrm{ft}^{2} \mathrm{hr} O \mathrm{~F} / \mathrm{Btu} \\
& \left(3.112 \mathrm{~m}^{2} \mathrm{C} / \mathrm{W}\right)
\end{aligned}
$$

Note: Although the studs are 16" from center to center, in calculating $R$ values, they are assumed to occupy $15 \%$ of the wall area in order to compensate for multidirectional heat flow and because of the additional studs used in corners and as top and bottom plates.

Figure 23: Cross Section of the Thermal Storage Wall 


\subsection{MATERIALS PROPERTIES AND HEAT LOSS COEFFICIENTS OF THE TEST CELLS}

Properties of various building materials are summarized in table 2 and 3 . These properties, when not measured, are taken from the ASHRAE Handbook of Fundamentals, 1981. Although the values of thermal resistance and heat capacity are given to two decimal places it should be noted that this degree of accuracy is not necessarily known. In fact, the material properties can vary with ambient temperature and humidity, as well as with the age of the products. Also there is an uncertainty in the fraction of the wall area that is occupied by wood framing (see the note at the bottom of figures 7,8 , and 23 .

In determining a total $\mathrm{R}$-value for the wall, a thermal resistance of $.03 \mathrm{~m}^{2 \circ} \mathrm{C} / \mathrm{W}$ (.17 $\mathrm{ft}^{2} \mathrm{hr}^{\circ} \mathrm{F} / \mathrm{Btu}$ ) was chosen for "moving air" on the outside wall surfaces. This corresponds to a wind speed of $24 \mathrm{~km} / \mathrm{h}$ suggested by ASHRAE for winter calculations. (The thermal resistance suggested for summer is .044 corresponding to a wind speed of $12 \mathrm{~km} / \mathrm{h}$.) Some users of this manual may want to substitute a different value corresponding to the actual measured wind speed. Another "correction" that some users may want to include is the fact that $12.7 \mathrm{~mm}$ plywood was used instead of Thermax sheathing within $1.2 \mathrm{~m}$ of all exterior corners for structural purposes. (Thus, the $\mathrm{R}$-value of .704 should be replaced by an $\mathrm{k}$-value of 11 for the corners of the building.)

The values of overall heat loss coefficient "UA" for various components or heat transfer surfaces of cells 非, 非, and 非 4 are estimated by using the ASHRAE steady-state method and the material properties discussed above. The values of "UA" are presented in table 4.

\subsection{HEATING, VENTILATING, AND AIR-CONDITIONING SYSTEM}

Auxiliary heating and cooling is provided with a fan coil unit installed in each cell under the north window. The location of the fan coil unit is shown in figure 10. Heating is provided by a $3.76 \mathrm{~kW}, 208 \mathrm{~V}$ electric heater in the fan coil unit. Cooling is provided by diverting the flow of fluid to the cooling coil of the fan coil unit. The flow of the chiller fluid from the bypass loop is diverted by a solenoid control diverter valve which is actuated by the cooling thermostat. The chiller fluid, a 50-50 water and propylene glycol solution, is chilled by a $2.64 \mathrm{~kW}$ air cooled chiller.

The space temperature in each cell is controlled by positive off-setting thermostats with $\pm 0.5^{\circ} \mathrm{C}$ deadbands. Each cell has two thermostats, one for cooling and the other for heating. The power supply to the heater and diverter valve can be cut off if desired. Also the power supply to the heater and the diverter valve is wired via an interlock system so that the auxiliary heating and cooling cannot by supplied simultaneously.

In addition, two destratifying fans are placed near the center of the floor of cell 非. One fan takes the room air from the floor level and discharges it at the sloped ceiling level near the clerestory window; and the other fan does the reverse. The combined action of the two fans causes the room air to mix and reduce stratification. 
Table 2. Material Propertiesa

(SI Un1 t8)

\begin{tabular}{|c|c|c|c|c|c|c|}
\hline MATERIALS & $a_{8}$ & $\varepsilon$ & $\left(w / m-{ }^{\circ} \mathrm{C}\right)$ & $\left(\mathrm{kg} / \mathrm{m}^{3}\right)$ & $\begin{array}{c}\mathrm{C}_{\mathrm{p}} \\
\left(\mathrm{J} / \mathrm{kg}-{ }^{\circ} \mathrm{C}\right)\end{array}$ & $\left(m^{2}-^{R} \mathrm{C} / \mathrm{w}\right)$ \\
\hline Gypsum board $(127 \mathrm{~cm})$ & $0.23 c$ & $0.78 \mathrm{c}$ & 0.161 & 801 & 1089 & 0.079 \\
\hline Gypsum board $(1.59 \mathrm{~cm})$ & $0.23 \mathrm{c}$ & $0.78 \mathrm{C}$ & 0.161 & 801 & 1089 & 0.099 \\
\hline $\begin{array}{l}\text { Themax }(1.27 \mathrm{~cm})^{0}-\text { foll- } \\
\text { backed polyurethane board }\end{array}$ & - & -- & 0.017 & 28.8 & 837 & 0.704 \\
\hline Cedar siding $(1.59 \mathrm{~cm})$ & $0.66^{c}$ & $0.77 \mathrm{c}$ & 0.115 & 513 & 1382 & 0.137 \\
\hline Concrete slab $(13.72 \mathrm{~cm})$ & $0.67 c$ & $0.92^{c}$ & $1.42^{\mathrm{C}}$ & $2243 c$ & 837 & $0.072 \mathrm{c}$ \\
\hline $\begin{array}{l}\text { CMU storage wall }(19.37 \mathrm{~cm}) \\
\text { Fiberglass batt }\end{array}$ & $0.76^{\mathrm{C}}$ & $0.91^{c}$ & $0.76^{d}$ & $1762^{d}$ & 837 & $0.255^{d}$ \\
\hline $\begin{array}{l}\text { Insulation }(8.89 \mathrm{~cm}) \\
\text { Fiberglass batt }\end{array}$ & - & -- & 0.043 & 9.6 & 837 & 2.08 \\
\hline Insulation $(15.24 \mathrm{~cm})$ & - & -- & 0.025 & 9.6 & 837 & 3.59 \\
\hline $\begin{array}{l}\text { Extruded polystyrene }(5.05 \mathrm{~cm}) \\
\text { Extruded polystyrene }\end{array}$ & -- & -- & 0.029 & 28.8 & 1214 & 1.76 \\
\hline$(1.91 \mathrm{~cm})$ & - & - & 0.029 & 28.8 & 1214 & 0.660 \\
\hline Sol1 (Dry) & 0.20 & 0.90 & $\sim 0.35$ & 721 & 1842 & - \\
\hline P1 ywood $(1.27 \mathrm{~cm})$ & -- & -- & 0.115 & 545 & 1214 & 0.109 \\
\hline P1 ywood $(1.91 \mathrm{~cm})$ & - & - & 0.115 & 545 & 1214 & 0.164 \\
\hline Asphalt shingles & 0.90 & 0.90 & - & 1121 & 1256 & 0.077 \\
\hline$(4.45 \mathrm{~cm})$ & 0.60 & 0.90 & 1.44 & 888 & 1675 & 0.030 \\
\hline Wood $(8.81 \mathrm{~cm})$ & - & - & 0.155 & 513 & 1382 & 0.329 \\
\hline $\begin{array}{l}\text { Interior metal door } \\
(4.45 \mathrm{~cm})\end{array}$ & -- & & & & & \\
\hline Louvered door d & - & 0.90 & 0.097 & $\begin{array}{l}881 \\
224\end{array}$ & $\begin{array}{r}544 \\
1382\end{array}$ & 0.44 \\
\hline Gravel (10.16 cm layer & 标 & 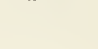 & 0.070 & 264 & 1302 & 0.10 \\
\hline beneath floor slab) & - & -- & 1.44 & 881 & 1675 & 0.070 \\
\hline
\end{tabular}

Movable Insulation - thermal resistance - $1.23 \mathrm{~m}^{2}{ }^{\circ} \mathrm{C} / \mathrm{W}$

Schedule - In place sundown to sunrise (operated manually)

\footnotetext{
a Material properties are taken from ASHRAE Handbook of Fundamentals, 1981, except as otherwise noted. Several of these values will be replaced by measured values as they become avallable.

b Material properties estimated.

c Properties measured.

d Properties measured for mortar in cores and for remainder of CMU block; Composite CMU block value calculated from these properties.
} 
Table 3. Material Propertiesa

(English UnIts)

\begin{tabular}{|c|c|c|c|c|c|c|}
\hline MATERIALS & $a_{8}$ & $\varepsilon$ & $\begin{array}{c}k \\
\left(\mathrm{Btu} / \mathrm{h}-\mathrm{ft}--^{\circ} \mathrm{f}\right)\end{array}$ & $\left(1 \mathrm{~b} / \mathrm{ft}^{3}\right)$ & $\left(\mathrm{Btu} / \mathrm{P}_{b-}{ }^{\mathrm{C}_{\mathrm{F}}}\right.$ & $\left(h-f t^{2}=^{\circ} \mathrm{g} / \mathrm{Btu}\right)$ \\
\hline Gypsum board $(0.5 \mathrm{in})$ & $0.23^{c}$ & $0.78^{c}$ & 0.093 & 50.0 & .26 & 0.45 \\
\hline $\begin{array}{l}\text { Gypsum board }(0.631 \mathrm{n}) \\
\text { Therax }\left(0.51 \mathrm{n}^{\mathrm{b}}\right)^{\mathrm{b}}-\text { fo1l- }\end{array}$ & $0.23^{c}$ & $0.78^{c}$ & 0.093 & 50.0 & .26 & 0.56 \\
\hline backed polyurethane board & - & - & 0.010 & 1.8 & .20 & 4.00 \\
\hline Cedar siding $(0.63 \mathrm{In})$ & $0.66^{c}$ & $0.77^{c}$ & 0.0667 & 32.0 & .33 & 0.78 \\
\hline Concrete $\mathrm{lab}(0.45 \mathrm{ft})$ & $0.67 \mathrm{c}$ & $0.92^{c}$ & $0.82^{c}$ & $140^{c}$ & .20 & $0.41^{\mathrm{c}}$ \\
\hline CMU storage wall $(7.63 \mathrm{In})$ & $0.76^{\mathrm{C}}$ & $0.91 \mathrm{C}$ & $0.44^{d}$ & $110^{\mathrm{d}}$ & .20 & $0.45^{d}$ \\
\hline Plberglas batt & & & & & & \\
\hline Insulation $(3.5 \mathrm{ln})$ & - & 一 & 0.025 & 0.6 & .20 & 11.8 \\
\hline Flberglass batt & & & & & & \\
\hline Insulation ( 6 in) & - & 一 & 0.0250 & 0.6 & .20 & 20.4 \\
\hline Extruded polystyrene (2 $1 \mathrm{n}$ ) & 一 & - & 0.017 & 1.8 & .29 & 10.0 \\
\hline Extruded polystyrene & & & & & & \\
\hline$(0.75 \mathrm{in})$ & - & - & 0.017 & 28.8 & .29 & 3.75 \\
\hline Sol1 (dry) & 0.20 & 0.90 & $\sim 0.20$ & 45 & .44 & - \\
\hline Plywood $(0.5 \mathrm{ln})$ & - & - & 0.0667 & 34 & .29 & 0.62 \\
\hline Plywood $(0.75 \mathrm{1n})$ & - & 一 & 0.9667 & 34 & .29 & 0.93 \\
\hline Asphalt shingles & 0.90 & 0.90 & - & 70 & .30 & 0.44 \\
\hline Roof, gravel or slag & & & & & & \\
\hline$(1.75 \mathrm{in})$ & 0.60 & 0.90 & 0.834 & 55 & .40 & 0.17 \\
\hline Wood $(1.5 \mathrm{ln})$ & - & - & 0.0667 & 32 & .33 & 1.87 \\
\hline Interfor metal door & & & & & & \\
\hline$(1.75 \mathrm{1n})$ & 一 & 0.90 & 0.056 & 55 & .13 & 0.44 \\
\hline Louvered door $b$ & 一 & - & 0.045 & 14 & .33 & 1.0 \\
\hline Gravel ( $10.16 \mathrm{~cm}$ layer & & & & & & \\
\hline beneath floor $\mathrm{alab}$ ) & - & - & 0.834 & 55 & .40 & 0.40 \\
\hline
\end{tabular}

Movable Insulation - thermal resistance - $7.0 \mathrm{~h}-\mathrm{ft}^{2}-{ }^{\circ} \mathrm{F} / \mathrm{Btu}$

Schedule - In place sundown to sunrise (operated manually)

a Materlal propertles are taken from ASHRAE Handbook of Fundamentals, 1981, except as otherwise noted. Several of these values w11l be replaced by measured values as they becone avallable.

b Material properties estimated.

c Properties measured.

d Properties measured for mortar in cores and for remainder of CMU block; Composite CMU block value calculated from these properties. 
Table 4. Values of Overall Heat Loss Coefficient (UA) Estimated by ASHRAE Steady-State Method.

\begin{tabular}{|c|c|c|c|c|}
\hline \multirow[t]{2}{*}{ Item 非 } & \multirow{2}{*}{$\begin{array}{l}\text { Component or } \\
\text { Heat Transfer } \\
\text { Surface }\end{array}$} & \multicolumn{3}{|c|}{$\begin{array}{l}\text { Overall Heat Loss Coefficient (UA) } \mathrm{W} /{ }^{\circ} \mathrm{C} \\
\left(\mathrm{Btu} / \mathrm{hr}-{ }^{\circ} \mathrm{F}\right)\end{array}$} \\
\hline & & Cel1 \#2 & Cell 非3 & Ce11 非 \\
\hline 1. & Ceiling & $5.78(3.05)$ & $5.78(3.05)$ & $5.78(3.05)$ \\
\hline 2. & Floor & $4.70(2.48)$ & $4.70(2.48)$ & $10.10(5.33)$ \\
\hline 3. & East wall & $0.00 *$ & $0.00 *$ & $4.92(2.60)$ \\
\hline 4. & West wall & $0.00 *$ & $0.00 *$ & $0.00 *$ \\
\hline 5. & North wall & $3.49(1.84)$ & $3.49(1.84)$ & $3.49(1.48)$ \\
\hline 6. & $\begin{array}{l}\text { Upper level south } \\
\text { wall with clere- } \\
\text { story shutter: }\end{array}$ & & & \\
\hline & $\begin{array}{l}\text { a. closed } \\
\text { b. open }\end{array}$ & $\begin{array}{cc}4.23 & (2.23) \\
18.0 & (9.50)\end{array}$ & $\begin{array}{cc}4.23 & (2.23) \\
18.0 & (9.50)\end{array}$ & $\begin{array}{cc}4.23 & (2.23) \\
18.0 & (9.50)\end{array}$ \\
\hline 7. & $\begin{array}{l}\text { Lower level south } \\
\text { wall. }\end{array}$ & $14.45(7.63)$ & $9.58(5.06)$ & $28.15(14.8)$ \\
\hline
\end{tabular}

* The UA value of the inside partition walls is equal to $7.95 \mathrm{~W} /{ }^{\circ} \mathrm{C}(4.20 \mathrm{Btu} / \mathrm{hr}-$ ${ }^{\circ} \mathrm{F}$ ). However, for the purpose of estimated UA value for the test cells the inside partition walls are considered to have a UA value of zero. This is so because the cell temperatures for the duration of an experiment, are nearly equal and the intercell heat transfer is neglible in comparison to heat transfer through the other surfaces. 
A total of 457 sensors are installed in and around the building. There are 26 sensors outside the building, and $6,173,26$, and 226 , respectively, are in cell 非, cell 非, cell 非, and cell 非. These include flow meters, heat flux meters, pyronometers, resistance thermometers, thermocouples, watt-hour meters, and weather sensors. The general location of these sensors is summarized in table 5 .

The sensors in this handbook are labeled by a letter and a number. The letters include $\mathrm{H}$ (radiation), $\mathrm{Q}$ (heat $\mathrm{flux}$ ), $\mathrm{R}$ (resistance thermometer), $\mathrm{T}$ (temperature), W (weather), and WH (watt-hour). The number, for the sensors installed prior to FY83, correspond to the sensor in references 1 and 5. The sensors labeled $\mathrm{T} 267$ to $\mathrm{T} 271$ in cell $\left.\right|^{2} 2$ in reference 1 have been removed and replaced by new sensors. The sensors labeled T400 to T520 were installed in FY83 and FY84. The details of the sensor locations are described below.

\subsection{OUTSIDE THE BUILDING}

There are 4 solar radiation sensors, a ground reflectance sensor, a wind speed and wind direction sensor, and 19 thermocouples outside the building.

A pyronometer (H215) mounted on the lower wall of cell $13,0.5 \mathrm{~m}$ (20 in) from the west of cell 非 and $1.2 \mathrm{~m}$ (48 in) above ground is used to measure total radiation on a south vertical surface. Two pyronometers mounted on the upper roof are used to measure sky irradiation (H216) and total horizontal radiation (H217). Ground reflectance is measured by an inverted pyronometer (H218) located about $4 \mathrm{~m}$ from the south wall and $5 \mathrm{~m}$ (197 in) from the east wall of the building. Normal beam radiation is measured by a pyrheliometer (H219) mounted on the lower roof.

The wind speed and wind direction is measured by an anemometer and vane system located about $61 \mathrm{~m}(200 \mathrm{ft})$ southwest of the test building.

Four mechanically aspirated and shielded thermocouples are used to measure the outside ambient air temperature. Two of these thermocouples, about $20 \mathrm{~mm}$ (.8 in) apart from each other, are about $1.2 \mathrm{~m}$ (48 in) above ground and about $2.5 \mathrm{~m}$ ( $99 \mathrm{in}$ ) south of the test building; the other two thermocouples are similarly situated on the north of the building. The location of these thermocouples is indicated in figure 1. A ground probe containing 12 thermocouples is used to monitor the ground temperature. The ground probe is located at a distance of $6.7 \mathrm{~m}(22 \mathrm{ft})$ from the northwest corner of the building. The location of the outside ground probe is indicated in figure 1, while the detalls are given in figure 24. The location of the thermocouples for monitoring the outside surface temperatures of east and north walls of cell $\$ 4$ are shown in figure 25 . 
Table 5. Various Sensors Installed at the NBS Passive Solar Test Facility

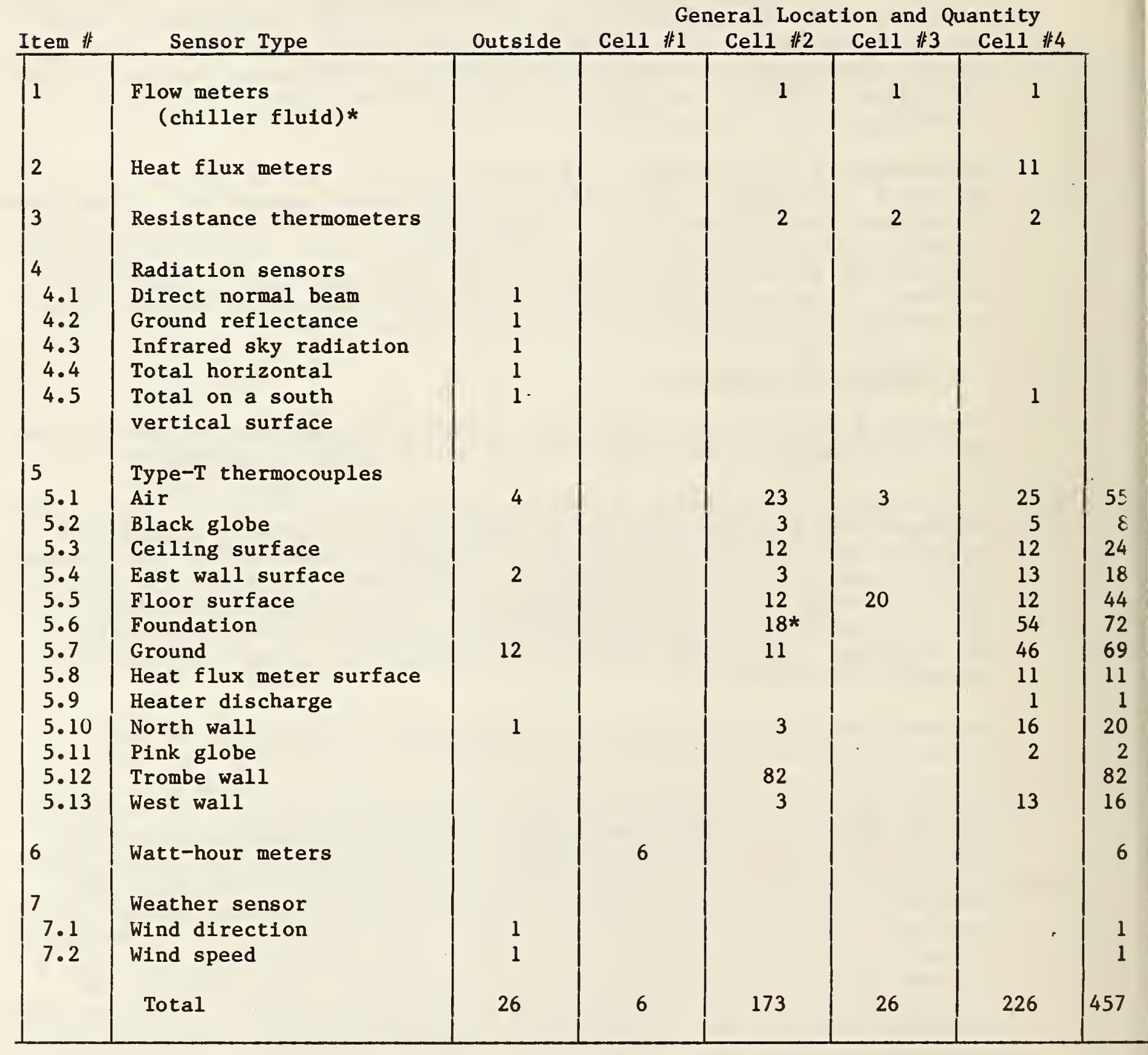

* Currently not monitored. 
Ground Probe Sensor Numbers

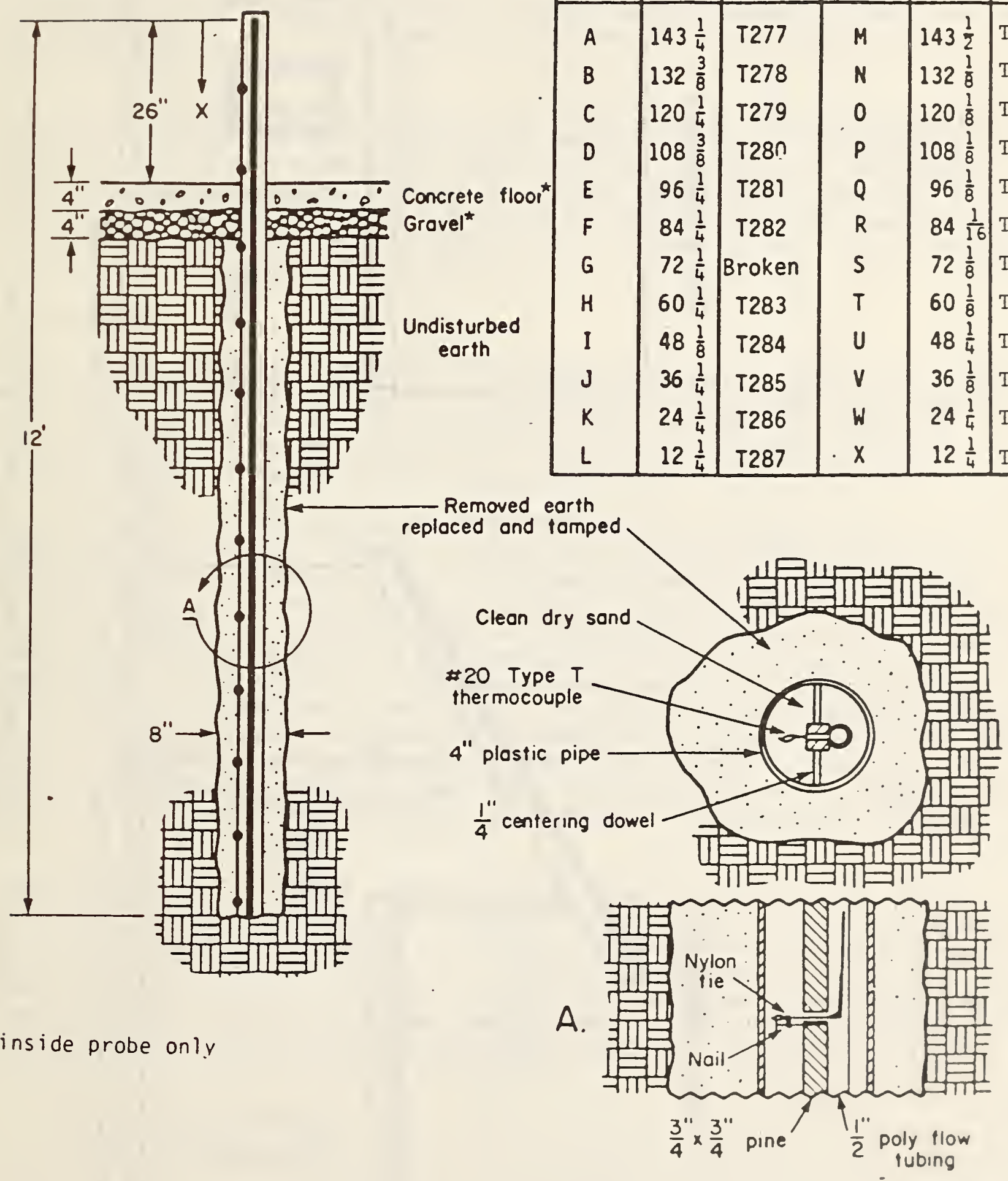

\begin{tabular}{|c|c|c|c|c|c|}
\hline \multicolumn{3}{|c|}{ Inside Probe } & \multicolumn{3}{c|}{ Outside Probe } \\
\hline Sensor & $x$ & Channe & Sensor & $x$ & Channe I \\
\hline A & $143 \frac{1}{4}$ & T277 & M & $143 \frac{1}{2}$ & T500 \\
B & $132 \frac{3}{8}$ & T278 & N & $132 \frac{1}{8}$ & T501 \\
C & $120 \frac{1}{4}$ & T279 & O & $120 \frac{1}{8}$ & T502 \\
D & $108 \frac{3}{8}$ & T28ก & P & $108 \frac{1}{8}$ & T503 \\
E & $96 \frac{1}{4}$ & T281 & Q & $96 \frac{1}{8}$ & T504 \\
F & $84 \frac{1}{4}$ & T282 & R & $84 \frac{1}{16}$ & T505 \\
G & $72 \frac{1}{4}$ & Broken & S & $72 \frac{1}{8}$ & T506 \\
H & $60 \frac{1}{4}$ & T283 & T & $60 \frac{1}{8}$ & T507 \\
I & $48 \frac{1}{8}$ & T284 & U & $48 \frac{1}{4}$ & T508 \\
J & $36 \frac{1}{4}$ & T285 & V & $36 \frac{1}{8}$ & T509 \\
K & $24 \frac{1}{4}$ & T286 & W & $24 \frac{1}{4}$ & T510 \\
L & $12 \frac{1}{4}$ & T287 & X & $12 \frac{1}{4}$ & T5II \\
\hline
\end{tabular}

Removed earth

Figure 24. Ground Temperature Probes

(See Figs. I and 16 for locations) 


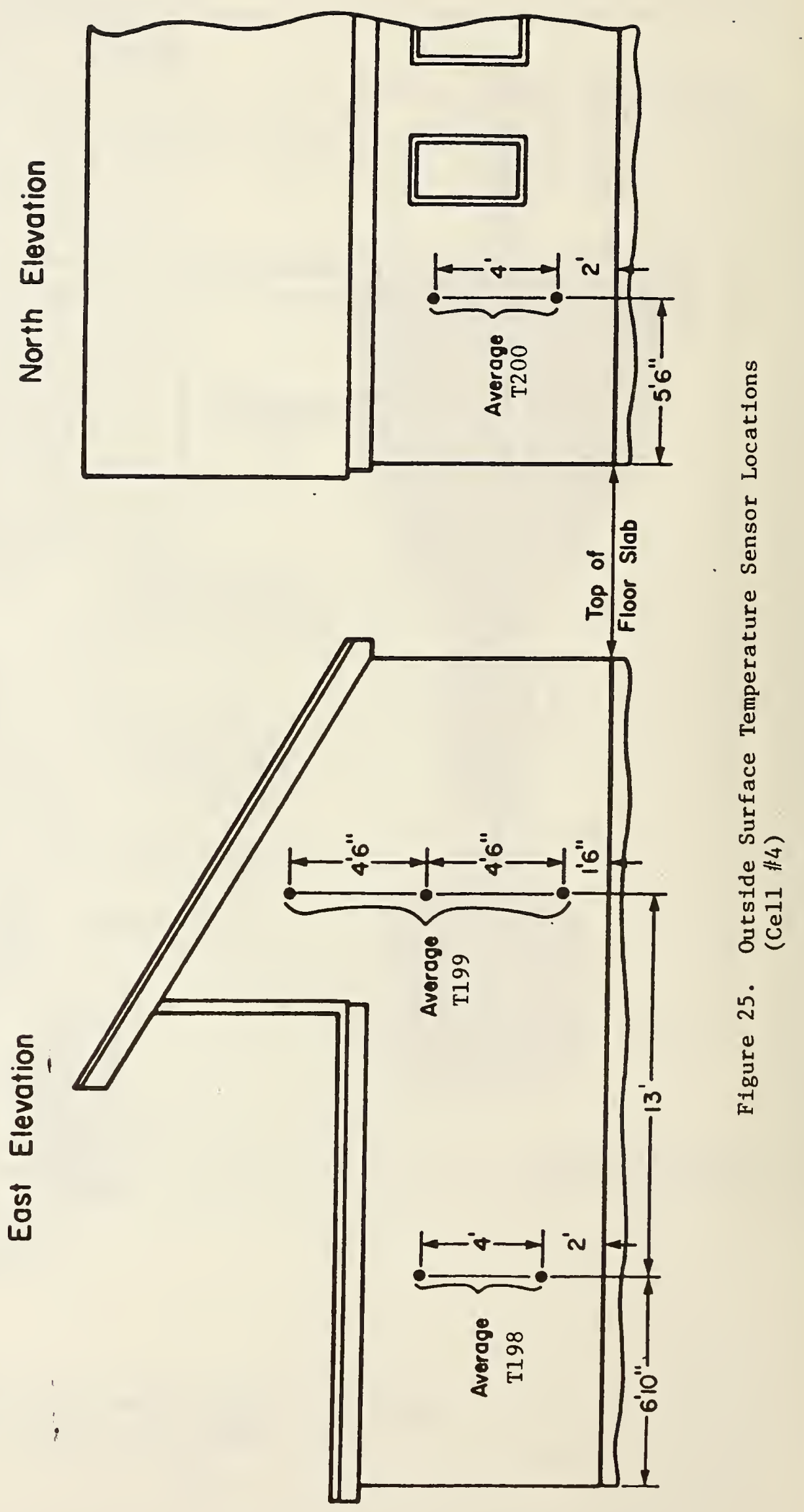




\subsection{CELL \# 1}

As indicated earlier, this cell houses the data acquisition system (DAS), and the continuous air infiltration monitoring system. All of the sensors are connected to the DAS in this cell.

This cell contains 6 watt-hour meters, labeled WHl to WH6, for monitoring the electrical energy supplied to cells $\#_{2}$, \#3, and 34 . There are two watt-hour meters for each of the three cells, one for the fan coll unit and one for the lights and electrical outlets. WH1, WH3, and WH5, respectively, are for the fan coll units in cell \#2, cell \#3, and cell \#4; and WH2, WH4, WH6, respectively, are for the lights and outlets in cell 非, cell 非, and cell 非 . Also a reference millivolt source is located in the cell \#1.

\subsection{CELL \#2}

There are 170 Type $T$ thermocouples, 2 resistance thermometers (RTD), and 1 flow meter placed in this cell. The flow meter, which is not currently monitored, is for measuring the chiller fluid flow rate flowing through the chiller of the fan coil unit. Two RTD's monitor the temperature of the chiller fluid entering (R231) and leaving (R232) the fan coil unit.

The location of the various thermocouples (TC) are shown schematically in figures 18, and 26 to 31. Figure 18 shows the location of $3 \mathrm{TC}$ 's on the inner surface of glazing, $3 \mathrm{TC}$ 's on the outer surface to Trombe wail, and $4 \mathrm{TC}$ 's in the vents (one in each vent) of the Trombe wall. Figure 26 shows the location of $63 \mathrm{TC}$ 's embedded in the Trombe wall and $9 \mathrm{TC}$ 's on the inside surface of the Trombe wall. Figure 27 shows the location of 22 shielded TC's for cell air temperatures, 3 TC's placed at the center of black globes, (one unshielded TC placed near the thermostats is not shown). A schematic of the radiation shield used for the thermocouples measuring air temperature in cells 非 and 非 4 is shown in figure 40. Figure 28 shows the location of $12 \mathrm{TC}$ 's on the floor surface and $12 \mathrm{TC}^{\prime} \mathrm{s}$ on the ceiling surface. Figures 29, 30, and 31, respectively, show the location of $3 \mathrm{TC}$ 's on the east wall, $3 \mathrm{TC}$ 's on the west wall, and 3 TC's on the north wall of cell 非.

In addition there is a ground probe in cell 非 2 which is similar to the ground probe situated outside of the test building. The location of the ground probe in cell \#2 is indicated in figure 15, while the location of the 11 TC's within the probe has been shown in figure 22. Also the cell contains a foundation probe containing $18 \mathrm{TC}$ 's, these thermocouples are not currently monitored. The location of the foundation probe has been indicated in figure 16, the details of the foundation probe and foundation sensor location is given in figure 37 along with the foundation sensors for cell \#4. 
STORAGE WALI SENSOR NHMEERS

\begin{tabular}{|c|c|c|c|c|c|c|c|c|}
\hline \multirow[b]{2}{*}{ Probe } & \multicolumn{7}{|c|}{ Depth Frow Inside Surface (Inch) cm } & \multirow{2}{*}{$\begin{array}{l}\text { Inside } \\
\text { Surface }\end{array}$} \\
\hline & $\begin{array}{l}19.05 \\
(7.50)\end{array}$ & $\begin{array}{l}17.46 \\
(6.88)\end{array}$ & $\begin{array}{l}13.65 \\
(5.38)\end{array}$ & $\begin{array}{l}9.84 \\
(3.88)\end{array}$ & $\begin{array}{l}6.03 \\
(2.38)\end{array}$ & $\begin{array}{l}2.22 \\
(0.88)\end{array}$ & $\begin{array}{l}0.32 \\
(0.13)\end{array}$ & \\
\hline $\begin{array}{l}1 \\
2 \\
3 \\
4 \\
5 \\
6 \\
7 \\
8 \\
9\end{array}$ & $\begin{array}{l}\text { T288 } \\
\text { T295 } \\
\text { T302 } \\
\text { T309 } \\
\text { T316 } \\
\text { T323 } \\
\text { T330 } \\
\text { T337 } \\
\text { T344 }\end{array}$ & $\begin{array}{l}\text { T289 } \\
\text { T296 } \\
\text { T303 } \\
\text { T310 } \\
\text { T317 } \\
\text { T324 } \\
\text { T331 } \\
\text { T338 } \\
\text { T345 }\end{array}$ & $\begin{array}{l}\text { T290 } \\
\text { T297 } \\
\text { T304 } \\
\text { T311 } \\
\text { T318 } \\
\text { T325 } \\
\text { T332 } \\
\text { T339 } \\
\text { T346 }\end{array}$ & $\begin{array}{l}\text { T291 } \\
\text { T298 } \\
\text { T305 } \\
\text { T312 } \\
\text { T319 } \\
\text { T326 } \\
\text { T333 } \\
\text { T340 } \\
\text { T347 }\end{array}$ & $\begin{array}{l}\text { T292 } \\
\text { T299 } \\
\text { T306 } \\
\text { T313 } \\
\text { T320 } \\
\text { T327 } \\
\text { T334 } \\
\text { T341 } \\
\text { T348 }\end{array}$ & $\begin{array}{l}\text { T293 } \\
\text { T300 } \\
\text { T307 } \\
\text { T314 } \\
\text { T321 } \\
\text { T328 } \\
\text { T335 } \\
\text { T342 } \\
\text { T349 }\end{array}$ & $\begin{array}{l}\text { T294 } \\
\text { T301 } \\
\text { T308 } \\
\text { T315 } \\
\text { T322 } \\
\text { T329 } \\
\text { T336 } \\
\text { T343 } \\
\text { T350 }\end{array}$ & $\begin{array}{l}\text { T465 } \\
\text { T466 } \\
\text { T467 } \\
\text { T462 } \\
\text { T463 } \\
\text { T464 } \\
\text { T459 } \\
\text { T460 } \\
\text { T461 }\end{array}$ \\
\hline
\end{tabular}

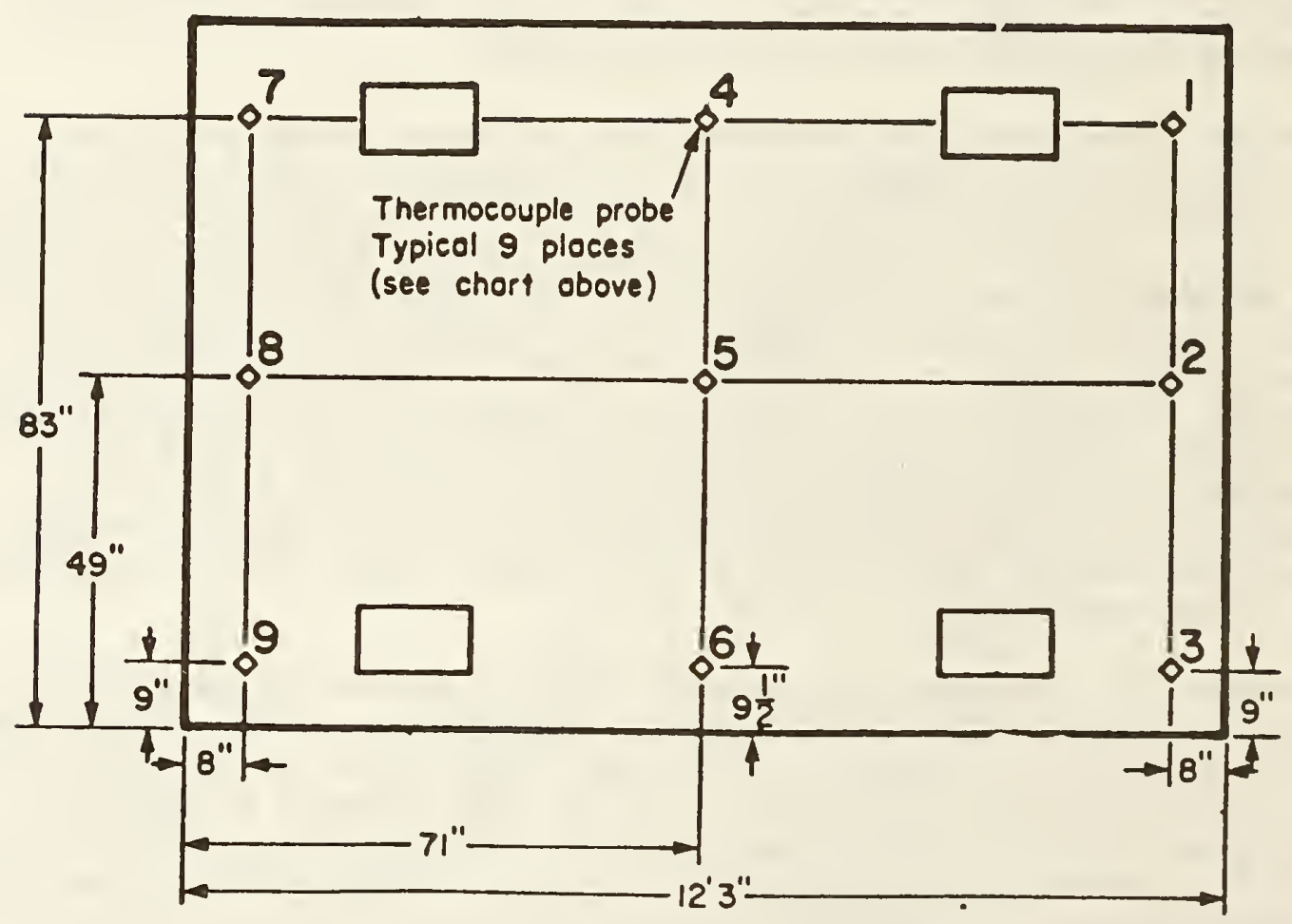

Figure 26. Trombe Wall Sensor Locations in Ce11 \#2 


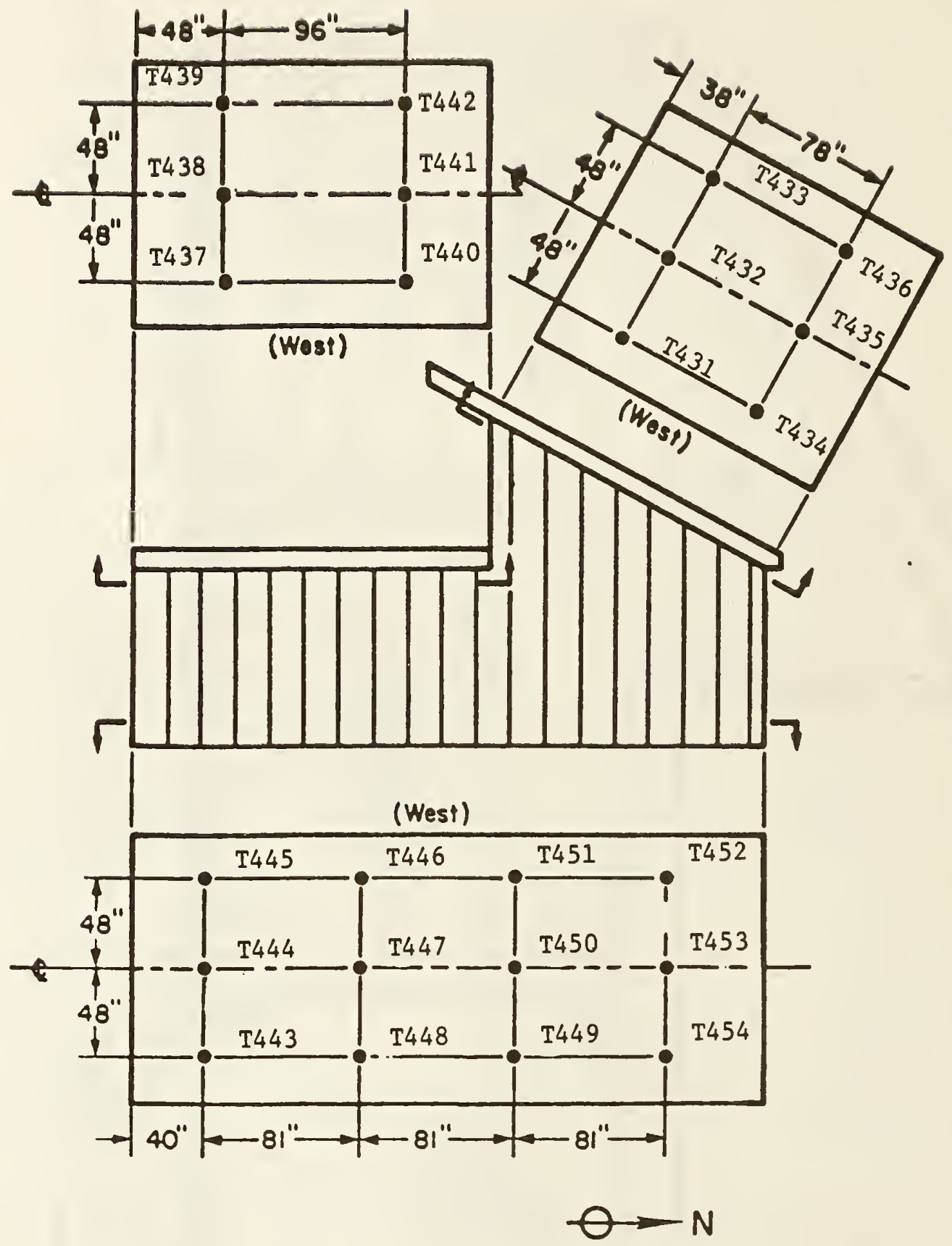

Figure 28. Sensor Locations Floor and Ceiling Cell \#2 


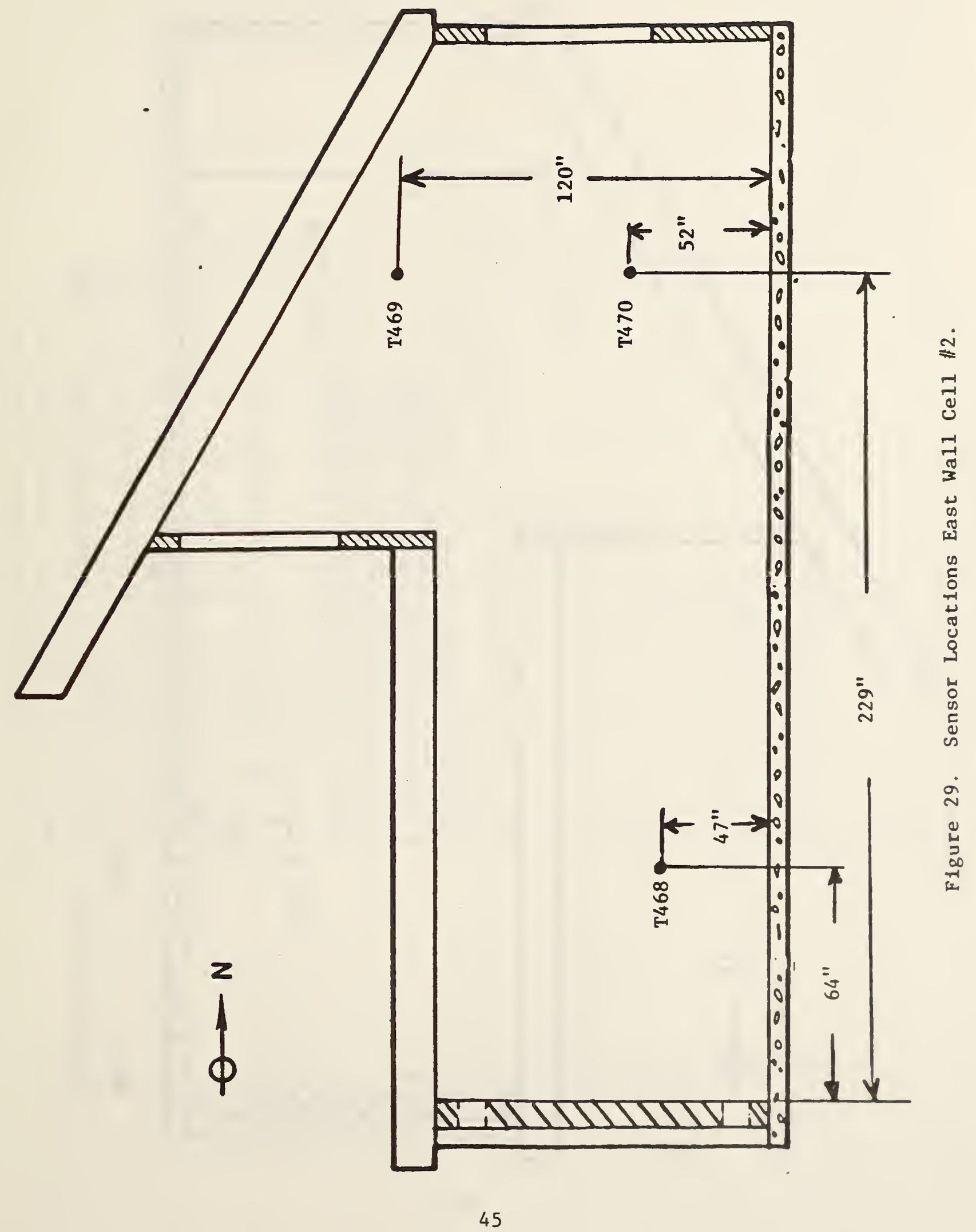




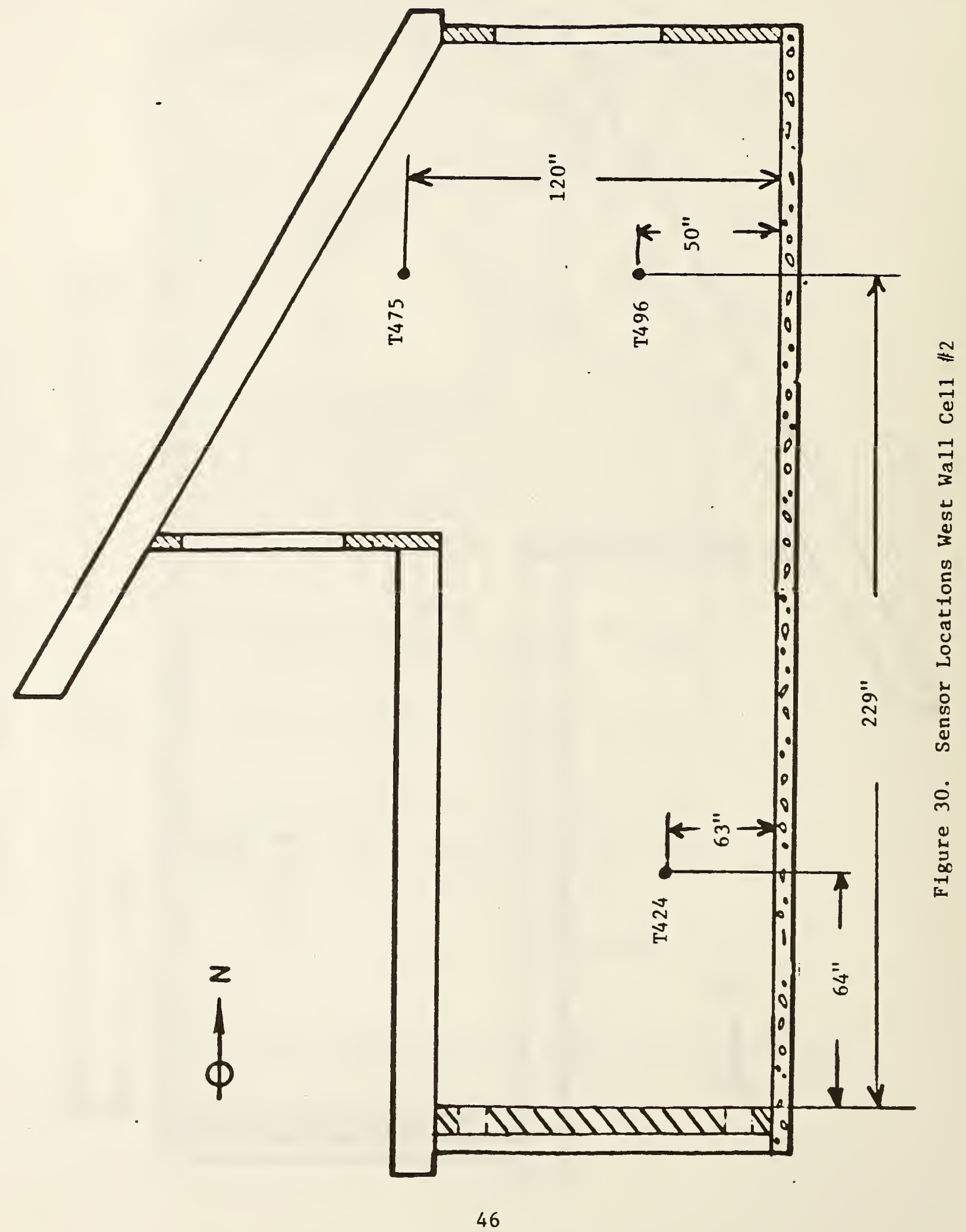




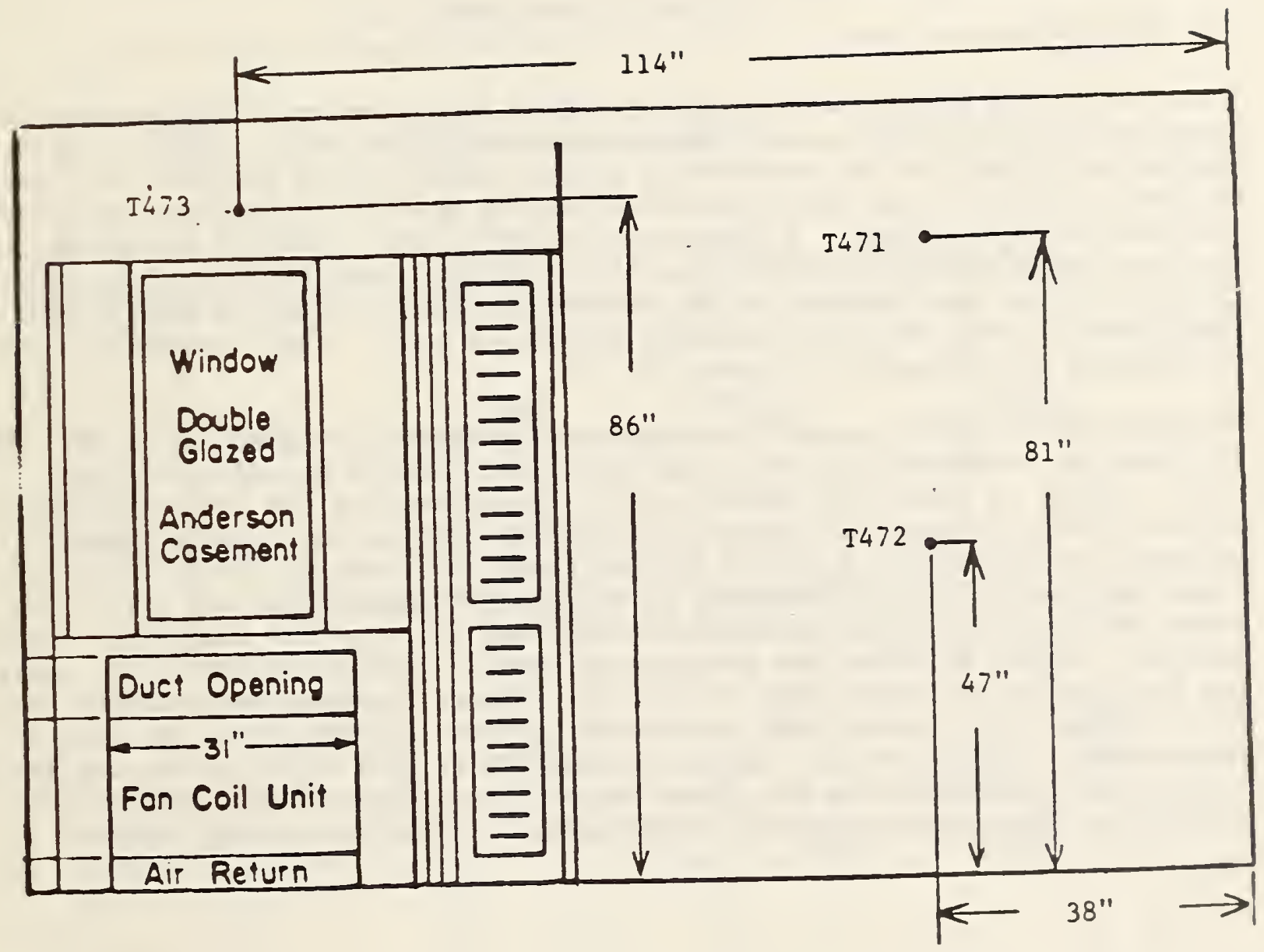

Figure 31. Sensor Locations North Wall Cell \#2 


\subsection{CELL \#3}

There are $20 \mathrm{TC}$ 's to monitor the floor surface temperature in cell \#3. Figure 32 schematically shows the location of these sensors. The air temperature in cell 3 is monitored at two locations with unshielded thermocouples, and averaged, see figure 19 for detalls.

The cell has 2 RTD for monitoring the temperature of the chiller fluid entering (R233) and leaving (R234) the fan coil unit. There also is a flow meter in the cell which is not currently monitored.

\subsection{CELL \#4}

There is a total of 226 sensors in this cell, 1 flow meter, 1 pyronometer, 11 heat flux meters, 3 RTD's, and 210 thermocouples. Two RTD's, R235 and R236, respectively, monitor the temperature of the chiller fluid entering and leaving the fan coil unit. The RTD labeled R237 is for monitoring the room air temperature near the themostats. A flow meter, which is not currently monitored, is for monitoring the flow rate of the chiller fluid. The pyronometer is placed in front of the west section of the direct gain fenestration to monitor the total south-facing vertical radiation inside the cell. The location of this pyronometer is indicated in figure 39.

The location of other sensors is schematically shown in figures 33 to 39 . Figure 33 shows the location of 6 heat flux meters and $19 \mathrm{TC}^{\prime} \mathrm{s}$ placed on the east wall. Figure 34 shows the location of 13 TC's placed on the inside surface of the west wall of cell \#4. Figure 35 shows the location of various sensors placed on the ceiling ( $1 Q$ and $13 \mathrm{TC}$ ) and floor (2Q's and 14 TC's). Figure 36 shows the details of the placement of 46 ground themocouples, and figure 37 shows the location of the foundation probes and the location foundation thermocouples. Figure 38 shows the position of various sensors ( 2 heat flux meters and $18 \mathrm{TC}^{\prime} \mathrm{s}$ ) on the north wall in cell \#4. Figure 39 shows the position of 25 (22 shielded and 3 unshielded) thermocouples used for monitoring the cell air temperature. Figure 39 also shows the location of five black globes and two pink globes used for monitoring the globe temperature. Thermocouple T265, used for monitoring the heater discharge temperature, is not shown in any figure. 


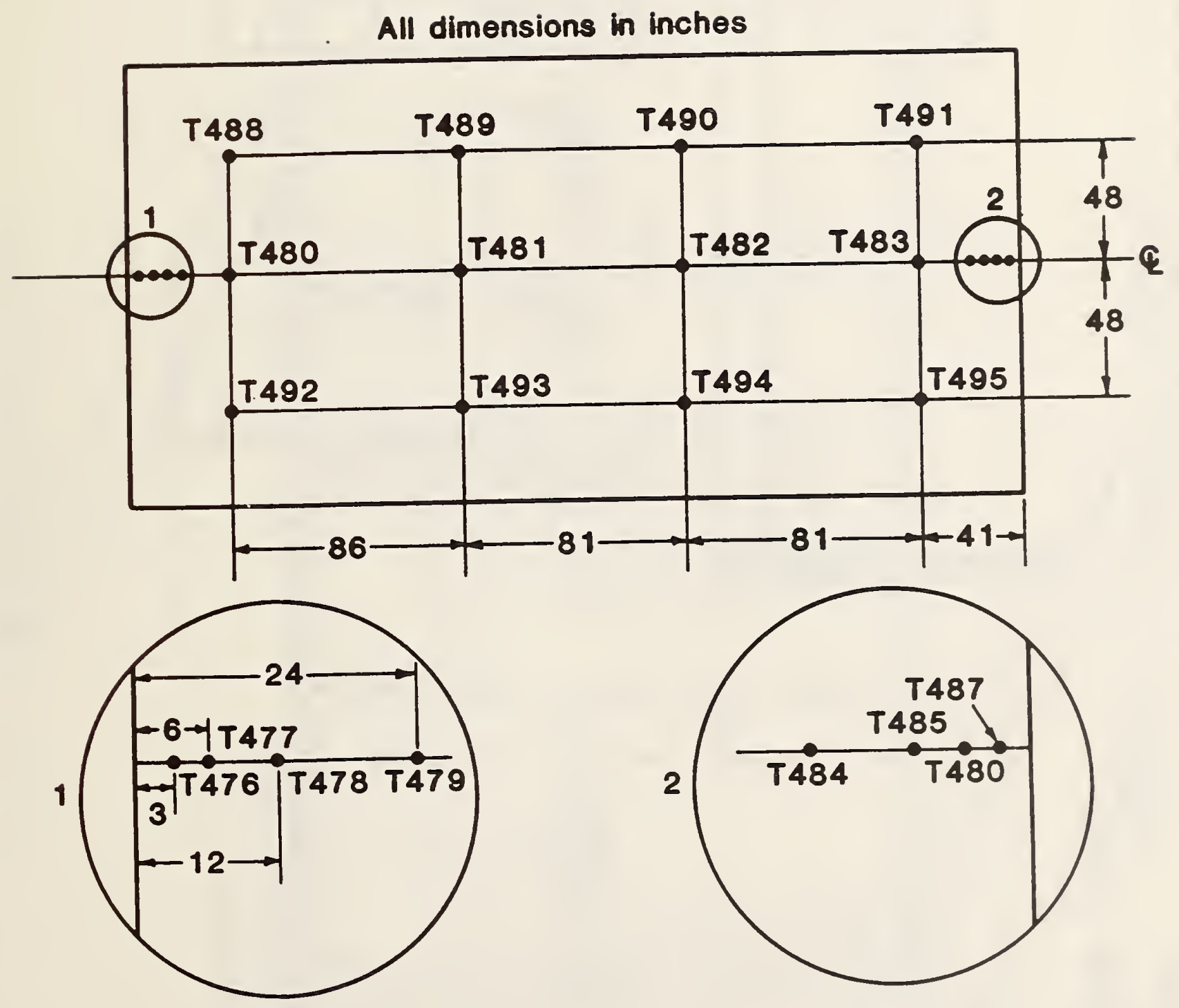

Figure 32. Sensor Locations Floor Surface Cell 非 


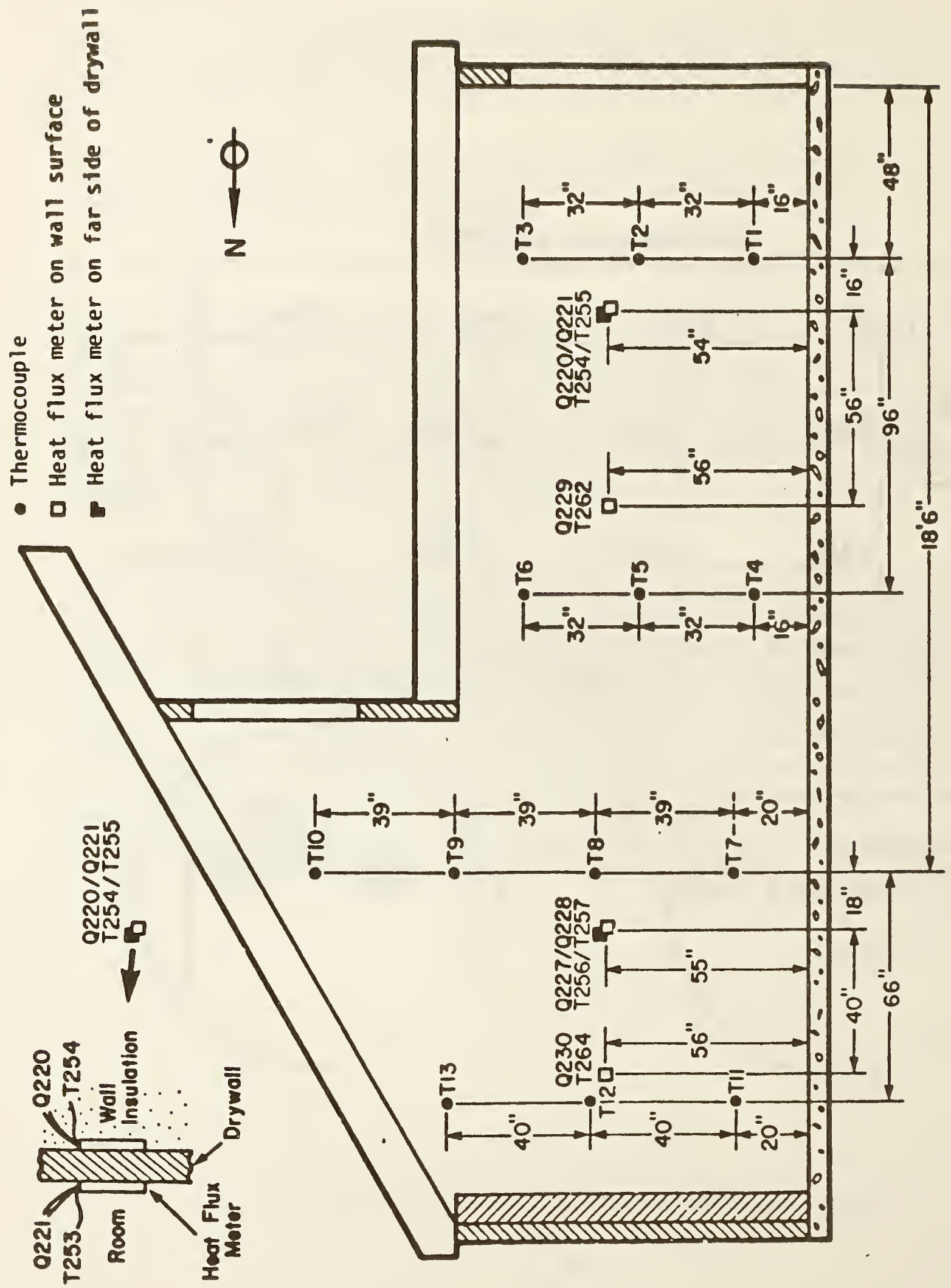

ב 


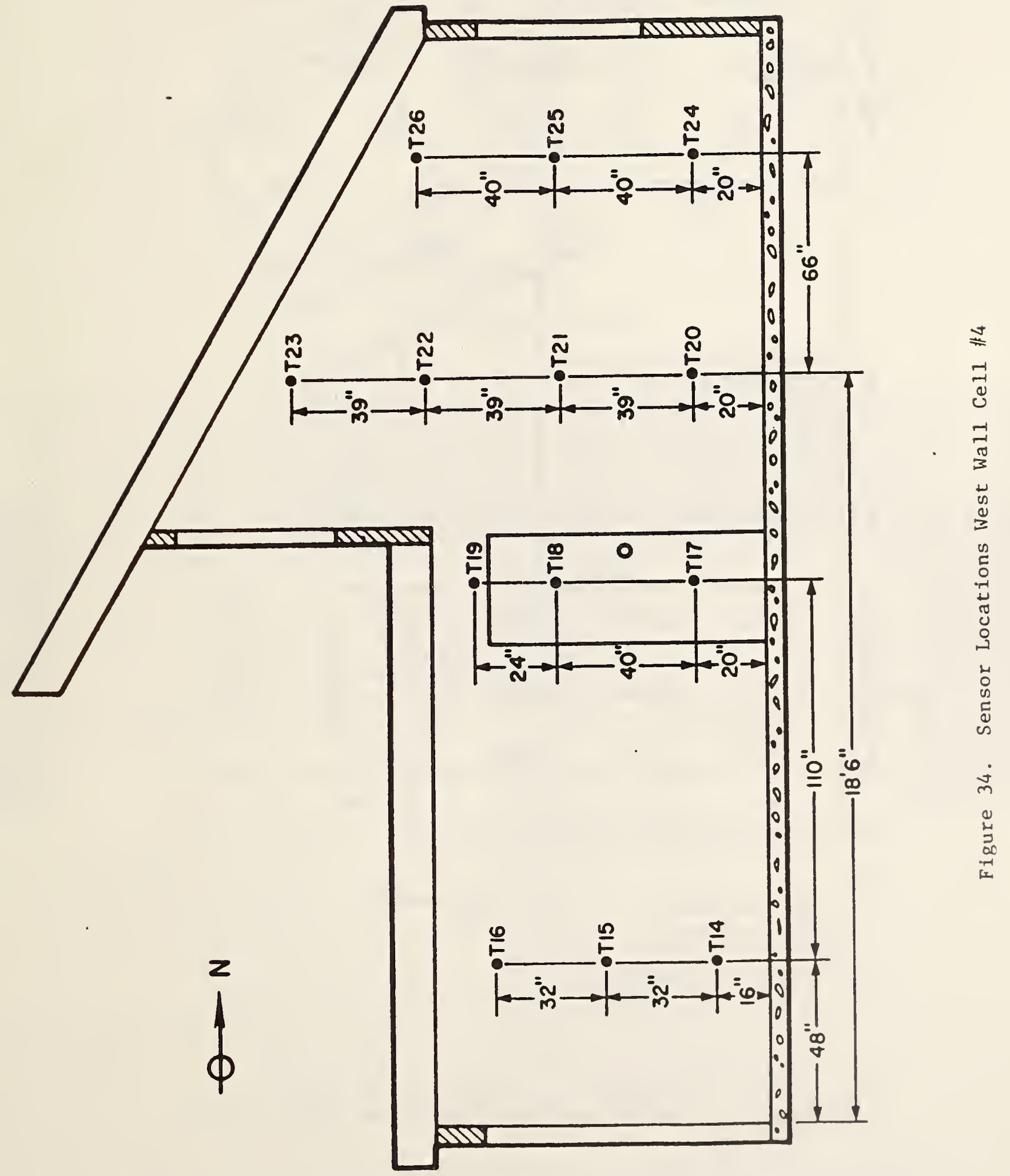




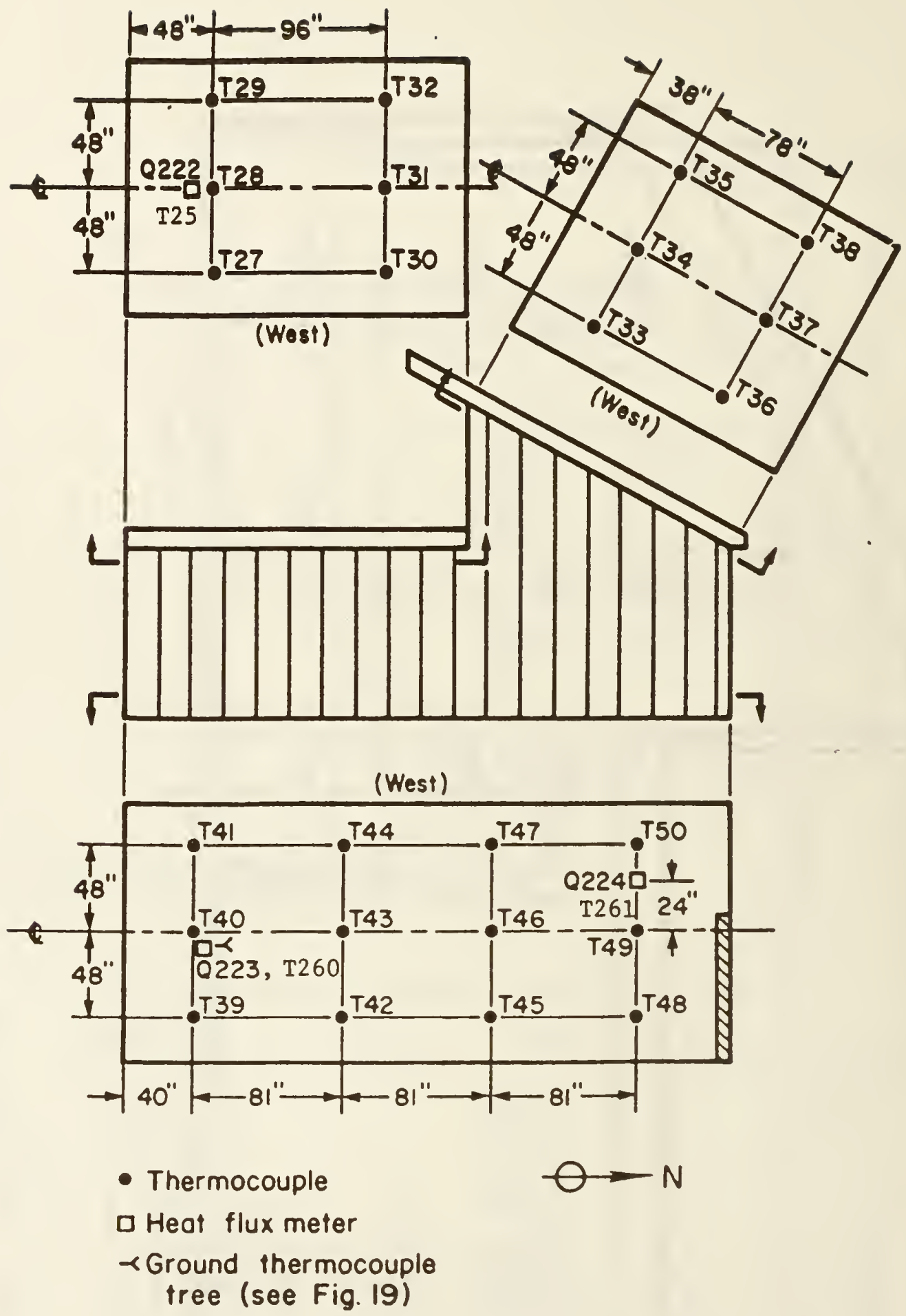

Figure 35. Sensor Locations Ceiling and Floor Cell 非 

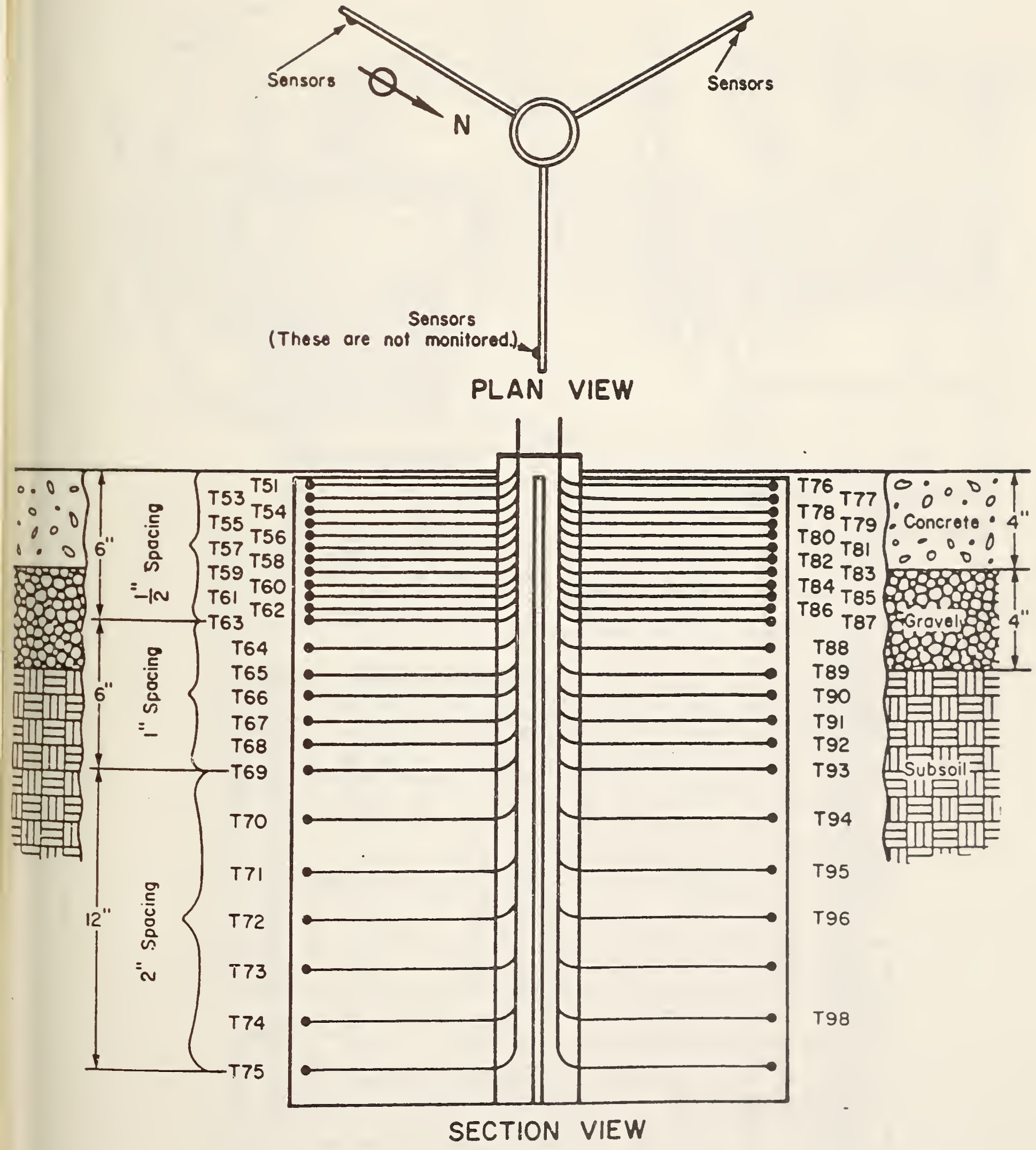

Figure 36. Ground Thermocouple Tree

(See Figure 21 for Location Within Cel1 $\mid / 4$ ) 


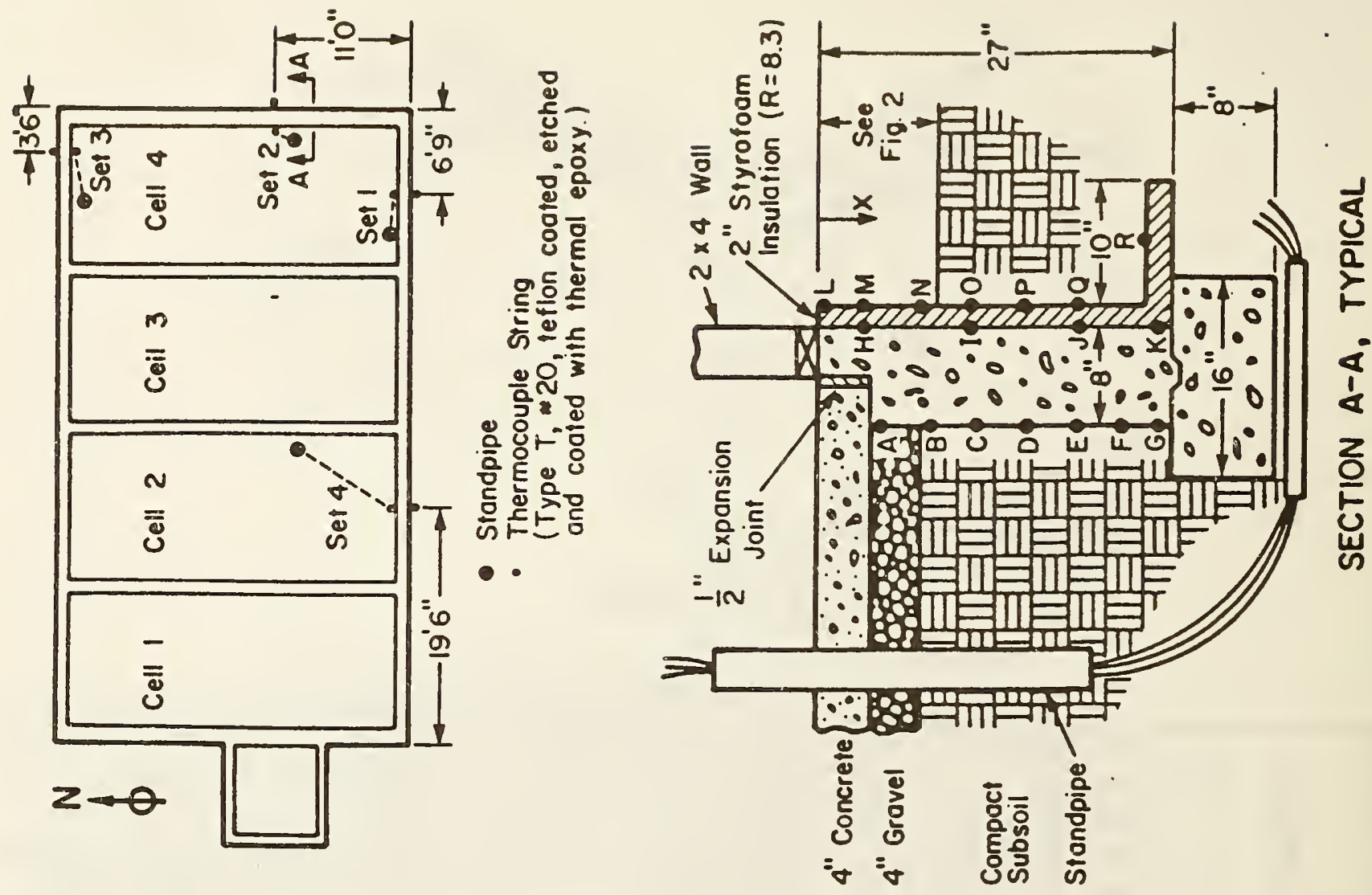

\begin{tabular}{|c|c|c|c|c|c|c|c|c|c|c|c|c|c|c|c|c|c|c|c|}
\hline \multirow{3}{*}{ ڤ } & \begin{tabular}{|l|}
8 \\
8 \\
$\$$ \\
8
\end{tabular} & & & & & & & & & & & & & & & & & & \\
\hline & $\begin{array}{l}. \subseteq \\
x\end{array}$ & $\not x^{2}$ & $\stackrel{\alpha \sigma}{n}$ & $\frac{m 5}{E}$ & $\underbrace{-1}$ & 卣 & 兄 & $\hat{\sim}$ & $\sigma$ & $\stackrel{-N}{\sim}$ & 오 & $\widehat{\sim}$ & $\omega^{N}$ & + & $\infty$ & $\cong$ & 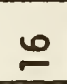 & ㅇ & d \\
\hline & \begin{tabular}{|l|}
$E$ \\
U \\
$x$
\end{tabular} & $\begin{array}{l}\mp \\
\approx\end{array}$ & $\tilde{\sigma}$ & $\begin{array}{l}\infty \\
\dot{N}\end{array}$ & \% & $\underset{\sigma}{\circ}$ & $\begin{array}{l}0 \\
\dot{0}\end{array}$ & $\begin{array}{l}0 \\
\infty \\
0\end{array}$ & $\stackrel{0}{0}$ & $\frac{\infty}{\infty}$ & $\begin{array}{l}\infty \\
0 \\
0\end{array}$ & $\begin{array}{l}0 \\
0 \\
0\end{array}$ & $\stackrel{m}{-}$ & $\stackrel{0}{0}$ & ?ं & in & $\dot{q}$ & $\begin{array}{l}\infty \\
\dot{0}\end{array}$ & $\begin{array}{l}0 \\
\overline{0}\end{array}$ \\
\hline & 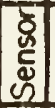 & $\stackrel{\tilde{m}}{E}$ & 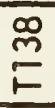 & F & $\stackrel{0}{ \pm}$ & $\Xi$ & $\underset{\mathbb{Z}}{\mathscr{E}}$ & $\underset{\stackrel{m}{E}}{E}$ & $\underset{F}{\stackrel{g}{E}}$ & $\stackrel{\stackrel{2}{5}}{E}$ & $\underset{\stackrel{0}{+}}{F}$ & $\underset{F}{\check{F}}$ & $\begin{array}{l}\infty \\
\underset{\leftarrow}{\leftarrow}\end{array}$ & $\begin{array}{l}\text { g } \\
\stackrel{5}{5}\end{array}$ & 吕 & 巨ే & 㫛 & $\stackrel{m}{\tilde{E}}$ & 泀 \\
\hline & $\begin{array}{l}. \\
x\end{array}$ & n & $\infty$ & $\stackrel{\mathbb{N}}{\stackrel{N}{ }}$ & 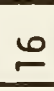 & $\sigma^{-1}$ & $\stackrel{\text { mld }}{\sim}$ & $\underset{\tilde{N}}{\stackrel{i n}{N}}$ & $\nabla$ & $\simeq$ & 온 & $\stackrel{d N}{N}$ & $\alpha^{N}$ & $\theta$ & $\infty$ & $\approx$ & $\stackrel{0}{\circ}$ & 옹 & $\stackrel{\sim}{\sim}$ \\
\hline & $\begin{array}{c}5 \\
\\
\times\end{array}$ & $\stackrel{\sim}{\sim}$ & i & $\underset{\sim}{\sim}$ & ○ & $\begin{array}{l}\text { ? } \\
\text { g }\end{array}$ & m & $\begin{array}{l}\text { ? } \\
\text { g. }\end{array}$ & $\underset{0}{0}$ & ? & $\begin{array}{l}\infty \\
0 \\
0\end{array}$ & テ & m & $\stackrel{\sim}{\circ}$ & ? & ? & $\begin{array}{l}0 \\
0\end{array}$ & $\begin{array}{l}\infty \\
0 \\
0\end{array}$ & $\begin{array}{l}0 \\
6\end{array}$ \\
\hline & 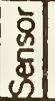 & 吕 & $\underset{ }{\stackrel{ }{ }}$ & $\underset{\varpi}{\check{E}}$ & $\underset{\approx}{\approx}$ & $\underset{\sim}{\stackrel{M}{F}}$ & $\underset{\Xi}{\stackrel{\Xi}{上}}$ & $\stackrel{\stackrel{N}{E}}{\leftarrow}$ & $\underset{\sim}{\stackrel{0}{\sim}}$ & $\underset{\approx}{\approx}$ & $\underset{\sim}{\stackrel{\infty}{\sim}}$ & $\stackrel{\text { I }}{\underset{上}{E}}$ & $\begin{array}{l}\stackrel{p}{E} \\
F\end{array}$ & $\bar{m}$ & $\stackrel{\sim}{F}$ & $\stackrel{m}{\stackrel{m}{F}}$ & $\stackrel{\text { m }}{E}$ & $\stackrel{\stackrel{m}{F}}{F}$ & $\stackrel{e}{E}$ \\
\hline & \begin{tabular}{l|}
. \\
$\times$ \\
\end{tabular} & $\partial^{n}$ & $-\infty 0$ & $\stackrel{\sim}{\stackrel{N}{N}}$ & $\stackrel{6}{6}$ & D̊ & $\stackrel{\text { m }}{\sim}$ & $\approx$ & + & $\stackrel{10}{=}$ & बूँ & $\lesssim$ & $\alpha^{N}$ & $\nabla$ & $\infty$ & $\simeq$ & $\stackrel{0}{-}$ & 오 & $\stackrel{\sim}{\sim}$ \\
\hline & $\begin{array}{l}E \\
\\
\times\end{array}$ & $\stackrel{+}{\doteq}$ & $\begin{array}{l}0 \\
\bar{\sim}\end{array}$ & 品 & $\stackrel{m}{\ddot{\sigma}}$ & กี & m & $\begin{array}{l}0 \\
\infty \\
0 \\
0\end{array}$ & $\stackrel{0}{0}$ & $\begin{array}{l}\infty \\
\stackrel{\sim}{\infty}\end{array}$ & : & $\begin{array}{l}0 \\
\infty \\
0\end{array}$ & $\stackrel{m}{-}$ & $\stackrel{0}{0}$ & $\stackrel{m}{m}$ & ? & $\begin{array}{l}0 \\
0\end{array}$ & $\begin{array}{l}\infty \\
0 \\
0\end{array}$ & $\begin{array}{l}0 \\
\overline{0}\end{array}$ \\
\hline \multirow{4}{*}{$\begin{array}{l}\overline{0} \\
\bar{D}\end{array}$} & 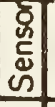 & 음 & 음 & $\stackrel{m}{\mathscr{0}}$ & $\stackrel{\Xi}{\Xi}$ & 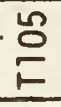 & $\frac{8}{1}$ & 음 & $\begin{array}{l}\text { O } \\
\text { 든 }\end{array}$ & $\stackrel{9}{\circ}$ & & 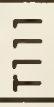 & 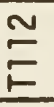 & $\stackrel{m}{E}$ & E & $\stackrel{n}{E}$ & $\stackrel{\omega}{E}$ & E & $\stackrel{\infty}{E}$ \\
\hline & $\frac{5}{x}$ & $\ddot{\sigma}$ & $\vec{\sim}$ & $\simeq$ & $\underline{6}$ & 오 & $\stackrel{\mathcal{D}^{N}}{\sim}$ & $\stackrel{\sim 00}{\sim}$ & n & $\simeq$ & 오 & $\stackrel{-10}{\sim}$ & $\alpha x^{N}$ & $\nabla$ & $\infty$ & $\simeq$ & 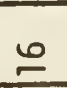 & ㅇ & $\stackrel{\sim}{\sim}$ \\
\hline & $\begin{array}{l}E \\
\dot{U} \\
\times\end{array}$ & $\stackrel{\infty}{\circ}$ & $\stackrel{\circ}{\circ}$ & ? & $\stackrel{m}{\dot{\sigma}}$ & $\begin{array}{l}\infty \\
0 \\
0\end{array}$ & $\underset{\tilde{\sigma}}{\sim}$ & ? & $\stackrel{\sim}{\sim}$ & ? & & o & m & $\stackrel{0}{0}$ & m. & ? & $\dot{0}$ & $\begin{array}{l}\infty \\
0 \\
0\end{array}$ & $\begin{array}{l}0 \\
\overline{6}\end{array}$ \\
\hline & & $<$ & $\infty$ & v & 0 & $\omega$ & $u$ & 0 & $I$ & - & 3 & $x$ & - & $\Sigma$ & $z$ & 0 & a & 0 & $\simeq$ \\
\hline
\end{tabular}


- Thermocouple (on inside block surface)

$\square$ Heat flux meter

$\checkmark$ Thermocouples spaced in mortar (T164-T170)

\begin{tabular}{|l|r|r|r|r|r|r|r|}
\hline Depth from inside surface cm & 0.32 & 2.22 & 6.03 & 9.84 & 13.65 & 17.46 & 19.05 \\
& 0.13 & 0.88 & 2.38 & 3.88 & 5.38 & 6.88 & 7.50 \\
\hline Sensor Number & $T 164$ & $T 165$ & $T 166$ & $T 167$ & $T 168$ & $T 169$ & $T 170$ \\
\hline
\end{tabular}

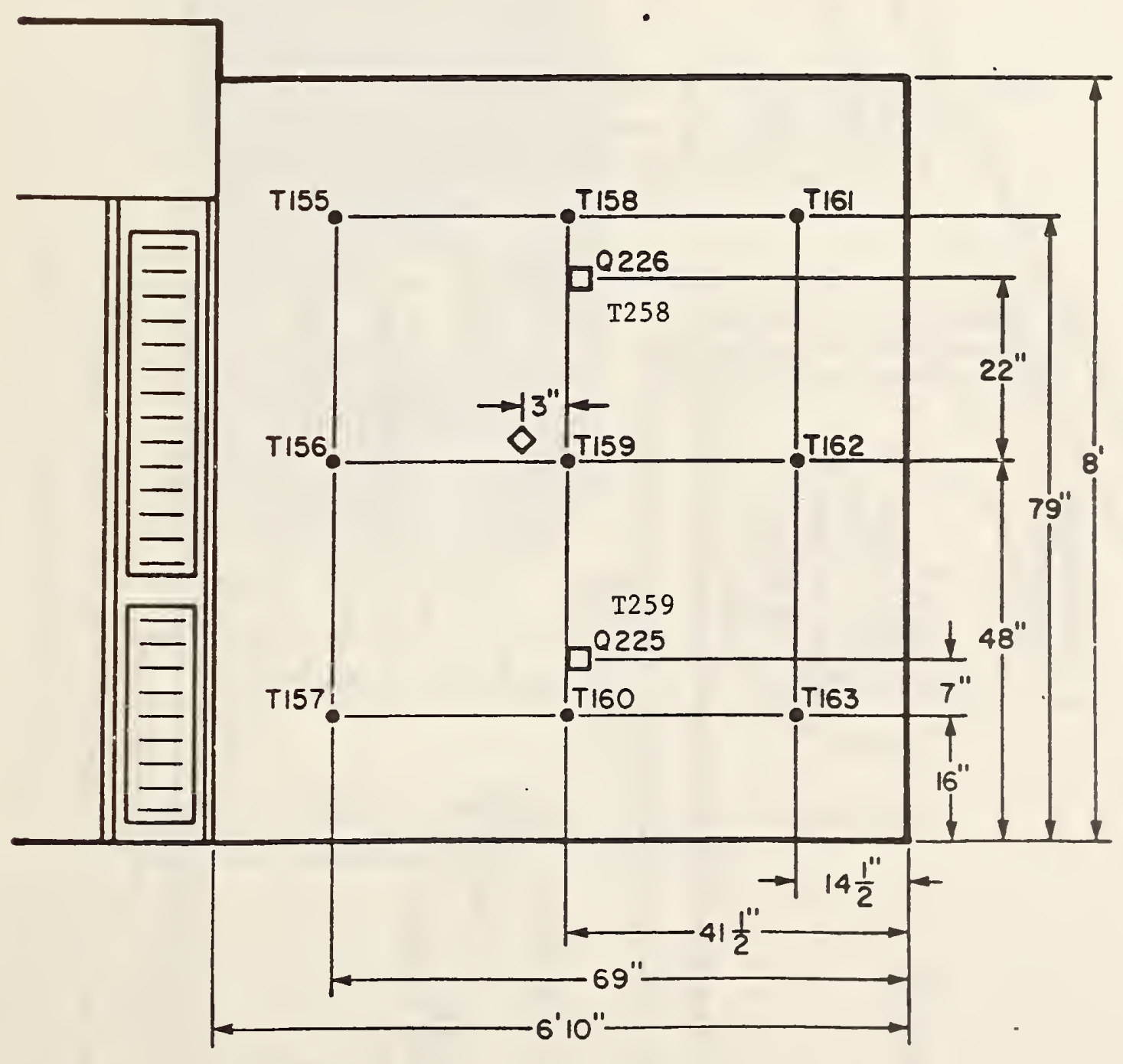

Figure 38. Thermal Storage Wall Sensor Locations in Cell \#4 


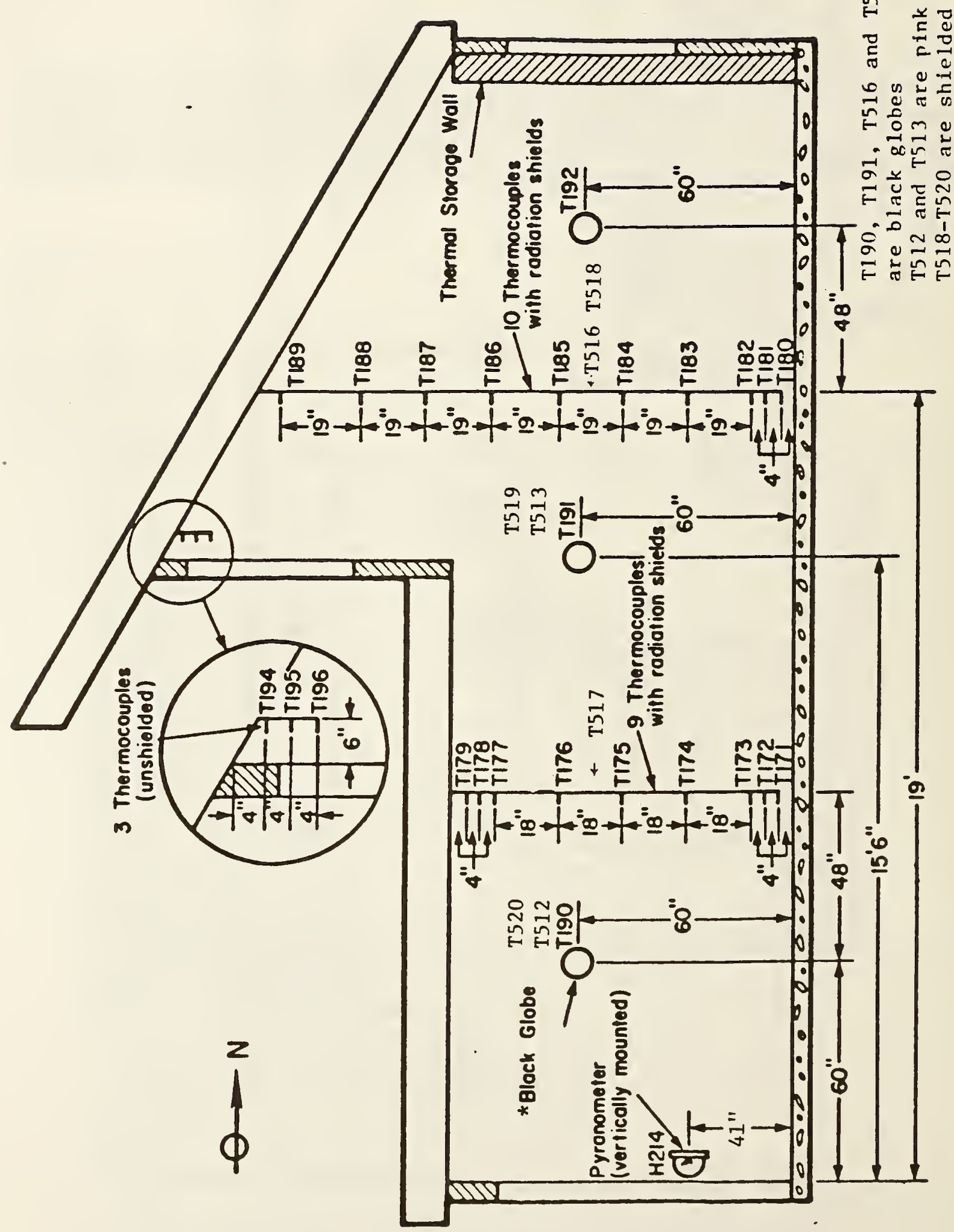

J 


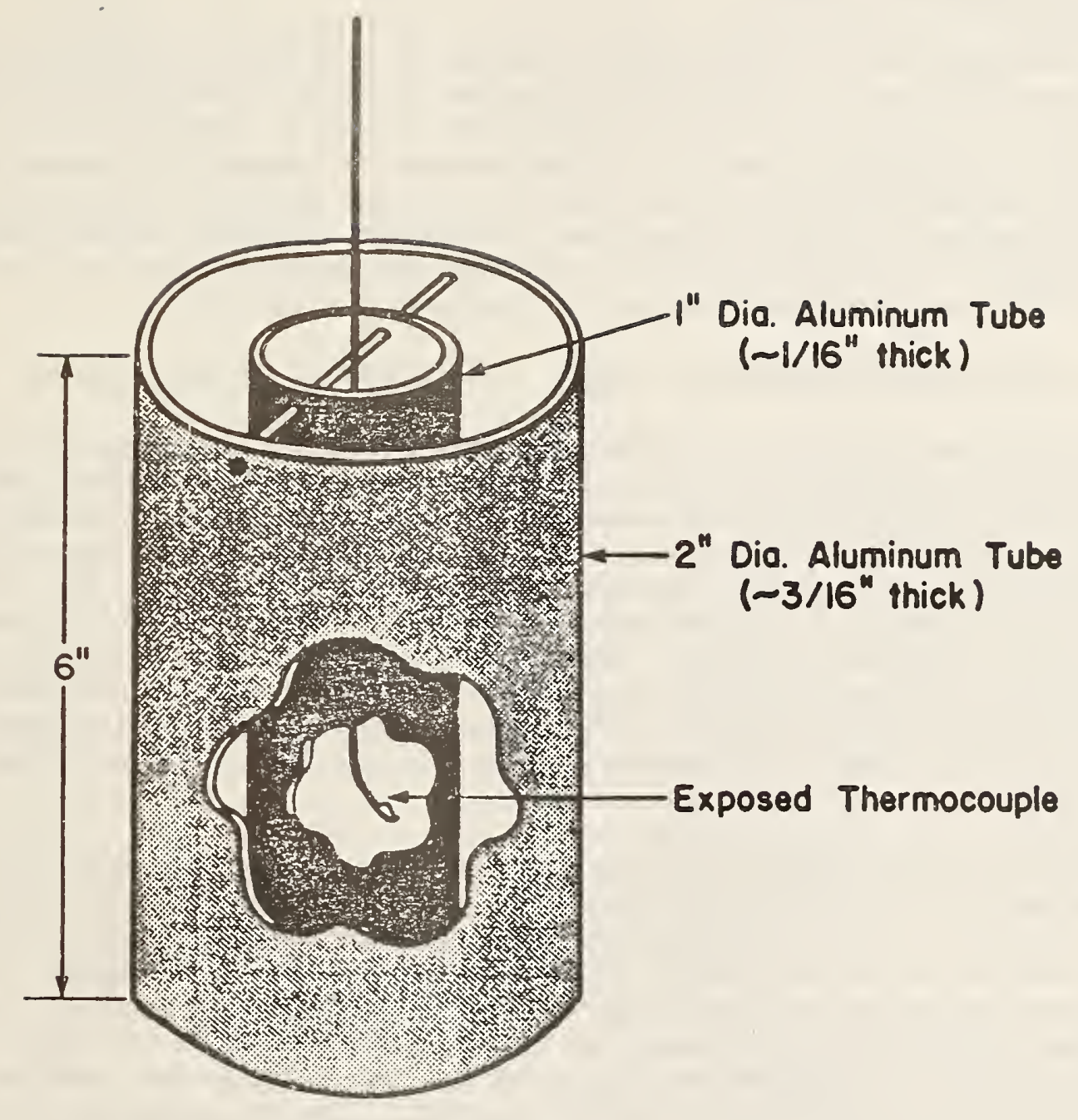

Figure 40. Radiation Shields Used for Thermocouples Measuring Air Temperatures 


\section{DATA ACQUISITION}

\subsection{DATA ACQUISITION SYSTEM}

The new data acquisition system (DAS) consists of a desktop computer with 575K bytes of memory, a real time clock, and a scanner with an integrating digital voltmeter having one microvolt resolution. This system provides greater capacity and improved reliability than the original system. Currently, the DAS is capable of handling about 500 data channels and its capacity can be expanded to handle 700 channels. The system has two cassette drives, and a 9-track, 1600 BPI magnetic tape drive for data and software storage. The DAS was received in March 1983, and its installation was completed in May 1983.

\subsection{AIR INFILTRATION MONITORING SYSTEM}

The multi-zone automated air infiltration monitoring system using the tracer gas decay method was designed and built by $\mathrm{Dr}$. Richard Grot of NBS. The system consists of: a S-100 bus microcomputer with two 8-inch floppy disc drives; a real time clock; a CRT terminal; an electron capture gas chromatograph detector which measures the sulfur hexafluoride $\left(\mathrm{SF}_{6}\right)$ tracer gas in parts per billion range with an accuracy of 2.5 percent; a ten port sample manifold; a group of five tracer gas injection units; a bank of ten auxiliary sample pumps; input data terminals for the wind speed and direction and the ambient and indoor zone temperatures; and the associated software which monitor and control the operation of the system. A detailed description of the system is contained in reference [8].

The tracer gas decay method was used: it consists of a single injection followed by the measuring of the concentration decay of the tracer gas over a three-hour period. The amount of tracer gas injection through each of the five injection units is determined and controlled independently by the microcomputer on the basis of the concentration decay history of the individual injection zones. Ten sampling locations can be selected within a maximum of five zones. A small amount of the air drawn by the auxiliary sample pumps from the ten locations is fed to the gas chromatograph-detector sequentially for measuring of the tracer gas concentration at the ten locations. Extra-pure argon gas (Ar) is used to flush out the detector system between samples. A one-minute time interval is required for measuring each of the sample concentrations and flushing the detector system after the measurement, resulting in a sampling interval of ten minutes for all ten sampling ports. Therefore, five concentration data points per hour for each of the sampling locations are obtained (the last ten-minute interval is reserved for writing data onto the floppy disc, and injection of tracer gas if necessary). These five data points are used to determine the air infiltration rate in terms of air changes per hour on the basis of tracer decay theory and the least-square technique. Since all the ten-minute concentration data are stored on the floppy disc, more accurate least-square analysis based on 15 data points over a three-hour interval (between injections of tracer gas) can also be performed later if necessary. At present, insufficient data exist for purposes of precision and accuracy determination. A reasonable estimate of the uncertainty in a given air change rate determination is of the order of 10 percent or less [9]. 
lior the present passlve solar test house, only three of the five injection units anc nine of the ten sampling ports are used. An injection unit with three sampling ports serves each cell. In each cell the injection port is locaied at the outlet of the far-coil unit with the fan running continuously to obtain a uniform mixing of the injected tracer gas within the test cell. The three sampling ports within each cell are located at the south, center, and north side of the cell midway between the floor and the ceiling at each location. For the first series of experiments the doors between the cells are kept closed and any opening through the walls between the cells is sealed to prevent air novement between the cells. Infiltration data for each sampling location are computed individually on an hourly basis and the averaged value of the three locations is computed to be the infiltration data for the test cell.

\subsection{DATA ACQUISITION AND DISTRIBUTION}

With the exception of air infiltration data which is on a separate system, all dats are taken by the new data acquisition system and stored on the magnetic tape. The solar radiation and weather data are taken at one-minute intervals, watt-hour data are taken at one-hour inervals, and all other data are taken at ten-minute intervals. These data are later numerically integrated and averaged to create hourly average data sets. The hourly average data sets including hourly air infiltration data are recorded onto a magnetic tape in a prior agreed format. A documentation file containing the test conditions and an index to the data records is also recorded onto the magnetic tape. A printout of the "Data Documentation" is given in Appendix A as an example. The data tape along with a printout of the documentation is distributed to the participant researchers for their use. The hourly average data sets are also archived at the National Bureau of Standards from where they are available upon request.

\subsection{ESTIMATES OF UNCERTAINTY IN THE MEASURED DATA}

Some of the factors that contribute to the uncertainty in the measured data include type of measurement or data, type of sensor used and the material of its construction, application environment and sensor mounting techniques, data scanning and logging equipment, and conversion from electrical signals of sensors to englneering quantities. Estimates of measurement uncertainty for various types of data taken at the NBS test facility are given in table 6 , and are discussed below: 
Table 4. Estimates of Measurement Uncertainty for Different Data

\begin{tabular}{|c|c|c|}
\hline $\begin{array}{c}\text { Item } \\
\#\end{array}$ & Data Type & EstImated Measurement Uncertainty \\
\hline $\begin{array}{l}1 \\
2 \\
3 \\
4 \\
5 \\
6\end{array}$ & $\begin{array}{l}\text { Alr infiltration } \\
\text { Auxillary energy } \\
\text { Heat flux } \\
\text { Solar radiation } \\
\text { Temperature } \\
\text { Wind speed } \\
\text { Wind direction }\end{array}$ & $\begin{array}{l} \pm 10 \% \\
<0.1 \% \\
\text { current } 1 \mathrm{y} \text { indeterminate } \\
\pm 5.0 \% \\
\pm 0.5^{\circ} \mathrm{C} \\
\pm 2.0 \% \text { with threshold } 0.58 \mathrm{~m} / \mathrm{s} \\
\pm 3 \text { degrees }\end{array}$ \\
\hline
\end{tabular}

\section{Air Infiltration}

It was discussed earlier in the previous section that at the present state-ofthe-art the existing data are insufficient for the purposes of precision and uncertainty determination. A reasonable estimate of uncertainty in a given aix change rate, measured by the tracer gas decay method, is about \pm 10 percent [9].

\section{Auxiliary Energy Supply}

The auxiliary energy supplied to the three test cells via six watt-hour meters is measured by a six pulse counter with the minimum interval equal to 1.8 watthours. Therefore, regardless of the measurement interval the maximum uncertainty of \pm 1.8 watt-hour is expected in a given measurement. The long term uncertainty in the energy supply measurement is estimated to be less than \pm 0.1 percent by repeated comparison of measured data with commerclal watt-hour meter readings.

\section{Heat Flux}

The heat-flux meter used in the direct gain cell (i.e., cell 非) of the NBS test facility were calibrated in a sandwich mode using the "guarded hot-plate" facility at NBS. However, a definitive estimate of uncertainty in the measured heat flux data cannot be made at present.

The measurement of heat flux with heat flow sensor (heat-flux meter) was the subject of a two-day workshop sponsored by the American Society for Testing and Materials (ASTM). The author attended the ASTM Workshop on Building Application of Heat Flow Sensors held at the ASTM headquarters in Philadelphia, PA, on September 22-23, 1983. The general opinion of the experts in the field is that the measurements of heat flow with heat-flux meters are not very reliable, particularly if the meter's application condition are not similar to the meter's calibration condition. Also, presently the techniques or the procedures for calibrating a heat-flux meter are not standarized. 
Some of the factors which contribute to uncertainty of heat flow measurement include: (1) thermal and radiometeric properties of the meter material with respect to those of the test structure material; (2) contact resistance due to contact between the meter and test article; (3) convection around the meter; (4) multidimensional conduction; (5) thermal inertia of meter with respect to that of the test structure; and (6) instability of heat field or unsteady nature of heat transfer process [10]. More experimental research is needed to quantify the effects of the abovementioned factors on the heat flow data measured by heat-flux meters.

\section{Solar Radiation}

Solar radiometry is an inexact science with international comparisons showing disagreement of as much as 7 percent [11]. The sensitivity of Normal Incident Pyrheliometers (NIP's) is in general shown to be within 0.5 percent of absolute cavity radiometers that defines the World's Radiometric Reference Scale [12,13]. The NIP used at the test facility has been calibrated within the year and intercompared within 1 percent to other NIPs. Since the NIP readings are sensitive to the alignment, the tracer of the NIP is realigned twice a day for the duration of each tests at the NBS test facility.

A sensitivity intercomparison of four side-by-side PSP pyronometers showed an agreement of within 1 percent [14]. In this intercomparison the temperature correction was not made and cosine response was not determined. Instantaneous values may be uncertain by as much as 3 percent depending on conditions. The instruments used at the NBS test facility are by one manufacturer and are periodically recalibrated by the supplier. Also, these instruments have been periodically intercompared at the test facility and the data agreed within 1 percent. Some uncertainty in the pyronometer data may also arise due to misalignment of the instrument. A conservative estimate of overall uncertainty in the solar radiation data is \pm 5 percent.

\section{Temperatures}

The thermocouples at the NBS test facility were installed by following the "procedures for minimizing error" described in the ASTM Special Technical Publication, ASTM SPT-470 [15]. Some of the thermocouples, before their installation were calibrated in standard ice and hot water baths by following the procedures described in the ASTM Standard E-220-80 [14]. These thermocouples were calibrated over the temperature range of 0.0 to $60^{\circ} \mathrm{C}$, and thermocouple data were within $\pm 0.2^{\circ} \mathrm{C}$ of the reading of the standard thermometer. The voltage data from thermocouples are converted to temperatures in degree Celsius $\left({ }^{\circ} \mathrm{C}\right)$ by using the quadratic expansion equation and the values of expansion coefficients given in reference 17. The uncertainty due to long leads of the thermocouples is considered to be negligible. Additional unknown uncertaintles due to inhomogeneity and change in material properties is anticipated.

The thermocouples used for measuring the room air temperature in cells 2 and $\#_{4} 4$ are provided with double radiation shields (see figure 40). The effectiveness of the sheilds were tested at NBS as: the data from shielded thermocouples were compared with data from mechanically aspirated and shielded 
thermocouples the readings were within $\pm 0.1^{\circ}$ of each other. An estimate of the maximum overall uncertainty in the thermocouples data, including errors due to reference, multiplexing, and conversion, is $\pm 0.5^{\circ} \mathrm{C}$.

\section{Wind Speed and Direction}

The anemometer and vane used for measuring the wind speed is factory calibrated and has a claimed uncertainty of \pm 2 percent with a threshold of $0.58 \mathrm{~m} / \mathrm{s}$; and wind direction is \pm 3 degrees.

\section{Data Scanner}

For verifying the resolution of the digital voltmeter of the data scanner and for assuring that the DAS is functioning properly, the DAS is provided with one reference, one millivolt signal, and five reference zero volt signals. The zero volt signals are produced by electrically shorting a data channel on a multiplexing card. The reference signals are placed on five different strategically selected multiplexing cards. The one millivolt reference channel and one of the reference zero volt channel are scanned at one-minute intervals, and all of the six reference voltage channels are scanned at ten-minute intervals. The one-minute interval data are only displayed on the CRT (screen), while the ten-minute interval data from these reference channels in addition to being displaced on the CRT is also recorded on the magnet1c tape along with other data. The data taken to-date has assured us that the system had been functioning properly during the experiments, and has also verified the acclaimed 1 microvolt resolution of the voltmeter. 


\section{CONCLUDING REMARKS}

As a part of the DoE's Experimental Systems Research Program, the NBS Passive Solar Test facility has been constructed in Gaithersburg, Maryland. The test facility is used to collect class A level performance monitoring data for different passive solar system under different experimental conditions. The data is distributed to various researchers for use in: (1) detailed building energy analysis and models/algorithms validation; and (2) performance characterization of passive solar systems. This handbook provides, for the users of these data (i.e., models/algorithms developers/validators), a complete physical description of the test building, sensor locations, data acquisition procedures, and an estimate of uncertainty in the measured data.

The following items are available from the Natfonal Bureau of Standards: (1) This handbook; (2) data documentation (see appendix); and (3) magnetic tapes containing hourly average sets of data collected at the NBS test facility. Additional information concerning the NBS Passive Solar Test Facility and Experimental Data may be obtained from:

Bal Mahajan

Building Equipment Group/Building Equipment Division

Center for Building Technology

National Bureau of Standards/Building 226/ Room B306

Washington, D.C. 20234

Phone (301) -921-3294

\section{ACKNOWLEDGEMENT}

This work is sponsored by the Passive and Hybrid Solar Division, Office of Solar Heat Technologies, U.S. Department of Energy, Washington, DC 20585, as part of the experimental system research program.

The author wishes to express his sincere gratitude to Dr. Kent A. Reed and Dr. Stanley T. Liu for their many valuable suggestions. 


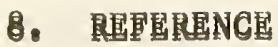

1. "Program Area Plan: Performance Evaluation of Paedve/Hybrid solar Heating and Cooling Syotem," Solar Energy Research Institute Report SERI/PK-721-788, October 1980, Golden, CO.

2. Hamilton, B. L. and Scofleld, P. M., "Nat1onal Passive/Hybrid Performance Evaluation Program for System Development," Proceedings of the 5th National Passive Solar Conference, Amherst, MA, October 1980.

3. Lindler, Ke1th W., "National Bureau of Standards Passive Solar Test Building Handbook," NBS-GCK-82-398, August 1982, Nat1onal Bureau of Standards Washington, DC 20234.

4. Mahajan, Bal M. and Liu, Stanley T., "Initlal Results from the NBS Passive Soler Test Facility," Proceedings of the ASME Solar Division Sixth Annual Technical Conference, Apr11 19-21, 1983

5. Mahajan, Bal M. and Liu Stanley T., "Results from the NBS Passive Test Facility - A Status Report," Proceedings of the Passive and Hybrid Solar Energy Update, September 26-28, 1983.

6. McCabe, M. E., Bushby, S., and Ducas, W., "Conceptual Des1gn and Performance Specification for the Passive Solar Component Calorimeter," NBS Letter Report to DoE, March 1982.

7. "Natlonal Bureau of Standards Direct-Gain Test Cell Site Handbook," Los Alamos National Laboratory Report No. LA-9786-MS, edited by Nancy Sheheen, Q Division, 1983.

8. Grot, R. A., Hunt, C. M., and Harrje, D. T., "Automatic Air Infiltration Measurements in Large Bulldings," Proceeding of the First AIC Conference Infiltration and Measuring Techniques; Windsor, U. K., October 8-10, 1980.

9. ASTM Standard E741.80, "Standard Practice for Measuring Air Leakage Rate Using Tracer Dilution Method," ASTM, 1980.

10. Johannesson, Gudni., "Heat Flow Measurements: Thermoelectrical Meters, Function Principles and Sources of Errors," Lund Institute of Technology Report TVBH-3003, Lund, Sweden, 1979. Translated by U.S. Army Corps of Engineering, March 1982.

11. Proceedings of the International Energy Agency Conference on Pyronometer Measurements, Final Report," SERI/TR-642-1156R, March 1981, Solar Energy Research Institute, Boulder, $\mathrm{CO}$.

12. Zerlant, G. A., Bern, J., Maybee, J., and Nooring, W., "The 1981 Intercomparison of Pyronometers and Normal Incldent Beam Pyrhellometers at New RIver, ArIzona, I. Pyrheliometers," DSET Report 81-1218L, December 1981. 
13. Zerlaut, G. A., Bern, J., Maybee, J., and Nooring, W., "The Second New River Intercomparison of Pyronometers and Normal Beam Pyrheliometers," DSET Report 82-0703E, July 1982.

14. Zerlaut, G. A., Bern, J., Maybee, J., and Nooring, W., "The 1981 Intercomparison of Pyronometers and Normal Incident Pyrhellometers at New River, Arizona. II. Pyronometers," DSET Report 82-0104L, January 4, 1982.

15. "Manual on the Use of Thermocouples in Temperature Measurement," ASTM Special Technical Publication, ASTM STP-470, 1980.

16. ASTM, "Calibration of Thermocouples by Comparison," ASTM Standard E228-80; 1980.

17. Powe1, R. L. et a1., "Thermocouples Reference Tables Based on the JPTS68;" NBS Monograph 125, March 1974. 


\section{APPENDIX A}

A copy of the "Data Documentation" distribution to various researchers along with the data tapes. 
DATA DOCUMENTATION.

THE ACCOMPANYING MAGNETIC TAPE CONTAINS DATA COLLECTED AT THE NATIONAL BUREAU OF STANDARDS PASSIVE SOLAR TEST FACILITY DURING TESTS CONDUCTED FROM FEBRUARY 17.1984 TO MARCH 12.1984. CONDITIONS FOR THE TESTS WEIE:

LOWER BOUND TEMPERATURE: FIXED IN ALL CELLS. UPPER BOUND TEMPERATURE: FREE FLOATING IN ALL CELLS. CLERESTORY SHUTTERS: CLOSED IN CELL \$3.\& OPEN IN CELLS $\$ 2 \& \$ 4$. VENTS OF THE TROMBE WALL: BLOCKED IN CELL $\$ 2$. FAN COIL UNIT FAN: ON IN ALL CELLS. ADDITIONAL DESTRATIFYING FANS: ON IN CELL $\$ 4$. THE TAPE'S CONTENTS ARE:

1) DOCUMENTATION FILE (THE MATERIAL YOU ARE READING).

2) $\mathrm{EOF}$

3) DATA FILE FROM 2/17, HOUR 16 TO 3/12. HOUR 16

4) EOF

5) EOF 
THE DATA FILES ARE ARRANGED INTO ROWS AND COLUMS WITH EACH ROW CORRESPONDING TO A LOGICAL RECORD ON THE MAGNETIC TAPE AND EACH COLUMN CORRESPONDING TO AN ENTRY IN THE RECORD. THE FIRST ENTRY IN EACH RECORD IS THE NUMBER OF THE ROW TO WHICH THE RECORD CORRESPONDS. WHILE THE FOLLOWING EIGHT ENTRIES IN THE RECORD REPRESENT THE HOURLY AVERAGE READINGS. EACH SET OF 56 ROWS CONSTITUTES A PHYSICAL BLOCK ON THE MAGNETIC TAPE. EACH PHYSICAL BLOCK CONTAINS A COMPLETE SET OF HOURLY AVERAGE READINGS FOR A GIVEN HOUR, FOR THE SENSORS MONITORED AT THE PASSIVE TEST FACILITY.

THE READINGS FOR THE AVERAGES WERE TAKEN AS FOLLOWS

EVERY HOUR - AUXILIARY ENERGY SUPPLIED AND AIR INFILTRATION. EVERY 1 MINUTE - WIND SPEED AND DIRECTION. AND SOLAR RADIATION. EVERY 10 MINUTES - ALL OTHER READINGS.

THE DATA ARE WRITTEN WITH THE FOLLOWING SPECIFICATIONS

FORMAT................... (I2.8F9.2)

CHARACTER SET...............ASCII

TAPE DENSITY..............1600 BPI

TRACKS...................9

CHARACTERS/RECORD...........80

RECORDS/BLOCK..............56

ALL TIMES REFER TO EASTERN STANDARD TIME. 
AN INDEX TO THE DATA IS GIVEN BELOW.

LOCATION/DESCRIPTION OF EACH SENSOR IS FOLLOWED BY A LABEL.THE LABEL IN THE PARENTHESIS IS SAME AS THE LABEL IN THE SITE HANDBOOR. THE SENSORS ARE LABELED BY A LETTER AND A NUMBER.THE LETTERS INCLUDE H(RADIATION), Q(HEAT FLUX),T(TEMPERATURE), H(WEATHER) , AND WH(WATT-HOUR). ALL TEMPERATURES, UNLESS SPECIFIED OTHERWISE,ARE MEASURED WITH TYPE T THERMOCOUPLES.

HEAT FLUX AND RADIATION DATA ARE GIVEN AS W/ME:2, TEMPERATURES IN DEGREE C. UXILIARY ENERGY IN WATT-HOURS , WIND SPEED IN M/S . AND WIND DIRECTION IN DEGREES. AN ASTERISK INDICATES THAT THE SENSOR WAS INOPERATIVE OR WAS NOT MONITORED, AND A VALUE OF 9999.99 IS GIVEN AS DATA FOR THE SENSOR.

ANY QUESTIONS REGARDING THIS DATA SHOULD BE ADDRESSED TO

BAL M. MAHAJAN / STANLEY T. LIU

BLDG 226 - ROOM B306

CENTER FOR BUILDING TECHNOLOGY

NATIONAL BUREAU OF STANDARDS

WASHINGTON D.C. 20234

PHONE 301-921-3294 OR 301-921-2607 (COMMERCIAL) $921-3294$ OR $921-2607 \quad$ (FTS) 
COLUMN

1 RTD CELL 44 FCU OUT

- 2 RTD CELl 4499 CM Fr SOUth hall 150 CM FR FLOOR

NEAR THERMOSTAT

( $R 236)$

3 E WALL SURF TEMP CELL 4122 CM FROM S WALL 41 CM FRM FLOOR (R237)

E WALL SURF TEMP CELL \$4 122 CM FROM S WALL 122 CM FRM FLOOR

E WALL SURF TEMP CELL \$4 122 CM FROM S WALL 203 CM FRM FLOOR

E WALL SURF TEMP CELL 4366 CM FROM S WALL 41 CM FRM FLOOR

7 E WALL SURF TEMP CELL 4366 CM FROM S WALL 122 CM FRM FLOOR
8 E WALL SURF TEMP CELL $\$ 366$ CM FROM S WALL 203 CM FRM FLOOR

: : : : : : : : : : : : : : : : : : : : : : : : : : : : : : : : : : : : : : : : : : : : : : : : : : : : : : : : : : : : : : : : : : : : : : : : : : :

COLUMN

1 E WALL SURF TEMP CELL $\$ 533$ CM FROM S WALL 51 CM FRM FLOOR

2 E WALL SURF TEMP CELL 4533 CM FROM S WALL 150 CM FRM FLOOR

3 E WALL SURF TEMP CELL 533 CM FROM S WALL 249 CM FRM FLOOR

4 E WALL SURF TEMP CELL 4533 CM FROM S WALL 348 CM FRM FLOOR

5 E WALL SURF TEMP CELL $\$ 4700$ CM FROM S WALL 51 CM FRM FLOOR

6 E WALL SURF TEMP CELL $\$ 700$ CM FROM S WALL 152 CM FRM FLOOR

7 E WALL SURF TEMP CELL $\$ 4700 \mathrm{CM}$ FROM S WALL 254 CM FRM FLOOR

8 W WALL SURF TEMP CELL 4122 CM FROM S WALL 41 CM FRM FLOOR

(T7)

(T8)

(T9)

(T10)

(T11)

( T12)

(T13)

(T14)

: : : : : : : : : : : : : : : : : : : : : : : : : : : : : : : : : : : : : : : : : : : : : : : : : : : : : : : : : : : : : : : : : : : : : : : : : : : : : : : :

COLUMN

1 W WALL SURF TEMP CELL 4122 CM FROM S WALL 122 CM FRM FLOOR

2 W WALL SURF TEMP CELL \$4 122 CM FROM S WALL 203 CM FRM FLOOR

3 W WALL SURF TEMP CELL 4366 CM FROM S WALL 51 CM FRM FLOOR

4 W WALL SURF TEMP CELL 4366 CM FROM S WALL 152 CM FRM FLOOR

5 W WALL SURF TEMP CELL 4366 CM FROM S WALL 203 CM FRM FLOOR

6 W WALL SURF TEMP CELL $\$ 4533$ CM FROM S WALL 51 CM FRM FLOOR

7 W WALL SURF TEMP CELL 4533 CM FROM S WALL 150 CM FRM FLOOR

8 W WALL SURF TEMP CELL 4533 CM FROM S WALL 249 CM FRM FLOOR

( $\mathrm{T}$ 15)

(T 16)

(T17)

(T18)

(T19)

(T20)

(T21)

(T22)

: : : : : : : : : : : : : : : : : : : : : : : : : : : : : : : : : : : : : : : : : : : : : : : : : : : : : : : : : : : : : : : : : : : : : : : : : : : : : : : :

COLUMN

1 W WALL SURF TEMP CELL 4533 CM FROM S WALL 348 CM FRM FLOOR

(T23)

2 W WALL SURF TEMP CELL $\$ 400$ CM FROM S WALL 51 CM FRM FLOOR

3 W WALL SURF TEMP CELL $\$ 4700$ CM FROM S WALL 152 CM FRM FLOOR

(T24)

W WALL SURF TEMP CELL $4700 \mathrm{CM}$ FROM S WALL 254 CM FRM FLOOR

(T25)

4 W WALL SURF TEMP CELL 4700 CM FROM S WALL 254 CM FRM FLOOR
5 CEIL SURF TEMP CELL 4122 CM FRM S WALL 122 CM W OF CENT LN

(T26)

6 CEIL SURF TEMP CELL 4122 CM FRM S WALL ON CENT LN

(T27)

(T28)

7 CEIL SURF TEMP CELL * 122 CM FRM S WALL 122 CM E OF CENT LN

(T29)

8 CEIL SURF TEMP CELL $\$ 4366$ CM FRM S WALL 122 CM W OF CENT LN

(T30)

: : : : : : : : : : : : : : : : : : : : : : : : : : : : : : : : : : : : : : : : : : : : : : : : : : : : : : : : : : : : : : : : : : : : : : : : : : : : : : : :

ROW 9

COLUMN

CEIL SURF TEMP CELL 4366 CM FRM S WALL

ON CENT LN

(T31)

CEIL SURF TEMP CELL 4366 CM FRM S WALL 122 CM E OF CENT LN

3 SLOPED CEIL 97 CM ALONG SURF FR CLRSTY 122 CM W OF CENTER LN

SLOPED CEIL 97 CM ALONG SURF FR CLRSTY ON CENTER LN

(T34)

5 SLOPED CEIL 97 CM ALONG SURF FR CLRSTY 122 CM E OF CENTER LN

SLOPED CEIL 290 CM ALONG SURF FR CLRSTY 122 CM W OF CENTER LN

SLOPED CEIL 290 CM ALONG SURF FR CLRSTY ON CENTER LN

8 SLOPED CEIL 290 CM ALONG SURF FR CLRSTY 122 CM E OF CENTER LN 
ROW 10

COLUMN

1 FLOOR SURF TEMP CELL $\$ 4102$ CM FRM S WALL 122 CM E OF CENT LN

2 FLOOR SURF TEMP CELL 4102 CM FRM S WALL ON CENT LN

3 FLOOR SURF TEMP CELL 4102 CM FRM S WALL 122 CM W OF CENT LN

4 FLOOR SURF TEMP CELL 4307 CM FRM S WALL 122 CM E OF CENT LN

5 FLOOR SURF TEMP CELL \$4 307 CM FRM S WALL ON CENT LN

6 FLOOR SURF TEMP CELL 4307 CM FRM S WALL 122 CM W OF CENT LN

7 FLOOR SURF TEMP CELL $\$ 4513$ CM FRM S WALL 122 CM E OF CENT LN

8 FLOOR SURF TEMP CELL 4513 CM FRM S WALL ON CENT LN

(T39)

(T40)

(T41)

(T42)

(T43)

(T44)

(T45)

(T46)

\section{: : : : : : : : : : : : : : : : : : : : : : : : : : : : : : : : : : : : : : : : : : : : : : : : : : : : : : : : : : : : : : : : : : : : : : : : : : : :}

COLUMN

ROW 11

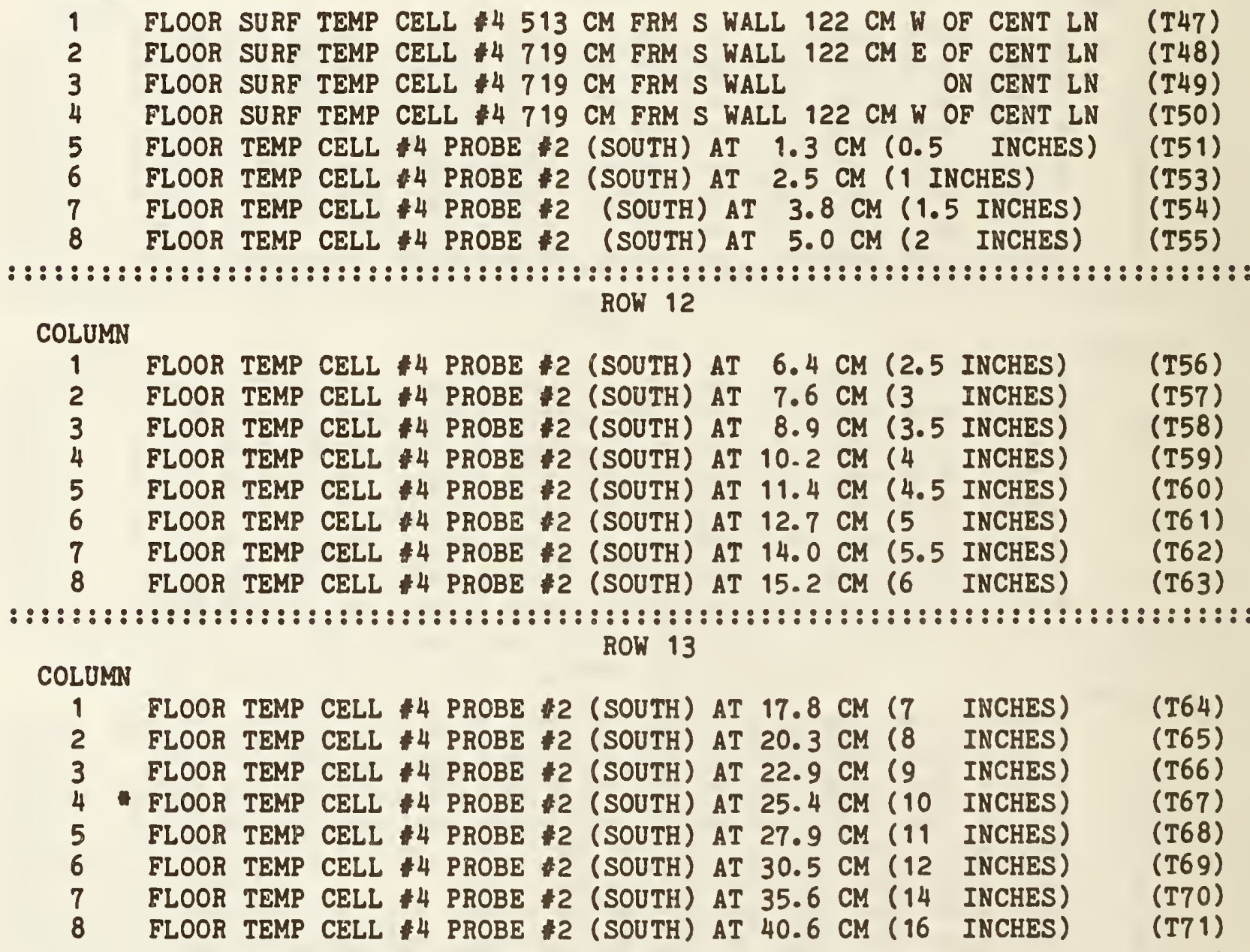

: : : : : : : : : : : : : : : : : : : : : : : : : : : : : : : : : : : : : : : : : : : : : : : : : : : : : : : : : : : : : : : : : : : : : : : : : : : : : : : :

COLUMN

1 FLOOR TEMP CELL 4 PROBE 2

ROW 14

2 FLOOR TEMP CELL $\$ 4$ PROBE $\$ 2$

(SOUTH) AT 45.7 CM ( 18 INCHES)

(T72)

(SOUTH) AT $50.8 \mathrm{CM}(20$ INCHES)

(T73)

FLOOR TEMP CELL 4 PROBE $\$ 2$

(SOUTH) AT 55.9 CM( 22 INCHES)

FLOOR TEMP CELL $\$ 4$ PROBE \#2

(SOUTH) AT 61.0 CM (24 INCHES)

(T75)

FLOOR TEMP CELL $\$ 4$ PROBE $\$ 3$

(NW) AT $1.3 \mathrm{CM}(0.5$ INCHES)

(T76)

- Floor teMP CELL 4 PROBE 3

(NW) AT $2.5 \mathrm{CM}(1$ INCHES)

(T77)

FLOOR TEMP CELL 4 PROBE 3

(NW) AT $3.8 \mathrm{CM}$ ( 1.5 INCHES)

FLOOR TEMP CELL 4 PROBE $\$ 3$

(NW) AT $5.0 \mathrm{CM}$ (2 INCHES)

(T79) 
ROW 15

COLUMN

1 FLOOR TEMP CELL $\$ 4$ PROBE \$3

(NW) AT $6.4 \mathrm{CM}$ (2.5 INCHES)

(T80)

2 FLOOR TEMP CELL * 4 PROBE \#3

3 FLOOR TEMP CELL \# 4 PROBE \#3

4 FLOOR TEMP CELL 4 PROBE $\$ 3$

5 FLOOR TEMP CELL \#4 PROBE *3

6 FLOOR TEMP CELL \#4 PROBE \#3

7 FLOOR TEMP CELL * 4 PROBE *3

8 FLOOR TEMP CELL 4 PROBE 3

(NW) AT $7.6 \mathrm{CM}$ (3 INCHES)

(T81)

(NW) AT $8.9 \mathrm{CM}(3.5$ INCHES $)$

(T82)

(NW) AT 10.2 CM (4 INCHES)

(T83)

(NW) AT $11.4 \mathrm{CM}$ (4.5 INCHES)

(T84)

(NW) AT $12.7 \mathrm{CM}(5$ INCHES)

(T85)

(NW) AT $14.0 \mathrm{CM}(5.5$ INCHES)

(T86)

(NW) AT 15.2 CM (6 INCHES)

(T87)

: : : : : : : : : : : : : : : : : : : : : : : : : : : : : : : : : : : : : : : : : : : : : : : : : : : : : : : : : : : : : : : : : : : : : : : :

COLUMN

1 FLOOR TEMP CELL 4 PROBE 3 (NW) AT 17.8 CM (7 INCHES)

2 FLOOR TEMP CELL $\$ 4$ PROBE $\$ 3$ (NW) AT 20.3 CM (8 INCHES)

3 FLOOR TEMP CELL 4 PROBE 3 (NW) AT 22.9 CM (9 INCHES)

4 FLOOR TEMP CELL 4 PROBE $\$ 3$ (NW) AT 25.4 CM ( 10 INCHES)

5 FLOOR TEMP CELL $\$ 4$ PROBE 3 (NW) AT 27.9 CM ( 11 INCHES)

6 FLOOR TEMP CELL 4 PROBE \#3 (NW) AT 30.5 CM (12 INCHES)

7 FLOOR TEMP CELL 4 PROBE $\$ 3$ (NW) AT 35.6 CM ( 14 INCHES)

8 FLOOR TEMP CELL 4 PROBE $\$ 3$ (NW) AT 40.6 CM (16 INCHES)

(T88)

(T89)

(T90)

(T91)

(T92)

(T93)

(T94)

(T95)

: : : : : : : : : : : : : : : : : : : : : : : : : : : : : : : : : : : : : : : : : : : : : : : : : : : : : : : : : : : : : : : : : : : : : : : : : : : : : : : :

COLUMN

1 FLOOR TEMP CELL 4 PROBE \#3 (NW) AT 45.7 CM ( 18 INCHES)

2 FLOOR TEMP CELL 4 PROBE 3 (NW) AT 55.9 CM (22 INCHES)

3 S FOUNDATION INSIDE TEMP CELL $\$ 4$ O CM BELOW SLAB

4 S FOUNDATION INSIDE TEMP CELL $410 \mathrm{CM}$ BELOW SLAB

5 S FOUNDATION INSIDE TEMP CELL $\$ 20$ CM BELOW SLAB

6 S FOUNDATION INSIDE TEMP CELL 431 CM BELOW SLAB

7 S FOUNDATION INSIDE TEMP CELL $\$ 441$ CM BELOW SLAB

8 S FOUNDATION INSIDE TEMP CELL 451 CM BELOW SLAB

(T96)

(T98)

(T101)

(T 102)

(T103)

(T104)

(T105)

(T106)

: : : : : : : : : : : : : : : : : : : : : : : : : : : : : : : : : : : : : : : : : : : : : : : : : : : : : : : : : : : : : : : : : : : : : : : : : : : : : : : : ROW 18

COLUMN

1 S FOUNDATION INSIDE TEMP CELL \$4 61 CM BF.LOW SLAB

2 S FOUNDATION OUTSIDE TEMP CELL 4 O CM BELOW SLAB

3 S FOUNDATION OUTSIDE TEMP CELL 420 CM BELOW SLAB

4 S FOUNDATION OUTSIDE TEMP CELL $\$ 441$ CM BELOW SLAB

5 S FOUNDATION OUTSIDE TEMP CELL $\$ 461$ CM BELOW SLAB

6 S FNDTN INSULATION OUTER SURF TEMP CELL 40 CM BELOW SLAB

7 S FNDTN INSULATION OUTER SURF TEMP CELL $\$ 410$ CM BELOW SLAB

8 S FNDTN INSULATION OUTER SURF TEMP CELL $\$ 420$ CM BELOW SLAB

(T107)

(T108)

(T109)

(T110)

(T111)

(T112)

(T113)

(T114)

: : : : : : : : : : : : : : : : : : : : : : : : : : : : : : : : : : : : : : : : : : : : : : : : : : : : : : : : : : : : : : : : : : : : : : : : : : : : : : : : ROW 19

COLUMN

1 S FNDTN INSULATION OUTER SURF TEMP CELL $\$ 31$ CM BELOW SLAB

(T115)

2 S FNDTN INSULATION OUTER SURF TEMP CELL $\$ 41$ CM BELOW SLAB

( $(1116)$

3 S FNDTN INSULATION OUTER SURF TEMP CELL $\$ 451$ CM BELOW SLAB

( $(117)$

4 S FNDTN INSULATION OUTER SURF TEMP CELL 461 CM BELOW SLAB

( $(118)$

5 E FOUNDATION INSIDE TEMP CELL $\$ 40$ CM BELOW SLAB

(T119)

6 E FOUNDATION INSIDE TEMP CELL $\$ 410$ CM BELOW SLAB

(T120)

E FOUNDATION INSIDE TEMP CELL 420 CM BELOW SLAB

(T121)

8 E FOUNDATION INSIDE TEMP CELL $\$ 431$ CM BELOW SLAB

(T 122)

: : : : : : : : : : : : : : : : : : : : : : : : : : : : : : : : : : : : : : : : : : : : : : : : : : : : : : : : : : : : : : : : : : : : : : : : : : : 
COLUMN

1 E FOUNDATION INSIDE TEMP CELL 441 CM BELOW SLAB

2 E FOUNDATION INSIDE TEMP CELL 451 CM BELOW SLAB (T124)

3 E FOUNDATION INSIDE TEMP CELL $\$ 41$ CM BELOW SLAB

4 E FOUNDATION OUTSIDE TEMP CELL 4 O CM BELOW SLAB

5 E FOUNDATION OUTSIDE TEMP CELL 420 CM BELOW SLAB (T127)

6 E FOUNDATION OUTSIDE TEMP CELL 441 CM BELOW SLAB

7 E FOUNDATION OUTSIDE TEMP CELL 461 CM BELOW SLAB

8 E FNDTN INSULATION OUTER SURF TEMP CELL 40 CM BELOW SLAB (T130)

: : : : : : : : : : : : : : : : : : : : : : : : : : : : : : : : : : : : : : : : : : : : : : : : : : : : : : : : : : : : : : : : : : : : : : : : : : : : : : : : ROW 21

COLUMN

1 E FNDTN INSULATION OUTER SURF TEMP CELL \$4 10 CM BELOW SLAB

2 E FNDTN INSULATION OUTER SURF TEMP CELL 420 CM BELOW SLAB

3 E FNDTN INSULATION OUTER SURE TEMP CELL 431 CM BELOW SLAB

4 E ENDTN INSULATION OUTER SURF TEMP CELL 441 CM BELOW SLAB

5 E FNDTN INSULATION OUTER SURF TEMP CELL 451 CM BELOW SLAB

6 E FNDTN INSULATION OUTER SURF TEMP CELL 461 CM BELOW SLAB

(T131)

(T132)

(T133)

(T134)

(T135)

(T136)

7 N FOUNDATION INSIDE TEMP CELL 4 O CM BELOW SLAB

(T137)

8 N FOUNDATION INSIDE TEMP CELL 410 CM BELOW SLAB

(T138)

: : : : : : : : : : : : : : : : : : : : : : : : : : : : : : : : : : : : : : : : : : : : : : : : : : : : : : : : : : : : : : : : : : : : : : : : : : :

COLUMN

1 N FOUNDATION INSIDE TEMP CELL 420 CM BELOW SLAB

2 N FOUNDATION INSIDE TEMP CELL 431 CM BELOW SLAB

(T139)

(T140)

3 N FOUNDATION INSIDE TEMP CELL $\$ 41$ CM BELOW SLAB

(T141)

$N$ FOUNDATION INSIDE TEMP CELL $\$ 451$ CM BELOW SLAB

( $(142)$

5 H FOUNDATION INSIDE TEMP CELL $\$ 61$ CM BELOW SLAB

(T143)

6 N FOUNDATION OUTSIDE TEMP CELL 4 O CM BFLOW SLAB

(T144)

$(\mathrm{T} 145)$

7 N FOUNDATION OUTSIDE TEMP CELL $\$ 20$ CM BELOW SLAB

(T146)

8 N FOUNDATION OUTSIDE TEMP CELL $\$ 441$ CM BELOW SLAB

ROW 23

COLUMN

1 N FOUNDATION OUTSIDE TEMP CELL 461 CM BELOW SLAB

2 N FNDTN INSULATION OUTER SURF TEMP CELL $40 \mathrm{CM}$ BELOW SLAB

3 N FNDTN INSULATION OUTER SURF TEMP CELL 410 CM BELOW SLAB

4 N FNDTN INSULATION OUTER SURF TEMP CELL 420 CM BELOW SLAB

5 N FNDTN INSULATION OUTER SURF TEMP CELL $\$ 31$ CM BELOW SLAB

6 N FNDTN INSULATION OUTER SURF TEMP CELL 441 CM BELOW SLAB

7 N FNDTN INSULATION OUTER SURF TEMP CELL 451 CM BELOW SLAB

(T147)

(T148)

(T149)

(T150)

(T151)

(T152)

(T153)

8 N FNDTN INSULATION OUTER SURF TEMP CELL $\$ 461$ CM BELOW SLAB

(T154)

: : : : : : : : : : : : : : : : : : : : : : : : : : : : : : : : : : : : : : : : : : : : : : : : : : : : : : : : : : : : : : : : : : : : : : : : : : : : : : :

ROW 24

COLUMN

1 STRGE WALL SURF TEMP 69 CM W OF CENTER LINE 203 CM FRM FLOOR

2 STRGE WALL SURF TEMP 69 CM W OF CENTER LINE 122 CM FRM FLOOR

3 STRGE WALL SURF TEMP 69 CM W OF CENTER LINE 41 CM FRM FLOOR

4 STRGE WALL SURF TEMP ON CENTER LINE 203 CM FRM FLOOR

5 STRGE WALL SURF TEMP ON CENTER LINE 122 CM FRM FLOOR

6 STRGE WALL SURF TEMP ON CENTER LINE 41 CM FRM FLOOR

7 STRGE WALL SURF TEMP 69 CM E OF CENTER LINE 203 CM FRM FLOOR

8 STRGE WALL SURF TEMP 69 CM E OF CENTER LINE 122 CM FRM FLOOR 
COLUMN

1 STRGE WALL SURF TEMP 69 CM E OF CENTER LINE 41 CM FRM FLOOR (T163)

2 STRGE WALL PROBE 0.32 CM FROM INNER SURFACE

$\begin{array}{llll}3 & \text { STRGE WALL PROBE } & 2.22 & \text { CM FROM INNER SURFACE } \\ 4 & \text { STRGE WALL PROBE } & 6.03 & \text { CM FROM INNER SURFACE }\end{array}$

(T164)

(T 165)

4 STRGE WALL PROBE 6.03 CM FROM INNER SURFACE

(T166)

(T167)

STRGE WALL PROBE 13.65 CM FROM INNER SURFACE

(T168)

(T169)

STRGE WALL PROBE 17.46 CM FROM INNER SURFACE

( 1 170)

8 STRGE WALL PROBE 19.05 CM FROM INNER SURFACE

ROW 26

COLUMN

1 AIR TEMP CELL 4275 CM FROM SOUTH WALL 10 CM FROM FLOOR

2 AIR TEMP CELL 4275 CM FROM SOUTH WALL 20 CM FROM FLOOR

3 AIR TEMP CELL 4275 CM FROM SOUTH WALL 30 CM FROM FLOOR

4 AIR TEMP CELL 4275 CM FROM SOUTH WALL 76 CM FROM FLOOR

5 AIR TEMP CELL $\$ 275$ CM FROM SOUTH WALL 122 CM FROM FLOOR

6 AIR TEMP CELL 4275 CM FROM SOUTH HALL 168 CM FROM FLOOR

7 AIR TEMP CELL 4275 CM FROM SOUTH WALL 213 CM FROM FLOOR

8 AIR TEMP CELL 4275 CM FROM SOUTH WALL 224 CM FROM FLOOR

(T171)

(T172)

(T173)

(T174)

( $\mathrm{T} 175)$

( $(176)$

(T177)

(T 178)

: : : : : : : : : : : : : : : : : : : : : : : : : : : : : : : : : : : : : : : : : : : : : : : : : : : : : : : : : : : : : : : : : : : : : : : : : : : : :

ROW 27

COLUMN

1 AIR TEMP CELL $\$ 275$ CM FROM SOUTH WALL 234 CM FROM FLOOR

2 AIR TEMP CELL $\$ 580$ CM FROM SOUTH WALL 10 CM FROM FLOOR

3 AIR TEMP CELL 4580 CM FROM SOUTH WALL 20 CM FROM FLOOR

4 AIR TEMP CELL 4580 CM FROM SOUTH WALL $30 \mathrm{CM}$ FROM FLOOR

5 AIR TEMP CELL 4580 CM FROM SOUTH WALL 79 CM FROM FLOOR

6 AIR TEMP CELL 4580 CM FROM SOUTH WALL 127 CM FROM FLOOR

7 AIR TEMP CELL \$4 580 CM FROM SOUTH WALL 175 CM FROM FLOOR

8 AIR TEMP CELL $\$ 580$ CM FROM SOUTH WALL 224 CM FROM FLOOR

$(T 179)$

(T180)

(T181)

$(T 182)$

(T183)

(T184)

( $(185)$

(T186)

: : : : : : : : : : : : : : : : : : : : : : : : : : : : : : : : : : : : : : : : : : : : : : : : : : : : : : : : : : : : : : : : : : : : : : : : : : : : : : : ROW 28

COLUMN

1 AIR TEMP CELL $\$ 580$ CM FROM SOUTH WALL 272 CM FROM FLOOR

2 AIR TEMP CELL 4580 CM FROM SOUTH WALL 320 CM FROM FLOOR

(T187)

(T188)

AIR TEMP CELL 4580 CM FROM SOUTH WALL 368 CM FROM FLOOR

(T 189)

BLACK GLOBE TEMP CELL 4152 CM FRM S WALL 152 CM FRM FLOOR

(T190)

BLACK GLOBE TEMP CELL $\$ 4472$ CM FRM S WALL 152 CM FRM FLOOR

(T191)

BLACK GLOBE TEMP CELL 4700 CM FRM S WALL 152 CM FRM FLOOR

(T192)

7 AIR TEMP CELL $\$ 3$ (5 PT AVER 3 OF N STRING \& 2 OF S STRING)

N STRING 326 CM FRM FLOOR 66 CM FRM E WALL 579 CM FRM S WAL

(T193)

187 CM FRM FLOOR 66 CM FRM E WALL 579 CM FRM S WAL

74 CM FRM FLOOR 66 CM FRM E WALL 579 CM FRM S WAL

8 AIR TEMP CELL $\$ 415$ CM FROM CLRSTY 30 CM FROM ROOF PEAK

(T194)

: : : : : : : : : : : : : : : : : : : : : : : : : : : : : : : : : : : : : : : : : : : : : : : : : : : : : : : : : : : : : : : : : : : : : : : : : : : : : : : 
ROW 29

COLUMN

1 AIR TEMP CELL $\$ 415 \mathrm{CM}$ FROM CLRSTY $20 \mathrm{CM}$ FROM ROOF PEAK

(T195)

AIR TEMP CELL $\$ 415$ CM FROM CLRSTY 10 CM EROM ROOF PEAK

(T196)

(T197)

EAST WALL OUTER SURF TEMP CELL \$ 4 SOUTH SECTION

(T198)

EAST WALL OUTER SURF TEMP CELL 4 NORTH SECTION

(T199)

5 NORTH WALL OUTER SURF TEMP CELL \$4

6 AIR TEMP CELL $\$ 3$ N SECT 275 CM FRM FLOOR 66 CM FRM E WALL 589 CM FROM SOUTH WALL

7 AIR TEMP CELL $\$ 3 \mathrm{~N}$ SECT 49 CM FRM FLOOR 66 CM FRME WALL

(T251) 589 CM FROM SOUTH WALL

(T252)

(T253)

8 SURF TEMP OF HEAT FLUX SENSOR $\$ 222$

$:::::::$ :

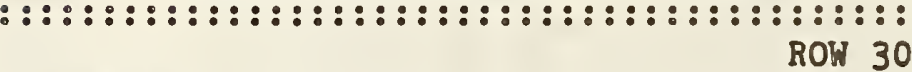

COLUMN

1 SURF TEMP OF HEAT FLUX SENSOR \$220

2 SURF TEMP OF HEAT FLUX SENSOR \$221

(T254)

(T255)

SURF TEMP OF HEAT FLUX SENSOR \$227

(T256)

SURF TEMP OF HEAT FLUX SENSOR \$228

(T257)

SURF TEMP OF HEAT FLUX SENSOR 226

(T258)

(T259)

SURF TEMP OF HEAT FLUX SENSOR \$225

(T260)

SURF TEMP OF HEAT FLUX SENSOR \$223

(T261)

8 SURF TEMP OF HEAT FLUX SENSOR $\$ 224$

ROW 31

COLUMN

1 SURF TEMP OF HEAT FLUX SENSOR \$229

(T262)

SURF TEMP OF HEAT FLUX SENSOR \#230

(T264)

HEATER DISCHARGE TEMP, CELL $\$ 4$

(T265)

4 PINK GLOBE TEMP CELL $\$ 4472$ CM FR S WALL 152 CM FR FLOOR
5 PINK GLOBE TEMP CELL $\$ 4$ I52 CM FR S WALL 152 CM FR FLOOR

(T512)

(T513)

6 OUTSIDE TEMP - MECH ASPIRATED- SOUTH

(T514)

(T515)

8 BLACK GLOBE TEMP CELL 4580 CM FR S WALL 152 CM FR FLOOR

(T516)

: : : : : : : : : : : : : : : : : : : : : : : : : : : : : : : : : : : : : : : : : : : : : : : : : : : : : : : : : : : : : : : : : : : : : : : : : : : : : : : : :

COLUMN

ROW 32

1 BLACK GLOBE TEMP CELL 4275 CM FR S WALL 152 CM FR FLOOR

(T517)

2 AIR TEMP CELL 4700 CM FROM S WALL 152 CM FROM FLOOR

(T518)

3 AIR TEMP CELL 4472 CM FROM S WALL 152 CM FROM FLOOR

(T519)

AIR TEMP CELL 4152 CM FROM S WALL 152 CM FROM FLOOR

(1520)

5 GROUND TEMP PROBE CELL \#2. 297 CM FROM BELOW FLOOR 391 CM FROM S WALL 144 CM FROM W WALL

(T277)

6 GROUND TEMP PROBE CELL \$2. 269 CM FROM BELOW FLOOR 391 CM FROM S WALL 144 CM FROM W WALL

(T278)

7 GROUND TEMP PROBE CELL \$2. 239 CM FROM BELOW FLOOR 391 CM FROM S WALL 144 CM FROM W WALL

(T279)

8 GROUND TEMP PROBE CELL $\$ 2.208$ CM FROM BFLOW FLOOR 391 CM FROM S WALL 144 CM FROM W WALL 
COLUMN

1 GROUND TEMP PROBE CELL $\$ 2.178$ CM FROM BELOW FLOOR 391 CM FROM SOUTH WALL 144 CM FROM W WALL

(T281)

2 GROUND TEMP PROBE CELL 2. 148 CM FROM BELOW FLOOR 391 CM FROM SOUTH WALL 144 CM FROM W WALL 391 CM FROM SOUTH WALL 144 CM FROM W WALL 391 CM FROM SOUTH WALL 144 CM FROM W WALL 391 CM FROM SOUTH WALL 144 CM FROM W WALL

7 GROUND TEMP PROBE CELL \#2, 35 CM ABOVE FLOOR 391 CM FROM SOUTH WALL 144 CM FROM W WALL

8 TROMBE WALL PROBE 1 PT. 1. 19.05 CM FROM INSIDE SURFACE

: : : : : : : : : : : : : : : : : : : : : : : : : : : : : : : : : : : : : : : : : : : : : : : : : : : : : : : : : : : : : : : : : : : : : : : : : : : : : : : :

COLUMN

1 TROMBE WALL PROBE 1 PT. 2. 17.46 CM FROM INSIDE SURFACE

2 TROMBE WALL PROBE 1 PT. 3. 13.65 CM FROM INSIDE SURFACE

3 TROMBE WALL PROBE 1 PT. 4. 9.84 CM FROM INSIDE SURFACE

4 TROMBE WALL PROBE 1 PT. 5. 6.03 CM FROM INSIDE SURFACE

5 TROMBE WALL PROBE 1 PT. 6.3 .22 CM FROM INSIDE SURFACE

6 TROMBE WALL PROBE 1 PT. 7. 0.32 CM FROM INSIDE SURFACE

7 TROMBE WALL PROBE 2 PT. 1. 19.05 CM FROM INSIDE SURFACE

8 TROMBE WALL PROBE 2 PT. 2. 17.46 CM FROM INSIDE SURFACE

(T289)

(T290)

(T291)

(T292)

(T293)

(T294)

(T295)

(T296)

: : : : : : : : : : : : : : : : : : : : : : : : : : : : : : : : : : : : : : : : : : : : : : : : : : : : : : : : : : : : : : : : : : : : : : : : : : : : : : : :

ROW 35

COLUMN

1 TROMBE WALL PROBE 2 PT. 3.13 .65 CM FROM INSIDE SURFACE

2 TROMBE WALL PROBE 2 PT. 4. 9.84 CM FROM INSIDE SURFACE

3 TROMBE WALL PROBE 2 PT. 5. 6.03 CM FROM INSIDE SURFACE

4 TROMBE WALL PROBE 2 PT. 6.2 .22 CM FROM INSIDE SURFACE

5 TROMBE WALL PROBE 2 PT. 7. 0.32 CM FROM INSIDE SURFACE

6 TROMBE WALL PROBE 3 PT. 1. 19.05 CM FROM INSIDE SURFACE

7 TROMBE WALL PROBE 3 PT. 2. 17.46 CM FROM INSIDE SURFACE

8 TROMBE WALL PROBE 3 PT. 3. 13.65 CM FROM INSIDE SURFACE

(T297)

(T298)

(T299)

(T300)

(T301)

(T302)

(T303)

(T304)

: : : : : : : : : : : : : : : : : : : : : : : : : : : : : : : : : : : : : : : : : : : : : : : : : : : : : : : : : : : : : : : : : : : : : : : : : : : : : : : ROW 36

COLUMN

1 TROMBE WALL PROBE 3 PT. 4. 9.84 CM FROM INSIDE SURFACE TROMBE WALL PROBE 3 PT. 5. 6.03 CM FROM INSIDE SURFACE TROMBE WALL PROBE 3 PT. 6. 2.22 CM FROM INSIDE SURFACE TROMBE WALL PROBE 3 PT. 7.0 .32 CM FROM INSIDE SURFACE TROMBE WALL PROBE 4 PT. 1.19 .05 CM FROM INSIDE SURFACE TROMBE WALL PROBE 4 PT. 2. 17.46 CM FROM INSIDE SURFACE TROMBE WALL PROBE 4 PT. 3. 13.56 CM FROM INSIDE SURFACE TROMBE WALL PROBE 4 PT. 4.9 .84 CM FROM INSIDE SURFACE 
COLUMN

1 TROMBE WALL PROBE 4 PT. 5. 6.03 CM EROM INSIDE SURFACE

2 TROMBE WALL PROBE 4 PT. 6.2 .22 CM FROM INSIDE SURPACE

(T313)

(T314)

(T315)

3 TROMBE WALL PROBE $4 \mathrm{PT}, 7.0 .32$ CM FROM INSIDE SUREACE

(T316)

TROMBE WALL PROBE 5 PT. 1.19 .05 CM FROM INSIDE SURFACE

(T317)

TROMBE WALL PROBE 5 PT. 2. 17.46 CM FROM INSIDE SURFACE

(T318)

TROMBE WALL PROBE 5 PT. 3. 13.65 CM FROM INSIDE SURFACE

(T319;

TROMBE WALL PROBE 5 PT. 4.9 .84 CM FROM INSIDE SURFACE

(T320)

8 TROMBE WALL PROBE 5 PT. 5. 6.03 CM FROM INSIDE SURFACE

: : : : : : : : : : : : : : : : : : : : : : : : : : : : : : : : : : : : : : : : : : : : : : : : : : : : : : : : : : : : : : : : : : : : : : : : : : : : : :

ROW 38

COLUMN

1 TROMBE WALL PROBE 5 PT. 6.2 .22 CM FROM INSIDE SURFACE TROMBE WALL PROBE 5 PT. 7. 0.32 CM FROM INSIDE SURFACE

- TROMBE WALL PROBE 6 PT. 1. 19.05 CM FROM INSIDE SURFACE TROMBE WALL PROBE 6 PT. 2. 17.46 CM FROM INSIDE SURFACE TROMBE WALL PROBE 6 PT. 3. 13.65 CM FROM INSIDE SURFACE TROMBE WALL PROBE 6 PT. 4.9 .84 CM FROM INSIDE SURFACE TROMBE WALL PROBE 6 PT. 5. 6.03 CM FROM INSIDE SURFACE TROMBE WALL PROBE 6 PT. 6.2 .22 CM FROM INSIDE SURFACE

(T321)

(T322)

(T323)

(T324)

(T325)

(T326)

(T327)

(T328)

: : : : : : : : : : : : : : : : : : : : : : : : : : : : : : : : : : : : : : : : : : : : : : : : : : : : : : : : : : : : : : : : : : : : : : : : : : : : :

COLUMN

1 TROMBE WALL PROBE 6 PT. 7. 0.32 CM FROM INSIDE SURFACE

ROW 39

2 TROMBE WALL PROBE 7 PT. 1. 19.05 CM FROM INSIDE SURFACE

(T329)

(T330)

TROMBE WALL PROBE 7 PT. 2. 17.46 CM FROM INSIDE SURFACE

(T331)

TROMBE WALL PROBE 7 PT. 3. 13.65 CM FROM INSIDE SURFACE

(T332)

(T333)

- TROMBE WALL PROBE 7 PT. 4.9 .84 CM FROM INSIDE SURFACE

(T334)

TROMBE WALL PROBE 7 PT. 5. 6.03 CM FROM INSIDE SURFACE

(T335)

7 TROMBE WALL PROBE 7 PT. 6. 2.22 CM FROM INSIDE SURFACE

(1336)

8 TROMBE WALL PROBE 7 PT. 7.0 .32 CM FROM INSIDE SURFACE

: : : : : : : : : : : : : : : : : : : : : : : : : : : : : : : : : : : : : : : : : : : : : : : : : : : : : : : : : : : : : : : : : : : : : : : : : : : : : : : :

COLUMN

1 TROMBE WALL PROBE 8 PT. 1. 19.05 CM FROM INSIDE SURFACE ROW 40

2 TROMBE WALL PROBE 8 PT. 2. 17.46 CM FROM INSIDE SURFACE

TROMBE WALL PROBE 8 PT. 3. 13.65 CM FROM INSIDE SURFACE

TROMBE WALL PROBE 8 PT. 4. 9.84 CM FROM INSIDE SURFACE

(T339)

(T340)

TROMBE WALL PROBE 8 PT. 5.6 .03 CM FROM INSIDE SURFACE

(T341)

TROMBE WALL PROBE 8 PT. 6.2 .22 CM FROM INSIDE SURFACE

(T342)

7 TROMBE WALL PROBE 8 PT. 7. 0.32 CM FROM INSIDE SURFACE
8 TROMBE WALL PROBE 9 PT. 1. I9.05 CM FROM INSIDE SURFACE

(T343)

(T344)

: : : : : : : : : : : : : : : : : : : : : : : : : : : : : : : : : : : : : : : : : : : : : : : : : : : : : : : : : : : : : : : : : : : : : : : : : : : : : : :

COLUMN

ROW 41

1 TROMBE WALL PROBE 9 PT. 2. 17.46 CM FROM INSIDE SURFACE

TROMBE WALL PROBE 9 PT. 3. 13.65 CM FROM INSIDE SURFACE

3 TROMBE WALL PROBE 9 PT. 4.9 .84 CM FROM INSIDE SURFACE

TROMBE WALL PROBE 9 PT. 5. 6.03 CM FROM INSIDE SURFACE

(T348)

- TROMBE WALL PROBE 9 PT. 6. 2.22 CM FROM INSIDE SURFACE

TROMBE WALL PROBE 9 PT. 7.0 .32 CM FROM INSIDE SURFACE

8 INSIDE GLAZING SURFACE TEMP 302 CM FROM EAST WALL 
COLUMN

1 INSIDE GLAZING SURFACE TEMP 180 CM FROM EAST WALL

( $\mathrm{T} 402)$

2 INSIDE GLAZING SURFACE TEMP 71 CM FROM EAST WALL

(T403)

OUTSIDE T-WALL SURFACE TEMP 302 CM FROM EAST WALL

(T404)

OUTSIDE T-WALL SURFACE TEMP 180 CM FROM EAST WALL

(T405)

OUTSIDE T-WALL SURFACE TEMP 71 CM EROM EAST WALL

(T406)

UPPER WEST SIDE VENT AIR TEMP IN TROMBE WALL

(T407)

LOWER WEST SIDE VENT AIR TEMP IN TROMBE WALL

(T408)

8 UPPER EAST SIDE VENT AIR TEMP IN TROMBE WALL

(T409)

: : : : : : : : : : : : : : : : : : : : : : : : : : : : : : : : : : : : : : : : : : : : : : : : : : : : : : : : : : : : : : : : : : : : : : : : : : : : : :

ROW 43

COLUMN

1 LOWER EAST SIDE VENT AIR TEMP IN TROMBE WALL

2 OUTSIDE AIR TEMP NORTH SIDE (MECH ASPIRATED SHIELD)

3 AIR TEMP CELL 2580 CM FROM S WALL 10 CM FROM FLOOR

4 AIR TEMP CELL $\$ 2580 \mathrm{CM}$ FROM S WALL $20 \mathrm{CM}$ FROM FLOOR

5 AIR TEMP CELL $2580 \mathrm{CM}$ FROM S WALL $30 \mathrm{CM}$ FROM FLOOR

6 AIR TEMP CELL $2580 \mathrm{CM}$ FROM S WALL $80 \mathrm{CM}$ FROM FLOOR

7 AIR TEMP CELL 2580 CM FROM S WALL 127 CM FROM FLOOR

8 AIR TEMP CELL $\$ 2580$ CM FROM S WALL 175 CM FROM FLOOR

(T410)

(T419)

$(T 412)$

(T413)

$(T 414)$

(T415)

(T416)

(T417)

: : : : : : : : : : : : : : : : : : : : : : : : : : : : : : : : : : : : : : : : : : : : : : : : : : : : : : : : : : : : : : : : : : : : : : : : : : : : : : : :

ROW 44

COLUMN

1 AIR TEMP CELL 2580 CM FROM S WALL 224 CM FROM FLOOR

2 AIR TEMP CELL $\$ 250$ CM FROM S WALL 272 CM FROM FLOOR

3 AIR TEMP CELL 2580 CM FROM S WALL 320 CM EROM FLOOR

4 AIR TEMP CELL 2580 CM EROM S WALL 368 CM FROM FLOOR

5 AIR TEMP CELL 2275 CM EROM S WALL 10 CM FROM FLOOR

6 AIR TEMP CELL 2275 CM EROM S WALL 20 CM FROM FLOOR

7 AIR TEMP CELL 2275 CM FROM S WALL 30 CM FROM FLOOR

8 AIR TEMP CELL $\$ 275$ CM FROM S WALL 76 CM EROM FLOOR

(T418)

(T419)

(T420)

(T421)

(T422)

(T423)

$(\mathrm{T} 424)$

( $\mathrm{T} 425)$

: : : : : : : : : : : : : : : : : : : : : : : : : : : : : : : : : : : : : : : : : : : : : : : : : : : : : : : : : : : : : : : : : : : : : : : : : : : : : : : ROW 45

COLUMN

1 AIR TEMP CELL 2275 CM FROM S WALL 122 CM FROM FLOOR

( $(\mathrm{T} 426)$

(T427)

AIR TEMP CELL 2275 CM FROM S WALL 168 CM FROM FLOOR

(T428)

AIR TEMP CELL $\$ 2275$ CM FROM S WALL 213 CM FROM FLOOR

(T429)

AIR TEMP CELL 2275 CM FROM S WALL 224 CM FROM FLOOR

(T430)

AIR TEMP CELL $\$ 2275$ CM EROM S WALL 234 CM FROM FLOOR

(T431)

SLOPED CEIL TEMP 97 CM FROM CLRSTRY 122 CM W OF CENTER LINE

(T432)

- SLOPED CEIL TEMP 97 CM FROM CLRSTRY

ON CENTER LINE

(T433)

: : : : : : : : : : : : : : : : : : : : : : : : : : : : : : : : : : : : : : : : : : : : : : : : : : : : : : : : : : : : : : : : : : : : : : : : : : : : : : : :

ROW 46

COLUMN

SLOPED CEIL TEMP 290 CM FROM CLRSTRY 122 CM W OF CENTER LINE SLOPED CEIL TEMP 290 CM FROM CLRSTRY ON CENTER LINE

(T434)

(T435) SLOPED CEIL TEMP 290 CM FROM CLRSTRY 122 CM E OF CENTER LINE

( $\mathrm{T} 436)$ FLAT CEIL TEMP 122 CM FROM S WALL 122 CM W OF CENTER LINE

( $\mathrm{T} 437$ ) FLAT CEIL TEMP 122 CM FROM S WALL

ON CENTER LINE

FLAT CEIL TEMP 122 CM FROM S WALL 122 CM E OF CENTER LINE

(T438)

FLAT CEIL TEMP 366 CM FROM S WALL 122 CM W OF CENTER LINE

(T439)

(T440)

FLAT CEIL TEMP 366 CM FROM S WALL

ON CENTER LINE

(T441) 
1 FLAT CEIL TEMP 366 CM FROM S WALL 122 CM E OF CENTER LINE

2 FLOOR SURFACE TEMP 102 CM FROM S WALL 122 CM W OF CENTER LINE

3 FLOOR SURFACE TEMP 102 CM FROM S WALL ON CENTER LINE

4 FLOOR SURFACE TEMP 102 CM FROM S WALL 122 CM E OF CENTER LINE

5 FLOOR SURFACE TEMP 307 CM FROM S WALL 122 CM E OF CENTER LINE

6 FLOOR SURFACE TEMP 307 CM FROM S WALL ON CENTER LINE

7 FLOOR SURFACE TEMP 307 CM FROM S WALL 122 CM W OF CENTER LINE

8 FLOOR SURFACE TEMP 513 CM FROM S WALL 122 CM W OF CENTER LINE

(T442)

(T443)

(T444)

(T445)

(T446)

(T447)

(T448)

(T449)

: : : : : : : : : : : : : : : : : : : : : : : : : : : : : : : : : : : : : : : : : : : : : : : : : : : : : : : : : : : : : : : : : : : : : : : : : : : : : :

COLUMN

1 FLOOR SURFACE TEMP 513 CM FROM S WALL ON CENTER LINE

2 FLOOR SURFACE TEMP 513 CM FROM S WALL 122 CM E OF CENTER LINE

3 FLOOR SURFACE TEMP 719 CM FROM S WALL 122 CM W OF CENTER LINE

4 FLOOR SURFACE TEMP 719 CM FROM S WALL ON CENTER LINE

5 FLOOR SURFACE TEMP 719 CM FROM S WALL 122 CM E OF CENTER LINE

6 BLACK GLOBE TEMP CELL $\$ 2152$ CM FRM S WALL 152 CM FRM FLOOR

7 BLACK GLOBE TEMP CELL $\$ 2472$ CM FRM S WALL 152 CM FRM FLOOR

8 BLACK GLOBE TEMP CELL $\$ 2700$ CM FRM S WALL 152 CM FRM FLOOR

(T450)

(T451)

(T452)

(T453)

(T454)

(T455)

(T456)

(T457)

: : : : : : : : : : : : : : : : : : : : : : : : : : : : : : : : : : : : : : : : : : : : : : : : : : : : : : : : : : : : : : : : : : : : : : : : : : : : : : : :

COLUMN

1 OUTSIDE AIR TEMP SOUTH SIDE (MECH ASPIRATED SHIELD)

(T458)

T-WALL INSIDE SURF TEMP 20 CM FRM E WALL 211.0 CM FRM FLOOR

3 T-WALL INSIDE SURF TEMP 20 CM FRM E WALL 124.5 CM FRM FLOOR

4 T-WALL INSIDE SURF TEMP 20 CM FRM E WALL 23.0 CM FRM FLOOR

5 T-WALL INSIDE SURF TEMP 180 CM FRM E WALL 211.0 CM FRM FLOOR

6 T-WALL INSIDE SURF TEMP 180 CM FRM E WALL 124.5 CM FRM FLOOR

7 T-WALL INSIDE SURF TEMP 180 CM FRM E WALL 23.0 CM FRM FLOOR

8 T-WALL INSIDE SURF TEMP 353 CM FRM E WALL 211.0 CM FRM FLOOR

(T459)

(T460)

(T461)

(T462)

(T463)

$(T 464)$

(T465)

: : : : : : : : : : : : : : : : : : : : : : : : : : : : : : : : : : : : : : : : : : : : : : : : : : : : : : : : : : : : : : : : : : : : : : : : : : : : : : : :

COLUMN

ROW 50

1 T-WALL INSIDE SURF TEMP 353 CM FRM E WALL 124.5 CM FRM FLOOR

2 T-WALL INSIDE SURF TEMP 353 CM FRM E WALL 23.0 CM FRM FLOOR

3 E WALL CELL 2 SURF TEMP 163 CM FRM S WALL 120 CM FRM FLOOR

4 E WALL CELL 2 SURF TEMP 582 CM FRM S WALL 310 CM FRM FLOOR

5 E WALL CELL 2 SURF TEMP 582 CM FRM S WALL 132 CM FRM FLOOR

6 N WALL CELL 2 SURF TEMP 96.5 CM FR E WALL 206 CM FRM FLOOR

7 N WALL CELL 2 SURF TEMP 96.5 CM FR E WALL 120 CM FRM FLOOR

(T466)

(T467)

(T468)

(T469)

$(\mathrm{T} 470)$

(T471)

(T472)

8 N WALL CELL $\$ 2$ SURF TEMP 290.0 CM FR E WALL 218 CM FRM FLOOR

(T473)

: : : : : : : : : : : : : : : : : : : : : : : : : : : : : : : : : : : : : : : : : : : : : : : : : : : : : : : : : : : : : : : : : : : : : : : : : : : : : : : :

COLUMN

ROW 51

1 W WALL CELL $\$ 2$ SURF TEMP 187 CM FRM S WALL 160 CM FRM FLOOR

$(T 474)$

(T475)

W WALL CELL 2 SURF TEMP 582 CM FRM S WALL 305 CM FRM FLOOR

( $(476)$

3 FLOOR SURF TEMP CELL $\$ 3.7 .61$ CM FR N WALL ON CENTER LINE

(T477)

FLOOR SURF TEMP CELL \$3. 15.24 CM FR N WALL ON CENTER LINE

(T478)

5 FLOOR SURF TEMP CELL \$3. 30.48 CM FR N WALL ON CENTER LINE

(T479)

FLOOR SURF TEMP CELL \$3. 60.96 CM FR N WALL ON CENTER LINE

(T480)

7 FLOOR SURF TEMP CELL 3. 101 CM FR N WALL ON CENTER LINE

(T481)

: : : : : : : : : : : : : : : : : : : : : : : : : : : : : : : : : : : : : : : : : : : : : : : : : : : : : : : : : : : : : : : : : : : : : : : : : : : : : 
COLUMN

1 FLOOR SURF TEMP CELL \$3. 513 CM FR N WALL ON CENTER LINE

2 FLOOR SURF TEMP CELL $\$ 3,104$ CM FR S WALL ON CENTER LINE

$(\mathrm{T} 482)$

(T483)

FLOOR SURF TEMP CELL 3. 61 CM FR S WALL ON CENTER LINE

(T484)

FLOOR SURF TEMP CELL 3 . 30.5 CM FR S WALL ON CENTER LINE

(T485)

FLOOR SURF TEMP CELL \#3. 15.5 CM FR S WALL ON CENTER LINE

$(T 486)$

FLOOR SURF TEMP CELL \$3. 7.6 CM FR S WALL ON CENTER LINE

(T487)

7 FLOOR SURF TEMP CELL $\$ 3.101 .6$ CM FR NORTH WALL

122 CM EAST OF CENTER LINE

(T488)

8 FLOOR SURF TEMP CELL $\$ 3.317$ CM FR NORTH WALL

122 CM EAST OF CENTER LINE

( $\mathrm{T} 489)$

ROW 53

COLUMN

1 FLOOR SURF TEMP CELL \$3. 513 CM ER NORTH WALL 122 CM EAST OF CENTER LINE

(T490)

2 FLOOR SURF TEMP CELL $\$ 3,104$ CM FR SOUTH WALL 122 CM EAST OF CENTER LINE

(T491)

3 FLOOR SURF TEMP CELL \$3. 101 CM FR NORTH WALL 122 CM WEST OF CENTER LINE

(T492)

4 FLOOR SURF TEMP CELL \$3, 317 CM FR NORTH WALL 122 CM WEST OF CENTER LINE

(T493)

5 FLOOR SURF TEMP CELL $\$ 3.513$ CM FR NORTH WALL 122 CM WEST OF CENTER LINE

(T494)

6 FLOOR SURF TEMP CELL $\$ 3.102$ CM FR SOUTH WALL 122 CM WEST OF CENTER LINE

(T495)

7 WEST WALL SURF TEMP CELL 2,582 CM FR SOUTH WALL 125 CM ABOVE FLOOR

8 AIR TEMP CELL 2. 152 CM FR SOUTH WALL 152 CM ABOVE FLOOR NEAR SOUTH BLACR GLOBE

(T496)

(T497)

: : : : : : : : : : : : : : : : : : : : : : : : : : : : : : : : : : : : : : : : : : : : : : : : : : : : : : : : : : : : : : : : : : : : : : : : : : : : : : : :

COLUMN

ROW 54

1 AIR TEMP CELL 2. 472 CM FR SOUTH WALL 152 CM ABOVE FLOOR NEAR CENTER BLACK GLOBE

2 AIR TEMP CELL 2. 700 CM FR SOUTH WALL 152 CM ABOVE FLOOR NEAR NORTH BLACK GLOBE

(T498)

( $\mathrm{T} 499)$

(T500)

(T501)

(T502)

(T503)

(T504)

(T505)

ROW 55

COLUMN

1 OUTSIDE GROUND PROBE 117.5 CM BELOW GROUND

2 OUTSIDE GROUNDPROBE 87.3 CM BELOW GROUND

3 OUTSIDE GROUNDPROBE 56.5 CM BELOW GROUND

OUTSIDE GROUNDPROBE 26.5 CM BELOW GROUND

(T509)

OUTSIDE GROUND PROBE 4.4 CM ABOVE GROUND

(T510)

OUTSIDE GROUNDPROBE 35.0 CM ABOVE GROUND

(T511)

ENERGY USED BY THE FAN COIL UNIT IN CELL 2

ENERGY USED BY THE LIGHTS \& CUTLETS IN CELL 2 


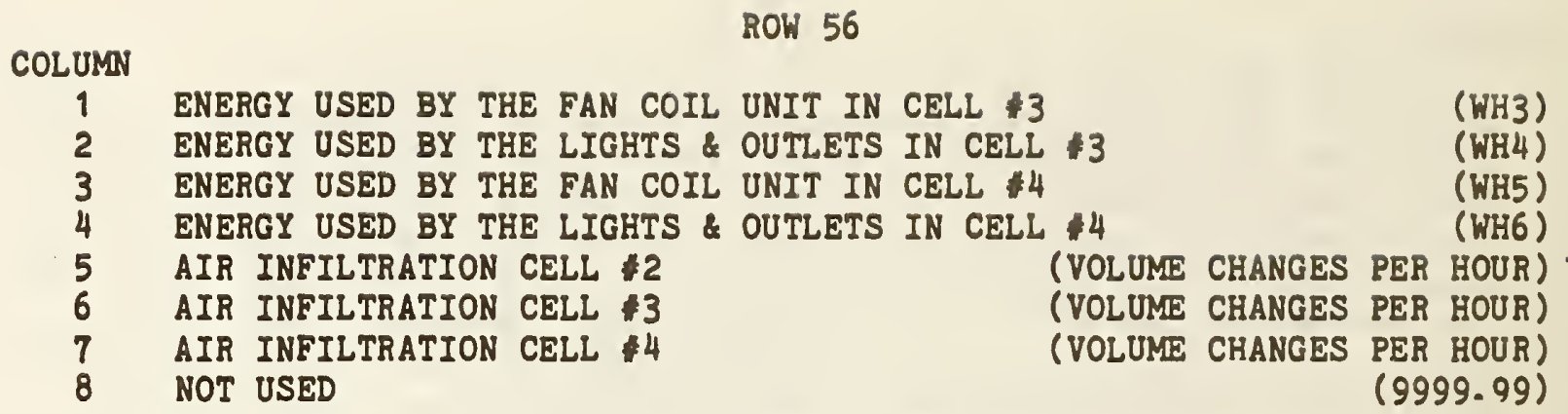

(VOLUME CHANGES PER HOUR) (VOLUME CHANGES PER HOUR) (VOLUME CHANGES PER HOUR) (9999.99) 
NBS. 1144 (REV. $2.8 C)$

\begin{tabular}{|c|c|c|}
\hline 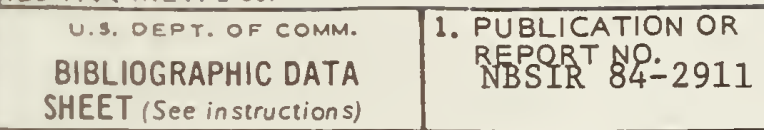 & 2. Performing Organ. Report No. & $\begin{array}{l}\text { 3. Publication Date } \\
\text { August } 1984\end{array}$ \\
\hline \multicolumn{3}{|c|}{$\begin{array}{l}\text { National Bureau of Standards Passive Solar Test Facility - Instrumentation and Site } \\
\text { Handbook }\end{array}$} \\
\hline \multicolumn{3}{|l|}{ 5. AUTHOR(S) } \\
\hline \multicolumn{2}{|c|}{$\begin{array}{l}\text { 6. PERFORMING ORGANIZATION (If joint or other than NBS, see instructions) } \\
\text { NATIONAL BUREAU OF STANDARDS } \\
\text { DEPARTMENT OF COMMERCE } \\
\text { WASHINGTON, D.C. } 20234\end{array}$} & 8. Type of Report \& Period Covered \\
\hline \multicolumn{3}{|l|}{$\begin{array}{l}\text { 9. SPONSORING ORGANIZATION NAME AND COMPL } \\
\text { U.S. Dept. of Energy } \\
\text { Office of Solar Heat Technologies } \\
\text { Forrestal Building } \\
\text { Washington, D.C. } 20585\end{array}$} \\
\hline
\end{tabular}

10. SUPPLEMENTARY NOTES

Document describes a computer program; SF-185, FIPS Software Summary, is attached.

1. ABSTRACT (A 200-word or less foctual summary of most significont informotion. If document includes a significant

bibliography or literature survey, mention it here)

The National Bureau of Standards (NBS), under the sponsorship of the U,S, Department of Energy (DoE) has constructed a passive solar test facility. As a part of the DoE's Experimental Systems Research Program, the NBS test facility has been constructed for the purpose of acquiring and distributing to participating researchers class A level performance data for different passive systems. These data are acquired for use in: detailed building energy analysis and model/algorithm validation; and performance characterization of passive subsystems.

This handbook provides a complete description of the test building, thermophysical properties of the building material, location of the sensors installed at the test facility, and data acquisition system and procedures.

12. KEY WORDS (Six to twelve entries; alphabetical order; capitalize only proper names; and seporate key words by semicolons) building, data acquisition, location; material; passive; property; sensor; solar; system test facility; thermophysical; wall section

13. AVAILABILITY

X Unlimited

For Official Distribution. Do Not Release to NTIS

Order From Superintendent of Documents, U.S. Government Printing Office, Washington. D.C. 20402.

14. NO. OF

PRINTED PAGES

88

15. Price

[X] Order From National Technical Information Service (NTIS), Springfield, VA, 22I6I 


